Historic, Archive Document

Do not assume content reflects current scientific knowledge, policies, or practices. 



\subsection{3}
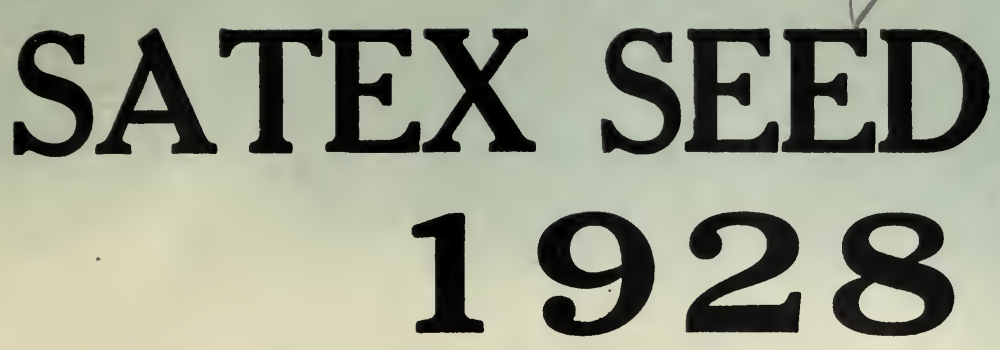

T I R F X EX X

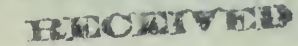
- FEB 181928 t

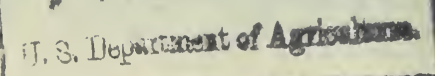

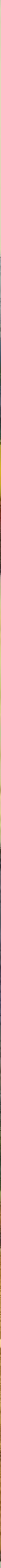

\section{SEED and POULTRY SUPPLY ANNUAL}




\section{$\mathbb{T H A N} \mathbb{K}$ !}

Before you turn the pages of this catalog we want to say that we are indeed thankful for the wonderful business that you have given us in the year which has made the year 1927 one of the best in the history of our company.

It is our constant endeavor to give you only such merchandise that will please you. In -each line we have selected only such merchandise which has proven its merits and carry a complete line of each in stock, which enables us to render you prompt service, filling all orders the same day received.

Our service and merchandise must be satisfactory to you. If it does not please you, will you kindly tell us?

Appreciating your continued patronage, we are

Respectfully yours,

\section{Satex SeEd Company.}

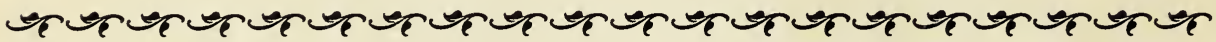

\section{POSTAGE CHARGES}

Heretofore we have listed all garden and flower seeds postpaid, which has not been fair to our customers who are in the state of Texas as we had to add enough to each item to take care of the postage on distant points from which we received orders, so this year we have listed all items f. o. b. San Antonio (except packages and ounces which are postpaid.) If you are close to San Antonio, this will illustrate the saving this means to you. For example, a variety of beans listed last year at 50c per pound postpaid is listed this year at $40 \mathrm{c}$ f. o. b. San Antonio. Your order for five pounds at the postpaid price amounts to $\$ 2.50$. Say you live in the second zone, five pounds cost you $\$ 2.00$ plus $13 \mathrm{c}$ postage, a saving to you of $37 c$ over last year's way of listing. If you are not positive of postage rate send sufficient money to cover same and we will refund the difference. Allow postage for one extra pound when ordering to take care of extra weight for wrapping packages.

Mexico Customers-Add $14 c$ per pound to prices, also $15 c$ for registration. We ship up to 20 lbs. per package into Mexico.

NON-WARRANTY-Note. There are many contingencies to be encountered in growing plants from seed and in setting out plants that are dependent on the weather and other conditions over which we have no control, that success in planting is not altogether dependent on the seed or plant. We send out only seed that have been tested for germination, and which we believe will produce the kind of variety and plant rpresented; but:

Satex Seed Company gives no warranty, express or implied, as to description, quality. productiveness or any other matter of any seeds, bulbs, plants or trees they send out and they will not be responsible in any way for the crop. If the purchaser does not accept the goods on these terms, they are at once to be returned. 


\section{HOW TO ORDER BY MAIL}

YOUR NAME AND ADDRESS-Be sure that your name and address in full are written very plainly. We have on file quite a few orders without any name and address, and if you should have mailed us an order and failed to receive same during the past year, kindly write us, giving approximate date of order and copy of order, and if on file, we will give same our attention. If you do not receive any goods ordered from us within ten days after the order is sent kindly Int us hear from you, and we can then avoid further delay. We fill all orders the day reryived, unless unable to supply same at the time, and will advise you accordingly, so do not uesitate to write us, if the goods do not show up.

CASH WITH ORDER-The proper way is to send remittance in full to cover order and postaze. We send orders C. O. D. only if 25 per cent of the amout of order.is enclosed. Plants are never sent C. O. D.

REMTTMANCES should be made by Postoffice or Express Money Order or Bank Draft. On -,rders up to One Dollar, we will accept clean unused postage stamps. If currency is sent, letter should be registered, and if local checks are sent they should be certified. We do not accept responsibility for orders, which-never reach us.

\section{PARCEL POST RATES AND RULES GOVERNING FORIVARDING OF SEEDS,} BULBS, PLANTS, POULTRY SUPPLIES.

DOMESTIC PARCEL POST RATES

On Seeds, Bulbs, Poultry Supplies, etc.,
Each Additional Pound or Fraction

\begin{tabular}{llll}
\hline FIRST ZONE-Within 50 miles of San Antonio............................ & $7 \mathrm{c}$ & $1 \mathrm{c}$ \\
\hline SECOND ZONE-Within 50 to 150 miles of San Antonio.............. & $7 \mathrm{c}$ & $1 \mathrm{c}$ \\
\hline THIRD ZONE-Within 150 to 300 miles of San Antonio ............ & $8 \mathrm{c}$ & 2c \\
\hline FOURTH ZONE-Within 300 to 600 miles of San Antonio .......... & $9 \mathrm{c}$ & $4 \mathrm{c}$ \\
\hline FIFTH ZONE-Within 600 to 1000 miles of San Antonio ............ & $10 \mathrm{c}$ & $6 \mathrm{c}$
\end{tabular}

WEIGHT LIMT-Packages are subject to a limit of maximum weight in the first, second and third zone of 70 pounds; in all other zones of 50 pounds.

ZONE RATES may be had by applying to your postmaster who will tell you which zone you are in, with reference to San Antonio, or consult parcel post schedule above.

POSTAGE has to be prepaid and customers will kindly add same to their valued orders, as packages cannot be mailed charges collect at destination. This refers to large quantities than prices quoted postpaid.

PARCEL POST, C. O. D.-Packages ruay be sent C. O. D. at an extra expense of $12 \mathrm{c}$, which amount is added to the order.

INSURED PARCEL POST-If customers want their packages sent insured they will kindly add cost to their remittance. Rate-Up to $\$ 5,5 \mathrm{c}$; up to $\$ 25,8 \mathrm{c}$.

\section{FREE - Seeds Or Poultry Supplies - FREE}

We want the names of five gardeners or poultry raisers. Send us your order for $\$ 1.00$ worth of garden or flower seeds and the names and addresses of five of your friends interested in gardening or poultry raising and we will send you absolutely free twenty-five cents worth of flower or garden seeds, your own selection or choice of any of the following premiums. This offer does not apply to order of Poultry Feeds, Remedies or Supplies, Garden Tools or plants. Orders must be strictly Garden or Flower Seeds.

\section{FREE OFFER WITH $\$ 1.00$ SEED ORDER;}

No. $1-25 \mathrm{c}$ Garden or Flower Seed Assortment.

No. 2-Star Fountain and Feeder

Page 31

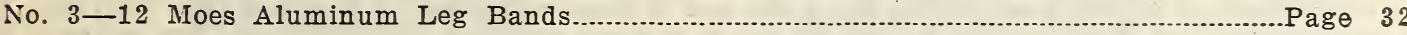

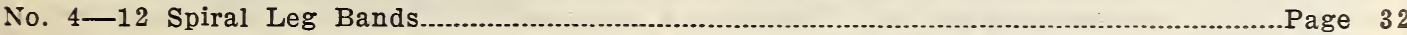

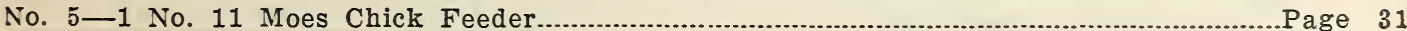




\section{ALPHABETICAL INDEX}

\begin{tabular}{|c|c|c|}
\hline Alfalfa & Flower Pots & Poultry \\
\hline Antrol & Flower Seeds …................32_34 & Poultry Toe Punch \\
\hline rsenate of Lead & Flyrol & Poultry Remedies..41-43-45-46 \\
\hline vian Bacterin .................. 46 & Fungicides & Potatoes 26 \\
\hline Avicol & Garden Tools …........17-19 & Pratt's Poultry Regulator....43 \\
\hline 3aby Chicks …...................... & Gladiola & Pumpkins \\
\hline arnes Worm Emulsion.......39 & Grasses $\quad . . . \ldots \ldots . . . .$. & Pruning Saw \\
\hline acili Kil B-K ......................... 46 & Grass Catchers & Pyrethrum Flowers Ground 13 \\
\hline eans, Garden ….......... 4-6 & Grit Boxes ..................... & Radish \\
\hline eans, Soy ......................... & Hatching Egg Boxes ….......31 & Rakes \\
\hline Beets & Hess's Poultry Remed:es....43 & Rape \\
\hline Black Leaf " $40 "$..................... & Hoes …................ & Rat Poison \\
\hline Bordeaux Mixture …............9 9 & Hose, Rubber & $\operatorname{Rax}$ \\
\hline Brooders …............31-33-35-37 & Caps & Rutabaga \\
\hline utter Cartons & bators & 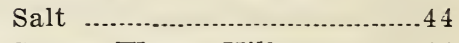 \\
\hline r Paper & Powder & Screw Worm Killer................44 \\
\hline rmilk Feeders .............25 & icides 9 & Seed Sower …....................... \\
\hline 3urrell-Dugger Remedies ..45 & ke's Roup Remedy & nesan ........ \\
\hline abbage & -.......... 14 & \\
\hline alcium Arsenate ..................9 & Knox-Out ................... & oing Coop ....................... \\
\hline Cantaloupe & $\ldots 14$ & vel \\
\hline anary Supplies …...............49 & 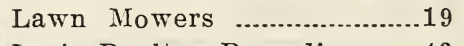 & Shot \\
\hline cbola & Lee's Poultry Remedies .......43 & rol \\
\hline lineum & Bands & Sodium Fluoride …...............13 \\
\hline arbon Bisulphide ..............44 & Gear's Poultry Remedies 41 & \\
\hline arrots & …....16 & hum .................... \\
\hline Cauliflower & 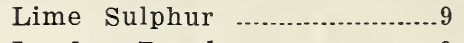 & ling Forks .. \\
\hline Celery & London I & Spinach \\
\hline hard, Swiss & Mangel Wurzel & Pumps ... \\
\hline hick Boxes .................. & Mash Hoppers & inklers \\
\hline Feeders …......23-25 & Nillet & Sprinkling Cans .................19 \\
\hline $\mathrm{rds}$ & ture Gauge. & ish \\
\hline onkey's Poultry Remedies 41 & $.16-18$ & Parasite Remover..... \\
\hline opper Sulphate …..................9 & $\ldots \ldots .16$ & (n) \\
\hline ras & $\ldots 29$ & F-Plant \\
\hline 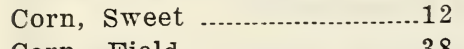 & omica & \\
\hline . & Okra & wer \\
\hline 12 & Onion Seed .. & erior Poultry Feeds.........48 \\
\hline 49 &. .20 & mometers \\
\hline og Remedies & $\ldots . . .44$ & acco Dust \\
\hline Founts & -.......9 & \\
\hline arriers & sley & $p$ Nest $F$ \\
\hline lant & 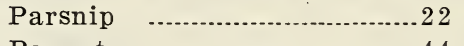 & - \\
\hline gg Tester .................................... & Peanuts & . \\
\hline adive & (2)...................... & Vigoro \\
\hline som Salts _............-.....47-49 & -........24 & $\ldots . . .47$ \\
\hline hrmogerm & ....22 & $. .18-20$ \\
\hline & -.....17 & $\ldots .17$ \\
\hline ish Oil Soap (n..................... 9 & Plow, Garden .............. & Whe Dallus …... \\
\hline lex-O-Glass $\quad$-.......................15 & Poultry Feed & Yard Egg Boxes \\
\hline
\end{tabular}

\section{A BOOKLET EVERY POULTRYMAN SHOULD HAVE}

A complete 72 page poultry book describing the proper way to raise chicks, how to build poultry houses, select layers and breeders, cure poultry diseases, etc., will be mailed to you free by writing direct to UNIVERSAL MILLS, Fort Worth, Texas. We will be glad to help you with your Poultry Problems. We maintain a Poultry Department headed by Mr. F. C. Wantzloeben, a poultryman of 15 years experience. Don't hesitate to write us. We are here to serve you. 


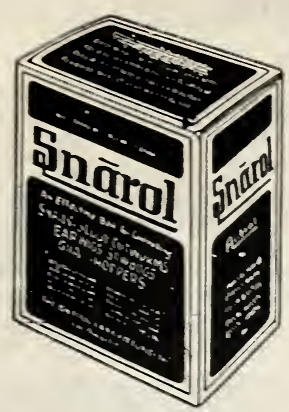

Kills Garden Pests Quick

\section{Stops Damage!}

New, scientific methed, death to cut worms, slags, snails, earwigs, sowbugs, grass-hoppers and other annoying pests.

Water doesn't harm it, and it doesn't harm the plants or regetation.

Good plants, seeds and bulbs are often ruined by the ravages of the above mentioned pests. Generally they do their work at nightwhile you sleep. They adrance on regetation and destroy the tender growth as they shoot out of the ground. Nearly everything with which they come in contact is thus destroyed.

Snarol is a scientifically prepared meal that you simply broadcast on the ground around the flowers and under the shrubs. The pest eats it as a food and is quickly exterminated. This modern pest control, unlike many others, is safe to use around pets or fowls.

Snarol is widely endorsed by leading nurseries, institutions and gardeners everywhere. It is easy to use and quick to effectively destroy the pest, which may be eating the tender shoots of your farorite flowers, regetables or plants. Use Snarol in the garden and you will be free from the ravages of these pests. Write us today for a supply, or free 24-page booklet on Pest Control, written by Mr. A. D. Cardinet, famous entomologist, and discorerer of Snarol.

\section{PRICES :}

1-1b. Carton

$\$ \quad .50$

3-1b. Carton

1.00

15-lb. Bag

3.75

100-lb. Bag 15.00

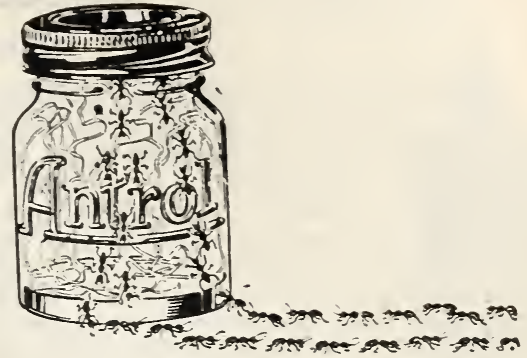

\section{Against Ants!}

"They Stand on Guard Like Sentinels." "Antrol Jars soon "Call a Halt on Ants."

For controlling Argentine and species of house ants commonly known as honey-dew loving ants

Antrol containers offer you three distinct adrantages over ordinary, old_time methods.

First, this modern system kills the queen ant and thus destroys the entire ant colony.

Second, Antrol is safe to use around children or pets.

And third, the Antrol method is in accordance with the methods adopted by the United States Gorernment.

These three adrantages of Antrol make it the most popular ant control on the market. Ants immediately smell the Antrol Syrup in the jars and eat it as a food. They climb into the jar through the openings provided for that purpose in the top of the containers, and down the tiny bits of excelsior which operate as "ladders" into the Syrup. The ants then carry this Syrup, which is mildly poisonous, back to the ant nest and in this way transmit it to the queens and their entire colony. Soon the entire ant colony is destroyed and your home is free from the ravages of these annoying pests.

Antrol jars, therefore, protect your home from ants effectively, safely and permanently. They stand on guard like sentinels! Write today for 24-page booklet on Pest Control, written by Mr. A. D. Cardinet, famous entomologist, and inventor of the Antrol system.

\section{PRICES:}

Antrol Cottage Sets (containing 9 jars and 6-oz. bottle of Syrup) …..... 1.90

Extra Jars (each) ......................................

Pint Bottles of Syrup .....................................

Quart Bottles of Syrup ...................................

Gallon cans of Syrup .......................... 4.00

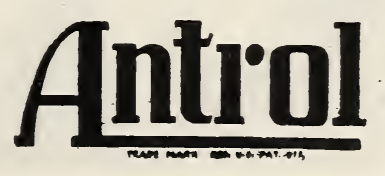

The National Ant Control

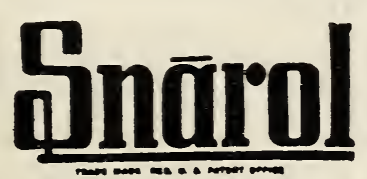

The National Pest Control 


\section{BUSH OR SNAP BEANS}

\section{GREEN PODDED VARIETIES}

Culture-For the earliest crop, plant just as soon as the weather gets warm, about the 15 th of March. For a succession, plant every two weeks throughout the summer until the last week in August. For field culture, plant in rows two feet apart, drill the beans three inches apart, covering about two inches. For home garden, the rows may be two feet apart. Cultivate them often until they have blossomed, not afterward, and never work them when the vines are wet. Two pounds will plant 120 feet; 60 lbs. will plant an acre. Spray the beans early and frequently with Bordeaux Mixture to free them of rust, blight, mildew and leaf spot.

Hopkins Improved Red Valentine-A very hardy, early and productive standard sort. Pods $4 \frac{1}{2}$ inches long, round and creaseback, medium green, slightly stringy and of good quality. Pkt., 10c; lb., 25c; 10 lbs., \$2.00; 100 lbs., \$17.50.

Black Valentine-Beautiful large pods about 6 inches long, slender, round and nearly straight, fine grained, dark green in color. Seed black. An early, productive, profitable gardeners variety. Plant more vigorous and productive than Red Valentine and pods darker green. Pkt., 10c; lb., 25c; 10 lbs., \$2.00; 100 lbs., \$17.50.

Stringless Green Pod-The pods are medium green, five to six inches long, cylindrical,

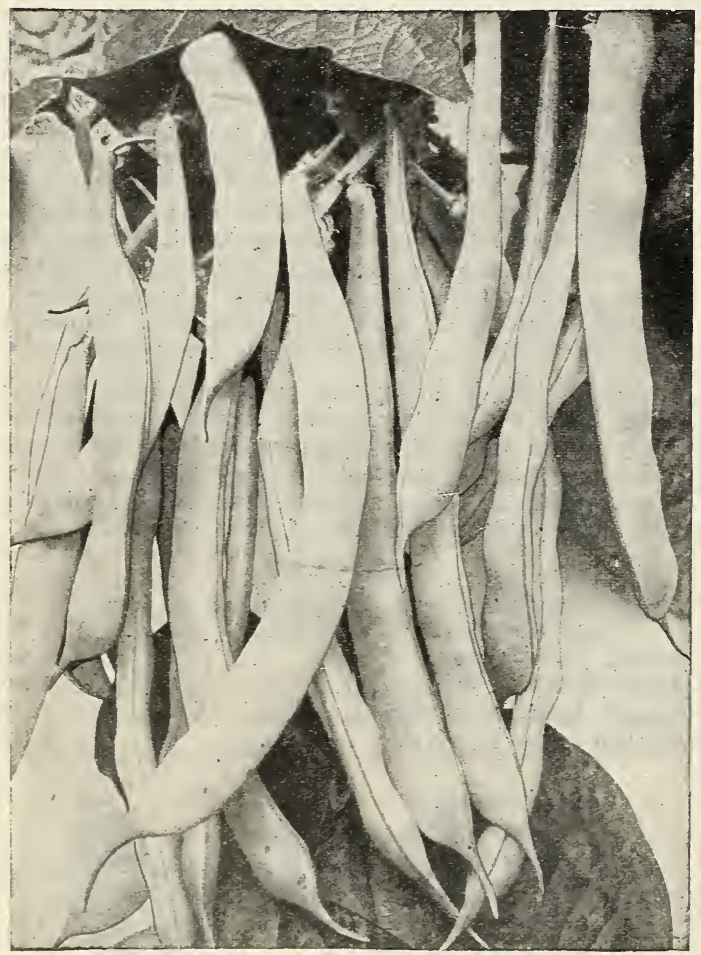

GOLDEN WAX larger than those of the Red Valentine, but not quite as fleshy, of equally high quality and remain crisp and tender longer. Absolutely stringless. Pkt., 10c; 1b., 25c; 10 lbs., \$2.25; 100 lbs., \$20.00.

Giant Stringless Green Pod-Another exceptionally fine bean for home or market, perfectly stringless; pods longer than Burpee's Stringless; strong, vigorous grower, and a continuous bearer of delicious beans for weeks. Pkt., 10c; 1b., 25c; 10 lbs., \$2.25; 100 lbs., \$20.00

Longfellow-Moderately early and productive. Pods dark green, 6 to 7 inches long, very slender, straight and round; very slightly stringy, tender, fine grained, attractive and of good quality. Pkt., 10c; 1b., 25c; 10 lbs., $\$ 2.00 ; 100$ lbs., \$17.50.

\section{BUSH WAX BEANS}

Improved Golden Wax-One of the best beans in cultivation. Pods are long, nearly straight, broad and flat, and golden yellow; seed white, more or less covered with two shades of purplish red. Pkt., 10c; 1b., 25c; 10 lbs., \$2.25.

Prolific Black Wax-Early; pods round, about five inches long, fleshy, brittle and stringless, deep yellow in color and attractive. A standard sort. Pkt., 10c; 1b., 25c; 10 lbs., \$2.25; 100 lbs., \$18.50.

Pencil Pod Wax-Early and very productive Pods large, 5 to 6 inches long, round, straight and creaseback, strictly stringless, free from fiber, fleshy and brittle; of highest quality; color very clear yellow. Pkt., 10c; lb., 25c; 10 lbs., \$2.25; 100 lbs., \$18.00.

Crystal White Wax-Pods small, about $3 \frac{1}{2}$ inches long, round and curved with crease in back, very fleshy and brittle. Color greenishwhite with silvery shade. Used mostly for canning. Pkt., 10c; lb., 35c; 10 lbs., \$3.00.

\section{POLE BEANS}

Culture-Pole beans should be planted in four-foot rows, three feet apart, six to seven beans in each hill. Pole can be set at time of planting or after they come up. The pole should not be less than five feet. They can also be planted in the cornfield and allowed to run up the stalk. One-half pound will plant fifty hills. Thirty-five pounds to the acre.

White Creaseback-A white-seeded round green-pod Pole Bean, a prolific yielder of excellent quality. Sometimes called White Cornfield Beans. Pkt., 10c; 1b., 25c; 10 lbs., \$2; 100 lbs., \$17.50.

Striped Creaseback-A hardy and very productive green podded cornfield bean. The vines are sturdy and of good climbing habit, with small-medium, deep green leaves. The pods are long, about 6 inches, very cylindrical or completely rounded. Large pkt. 10c; 1 lb., 25c; 10 lbs., $\$ 2.00 ; 100$ lbs., \$17.50. 


\section{FERTILIZERS--SEED INOCULATION}
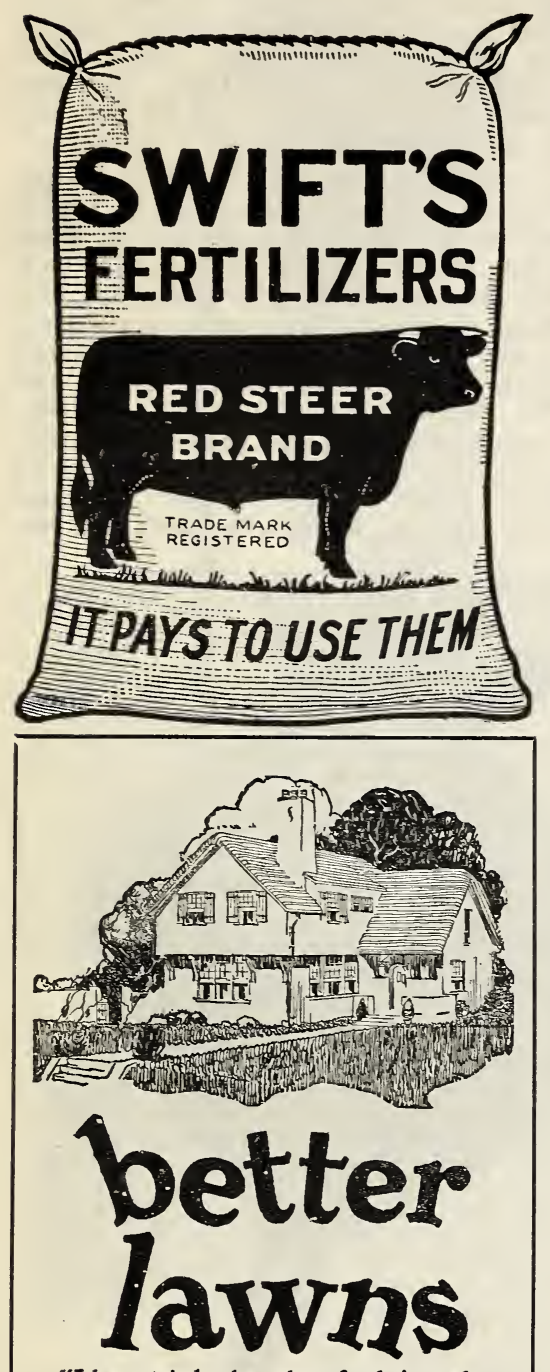

"I have tried other plant foods in mak. ing new lawns and rehabilitating old lawns," writes Mr. Floyd R. Murray, of Hammond, Indiana.

"No other plant food has given the results shown by Vigoro.

"Grass was up within nine days after planting!"

You can have equal success with Vigoro for lawns, flowers, gardens, shrubbery and trees.

Clean, odorless, easy to apply, it is not to be compared with any other plant food you have ever known. Its cost is remarkably low!

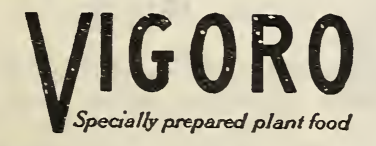

A Swift \& Company product

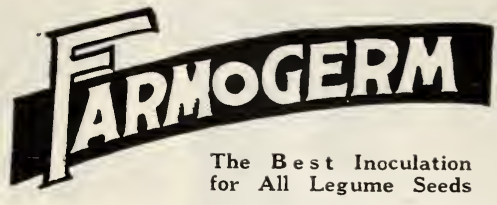

IVHAT FARMOGERM IS: A pure culture of nitrogen-fixing bacteria of highest quality. By reason of the patented stopper, which admits air and excludes contaminations, FARMOGERM is guaranteed for five years-always fresh-always strong

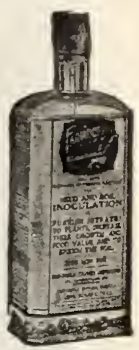

A Sensible Insurance and a Profitable Investment

We believe in inoculation, we favor the pure jelly medium, and we believe in FARMOGERM. We recommend that all legume seeds purchased from us be inoculated before planting.

(A different culture is required for each legume group, so, when ordering, be sure to state what crops you wish to inoculate.

NEW LOW PRICES For small seeds-Clovers, Alfalfa.

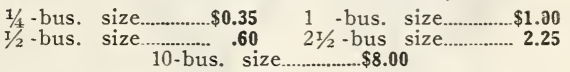

Special Reduced Prices on Cultures for Large-Size Seeds, Soy Beans, Cowpeas, Peas, Vetches, etc.

$$
1 / 2 \text {-bus. size.............\$0.35 1-bus. size............. } \$ 0.60
$$

Special Garden Size for Garden Peas, Beans, and Sweet Peas, 25 cts.

NOTE-Prices on all fertilizers are. subject to market changes. Write for quantity prices.

\section{SWIFT'S FERTILIZERS}

Acid Prosphate-16\%-It gives excellent results oif nearly all crops, but is especially recommended for use on grains and grasses. Lb., 4c; 100 lbs., \$1.75.

Bone Meal-Ground very fine. Acts very quickly. There is no better fertilizer for the home garden than this splendid material. Splendid for rose beds, pot plants, etc., Lb., 6c; 100 lbs., \$4.00.

Lime (Hydrated) - For the sweetening and renovating land that has become sour. It promotes growth and has a tendency to prevent weeds. Lb., 2c; 40 lbs., 50c.

Nitrate of Soda-A fertilizer very quick in action and used for the nitrogen it contains. Will mature a crop several weeks earlier and greatly improves it. Lb., 10c; 100 lbs., \$4.50.

Swift's 12.4-4-For fruit trees and small fruits, garden truck, etc. Quick in starting, lasting in effect, etc. Quick in healthy growth and developing the fruit, fine for all root crops. Lb., 5c; 100 lbs., \$3.00.

Swift's 10-4-7-This brand has been especially prepared for such crops as require a quick, strong fertilizer, should be well mixed into the soil, suitable for all garden truck especially strawberries and watermelons. Lb., 5c; 100 lbs., \$3.25.

Muriate of Potash-To be used liberally, especially for root crops. Lb., 5c; 100 lbs., \$3.50.

Vigoro-A highly concentrated commercial fertilizer specially blended for the home gardener for lawns, gardens, flowers, shrubbery and trees. 5 lb. pkg., 50c; 25 lbs., \$1.50; 50 lbs., \$2.75; 100 lbs., \$5.00.

Vitamite-A bacterial culture that is bereficial to all plant life. Improves the growth of all common types of garden vegetables and flowers. $75 \mathrm{c}$ shipping weight, 21/4 lbs. 


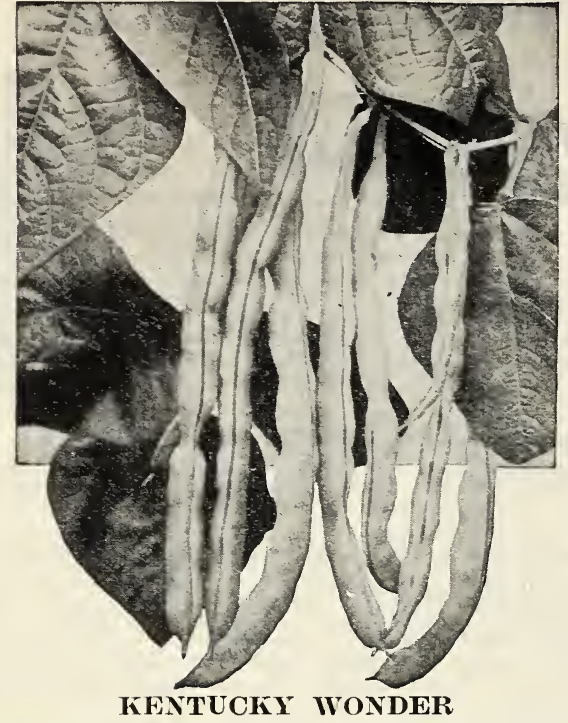

Kentucky Wonder-An excellent greenpodded variety; enormously productive, the long pods hanging in great clusters along the entire vine. They cook very tender and melting. Seed dark brown. Pkt., 10c; lb., 25c; 10 lbs., \$2.00; 100 lbs., \$17.50.

Kentucky Wonder (WVax)-One of the earliest of the pole wax sorts. Pods eight to nine inches long, thick, decidely crease-back; very fleshy, brittle, but stringy. Attractive and fair quality. Color light yellow. Pkt., 10c; lb., 35c; 10 lbs., \$3.00.

\section{BUSH LIMA BEANS}

Henderson's Dwarf Lima-The earliest variety of dwarf Lima Beans, fully two weeks earlier than any other variety. Plants about 16 inches high and very prolific. Beans are small. Recommended to anyone desiring early lima beans. Pkt., 10c; 1b., 30c; 10 lbs., \$2.50; 100 lbs., \$21.00.

Speckled Bush Lima-This variety is generally known as "calico or speckled" butter bean. The beans are of fine quality, either greenshelled or dry. It is very prolific and does well in the driest weather. The seed is sort of a brownish color. Pkt., 10c; lb., 30c; 10 lbs., \$2.50.

\section{POLE LIMA BEANS}

Carolina or Sieva-Beans small and white on the order of Henderson Bush Lima. Plant of large growth, very early, vigorous and productive. Pkt., 10c; lb., 35c; 10 lbs., \$3.00.

Pole Speckled Lima-This fine Butter Bean is better adapted for the wants of the Southern farmer than any other variety. It is a certain and abundant cropper. The vines are strong growers and cling well to the poles or trellis. Bear early and late. Both pods and beans are larger than the old white Carolina or Sieva Butter Bean. The beans are speckled in color, white splotched with red but are of the very highest quality, both in the green and dry state. Pkt. 10c; 1 lb., 35c; 10 lbs., \$3.00.

\section{GARDEN BEETS}

Culture-As soon as the soil can be worked in spring. sow beet in twelve to eighteen-inch drills for hand hoeing or eighteen to thirtyinch drills for horse cultivation, dropping twelve seed to the foot. Cover the beet seed, which is really a beet fruit containing one or more seeds, one-half inch deep. Later, thin the beets to stand five to the foot. Use one ounce of seed to one hundred feet of row and five or six pounds to the acre.

Crosby's Egyptian-We have an unequalled strain of this superb, extra early sort. A flattened globe shape; skin very dark red, flesh a trifle lighter in color and slightly zoned; tops small. Pkt., 5c; oz., 10c; 1/4lb., 20c; lb., 60c.

Extra Early Ecilpse-A fine early table beet, top-shaped or tapering, globe shaped. Flesh deep crimson, zoned with pink. Crisp and sweet. Pkt., 5c; oz., 10c; 1/4lb., 20c; 1b., 50c.

Detroit Dark Red Turnip-Roots roundish, smooth; dark red; flesh bright red, zoned with lighter; crisp, tender, sweet. a good keeper. Pkt., 5c; oz., 10c; 141b., 20c; 1b., 60c.

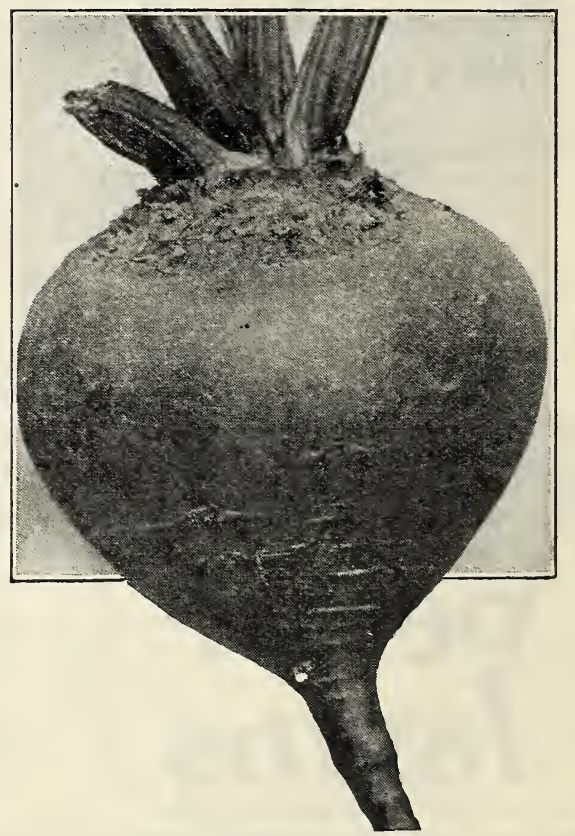

DETROIT DARK RED

Landreth's Best-45 days, five days earlier than Detroit more ball-shaped-altogether a superior sort. Slimmer tap roots-more mouse tailed. Flesh solid, deep blood red of excellent quality, sugary. Skin smooth and free from side fibers. Pkt., 5c; oz., 15c; 14 lb., 30c; 1b., 90c.

Early Blood Turnip-A standard medium early variety of excellent quality; also good for summer and fall use. The flesh is deep red, zoned with lighter shade; sweet, crisp and tender; nearly round. Pkt., 5c; oz., 10c; $1 / 41 b$., 20c; 1b., 60c.

Swiss Chard or Spinach Beet-No other garden vegetable will produce more nutritious food from a small space than Swiss Chard. Of rapid growth. The foliage and leaf-stalks used same as asparagus or spinach. Pkt., 5c; oz., 10c; $1 / 4$ lb., 25c; 1b., 75c. 


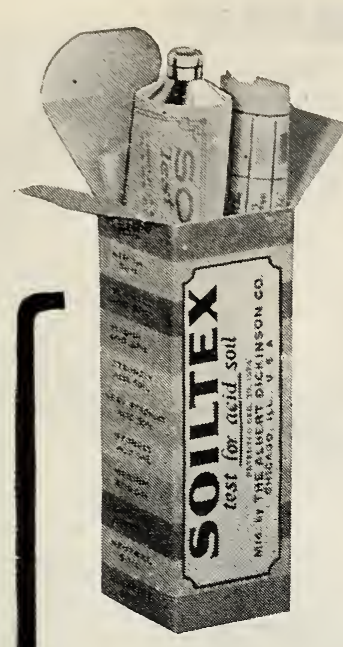

For Lawns, Golf Courses, Vegetable and Flower Gar. dens, SOILTEX provides a simple and economical mearis of testing the acidity of the of testing the acidity of the
soil and determining what soil and determining
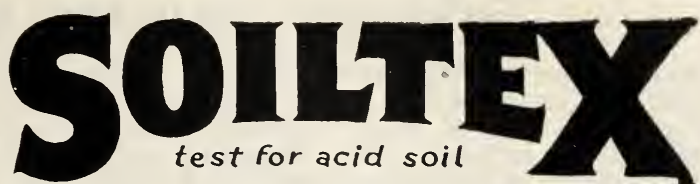

\section{Does Your Soil Need Lime?}

How Much Does It Need? Will it Pay?

"Lime, Legumes and Inoculation"- - this has come to be the slogan of the progressive farmer who wants to grow better crops and increase the fertil. ity of his farm. Alfalfa, Red Clover, Sweet Clover, all require lime. Most other crops are benefited by it. Lime corrects acidity, sets free plant-food, improves the texture of the soil, and is necessary to the activity of nitrogengathering bacteria.

Save Money by Testing Your Soil

To apply less lime than is required, or to fail to apply it when needed, means loss of fertility and poorer crops. To apply more lime than your soil needs is wasting labor and money. Either way, you save money by testing your soil and knowing exactly what treatment it requires.

\section{SOILTEX Tells What Your Soil Teeds}

With Soiltex, a new quick, easy and accurate soil testing method developed at the Michigan State Agricultural College, you can determine ex. actly in a few minutes whether your soil is acid, and how much lime it needs. Each outfit will make 75 to 100 tests. Full directions, color chart and lime table included. No special knowledge or equipment required. Costs less than 2 cents per sample tested. Soiltex will save you money.

\section{SOILTEX}

\section{Choese Your Field!}

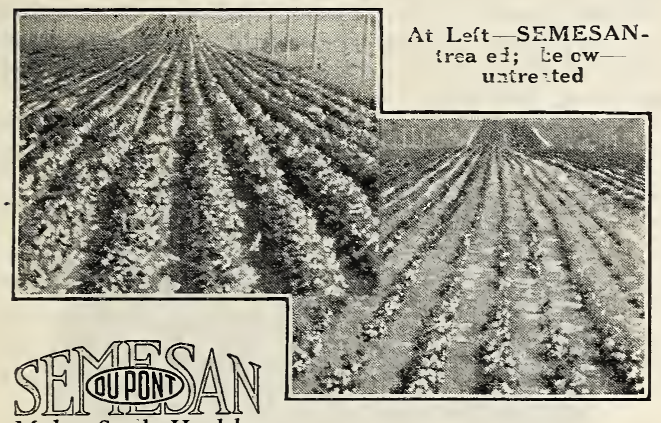

Makes Seeds Healthy

The illustration above shows two sections of the same field, the one on the left was planted with Semesantreated parsley seed. Notice the difference in yield as compared with the untreated section on the right.

Recommended by Government experts, agricultural schools, county agents and large growers in every section of the large growers in every ganic mercury fungicide that can be used in liquid or convenient dust form.

\section{PRICES}

2 oz. $\$ 0 / 50,8$ oz. $\$ 1.60,1 \mathrm{lb}$. $\$ 2.75$. 5 lbs. $\$ 13.00,25$ lbs. $\$ 62.50,50$ lbs. $\$ 122.50,100$ lbs. $\$ 240.09$

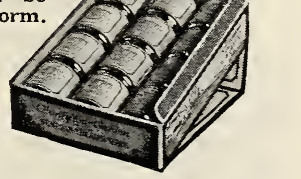

Ask for Semesin Cro? Booklets

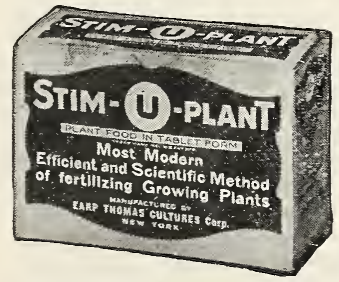

PLANT FOOD IN

TABLET FORM

The modern efficient and scientific method of fertilizing all kinds and condition of growing plants in home garden, orchard and on far'ms.

Stim-U-Plant-Is a 26 grain tablet with a guaranteed chemical analysis of $11 \%$ Nitrogen, $12 \%$ Phosphoric Acid and $15 \%$ Potash. No other plant food contains anything like as high an analysis as this. Stim-U-Plant tablets are composed of water soluble materials of great feeding power and of known weight and percentage of plant food.

Stim-U-Plant tablets should be used directly in the soil. Do not spray on the foliage. No matter how rich the soil may be, these wonderful little tablets will help the plants along.

\section{TABLET FORM OF GREAT VALUE}

1. They give an exact feeding unit

2. No messy mixing.

3. No unpleasant odor.

4. Maximum efficiency because ne foodvalue lost in scattering, leaching, or run-off of soil surface-water.

5. Makes repotting of plants unnecessary as it replaces the food withdrawn by the growing plant.

Stim-U-Plant tablets are packed in three sizes:-

Trial Size, 15 cents. Containing 10 Tablets. Small Size, 25 cents. Containing 30 Tablets. Medium Size, 75 cts. Containing 100 Tablets. 


\section{MANGEL WURZEL BEETS}

Giant Feeding Sugar Or Half Sugar Mangel - A beet which is superior to Mangels for stock feeding purposes, as it is more nutritious, having a large amount of sugar. It is oval in shape and grows partly out of the ground. It is of large size and yields enormous crops. Pkt., 5c; oz., 10c; 1/4 lb., 15c; lb., 40c.
Improved Mammoth Long Red-The largest of all the Mangels and the heaviest cropper. Skin is red, flesh white zoned with red. This variety produces a larger amount of good feed than any other beet, and is recommended as superior to all others. Pkt., 5c; oz., 10c; $1 / 4$ lb., 15c; 1b., 40c.

\section{CABBAGE SEED}

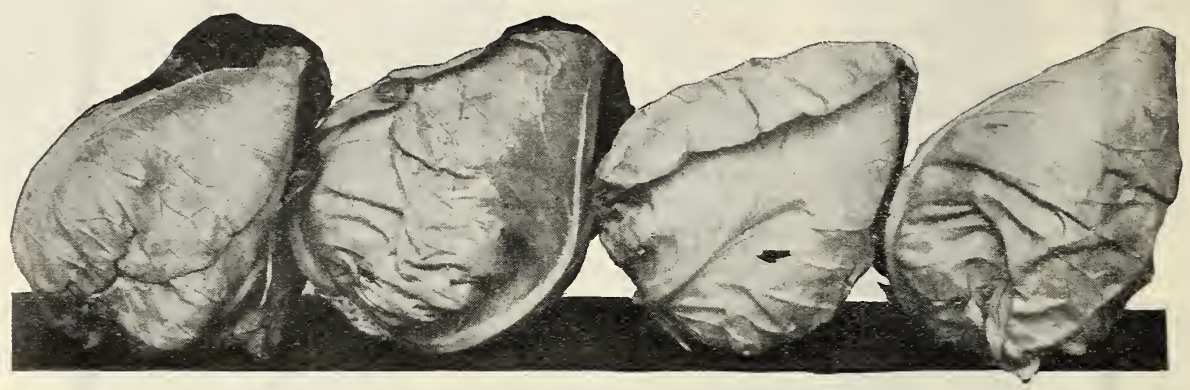

EARLY JERSEY WAKEFIELD

Culture-Cabbage grows successfully on a wide variety of soils and experience points to liming, deep plowing and heavy manuring means success to cabbage raising. One can set cabbage plants out as early as February or March, which have been wintered over either in cold frames or out of doors. This setting will give you the earliest cabbage. For a succession sow the seed of the early varieties in hot-beds or cold frames either in January or February. Later sow the early varieties out doors. For winter or fall cabbage sow your seed in May or June, and in July or August transplant in the field. For setting out plants in the fall for making early cabbage in the spring the seed should not be sown before the $22 \mathrm{nd}$ of September, for if they are sown earlier you are more likely to have most of them shoot to seed instead of making heads. Early varieties should be set about 18 inches apart in three-foot rows. One ounce will produce 1,500 plants, eight ounces will make plants for one acre. We will always have plants in season; see plant list price page.

Early Jersey Wakefield-The most widely known and popular extra early variety. Heads are broad cone shaped and very solid. Pkt., 5c; oz., 25c; 1/4 Ib., 50c; 1b., \$1.50.

Charleston Wakefield-About one week later than Early Jersey Wakefield, but the conical heads are fully one-half larger. Pkt., 5c; oz., 25c; 1/4 lb., 50c; lb., \$1.50.

Stein's Early Flat Dutch-An early and excellent type of Early Flat Dutch, with a medium stem; heads round, flat and solid. Pkt., 5c; oz., 25c; 1/4 lb., 50c; lb., \$1.50.

Copenhagen Market-Very fine; stem short, heads large, round and solid, with few outer leaves of an upright growth. Nearly as early as Jersey Wakefield. Pkt., 5c; oz., 40c; 1/4 1b., \$1.00; lb., \$3.00.

Early Drumbead-We recommend this sort for markets that require a very large and deep head. Plant large, with fow outside leaves, stem of medium length. A sure neading var- iety of excellent quality. Pkt., 5c; oz., 20; 14 1b., 50c; 1b., \$1.50.

Danish Ball Head-One of the very best winter sorts and one of the most hardy; heads round and very solid. Our selected stock of this cabbage is unexcelled. Pkt., 5c; oz., 25c; 1/4 lb., 50c; lb., \$1.50.

Volga, or Russian-A new medium sized sort, with round, solid heads, which are deep through. It is extremely hardy. Pkt., 5c; oz., 35c; 1/4. lb., \$1.00; lb., \$3.00.

Red Rock-The largest and surest heading red cabbage, round, solid and dark red, medium to long stem. Pkt., 5c; oz., 25c; 1/4 lb., 60c; ib., \$1.75.

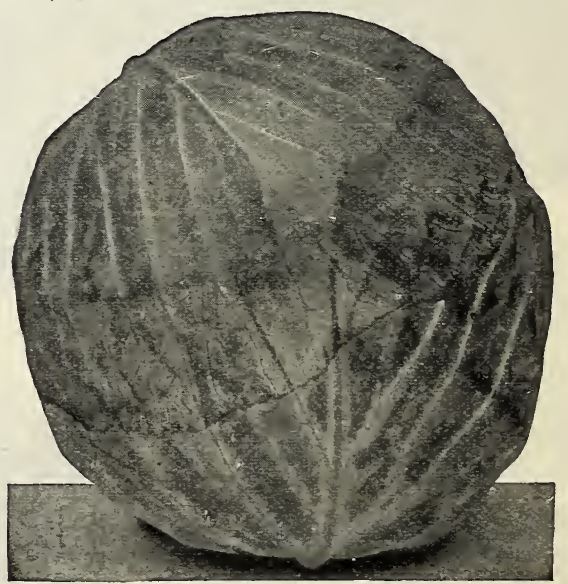

CUPENHAGEN MARKET

Drumhead Savoy-Heads round, compact and solid; leaves numerous, deep green and coarsely crimped. Pkt., 5c; oz., 25c; 1/4 lb., 60c; lb., $\$ 1.75$.

Chinese Cabbage ( $\mathrm{Pe}$ Tsai-Sometimes called Celery Cabbage; resembles Cos Lettuce as much as cabbage, though with a decided cabbage flavor. Pkt., 5c; oz., 50c; 14 lb., \$1.50; lb., \$3.50. 


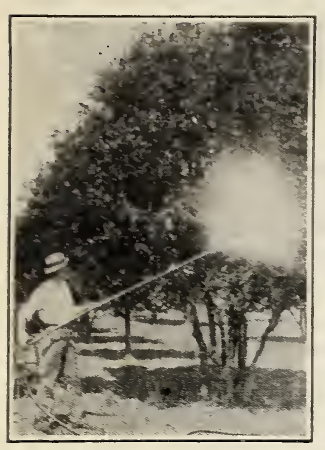

Comply with all Federal

\section{INSECTICIDES and FUNGICIDES}

Take the speculation out of spraying

\section{ACME SPRAYING GUIDE}

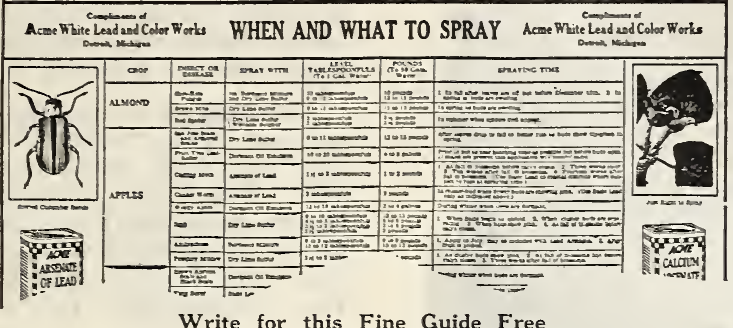

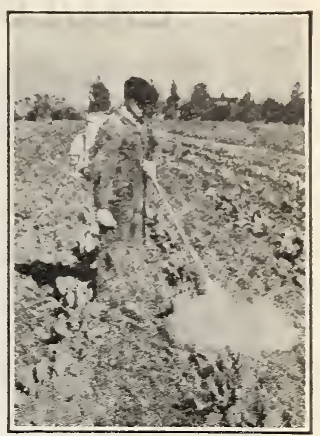

Prices Subject to Change Write for Quantity Prices
Acme Garden Guard

A garden insecticide and fungicide for use as a dust. No water, no mixing, no muss.

\section{For use on}

Cabbage, cauliflower, tomato plants. melon vines, currants and gooseberries and other regetables, flowers and shrubs of many kinds.

Prices: 1 lb. sifter carton, 25c; 5 lb., 75c.

\section{Acme Paris Green}
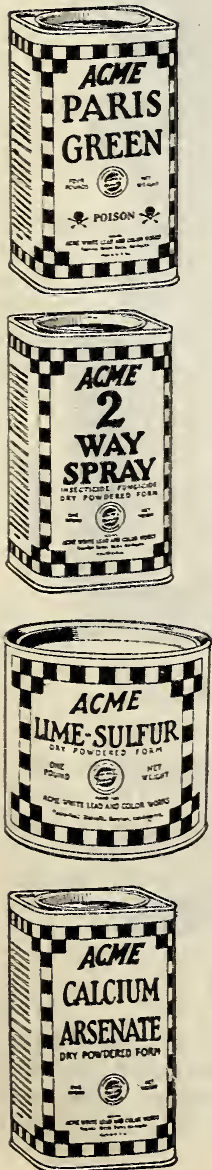

A rich. emerald color and of fine fluty physical character. Containing quickest control where extreme measures are necessary.

For use on:

Potatoes, cotton, tobacco, also to mix with arsenate of lead for fruit tree spraying where quick results are necessary.

Prices: 1/4 lb., 15c; 1 lb.. 50c; 5 lb. $\$ 2.25 ; 14$ lbs., $\$ 5.00$.

\section{Acme Two-Way Spray}

A balanced insecticide and fungicide containing $14 \%$ arsenate of lead and $83 \%$ Bordeaux Mixture. Two results with one application.

Use wet or dry on:

Apple, sour cherry, currant and gooseberry, grape, pear, plum. strawberry, pecan, bean, beet, cucumber, pepper, potato, tomato and many other fruits and regetables.

Prices: $1 / 2$ lb., 25c; 1 lb., 40c; 4 lb., $\$ 1.40$.

\section{Acme Lime Sulfur}

A standard $33^{\circ}$ Baume lime and sulphur converted into a dry powder but having all the effectiveness of the liquid product when dissolved in water. For use on:

Dormant spraying against scale, peach blight, leaf curl and twig borer. Summer spraying against scab, soot, blotch, red spider and mite. Prices: 1 lb., 30c; 5 lb., \$1.25; $10 \mathrm{lb}$. $\$ 2.25 ; 25$ lb., $\$ 4.75$.

\section{Acme Calcium Arsenate}

The cheapest arsenical insecticide on the market but of great economy and efficiency for certain purposes. The accepted dust for boll weevil poisoning on cotton; also recommended to com. bat chewing insects on potatoes, vegetables, cotton and certain fruit trees.

Prices: 1 lb., 20c; 4 lbs., 60c; 100 lbs., $\$ 8.00$. lb., 35c. deaux Mixture. lb., 15c; 100 lbs., \$12.00. lb., 10c; 100 lbs., $\$ 7.50$. or mildew on roses, lb., 10c; 100 lbs., $\$ 5.00$.
Acme London Purple

A farored insecticide for 50 years. Now stronger, and better than ever. London Purple is one of the lightest and fluffiest powdered insecticides on age and greatest adhesion to foliage.

For use on potatoes, cotton, tobacco, sugar beets and many other shrubs and vegetables affected by leaf cliew ing insects.

Prices: $1 / 4$ lb.. 15c; 1 lb., 50c; 4 lb. $\$ 1.80$.

\section{Acme Arsenate of Lead}
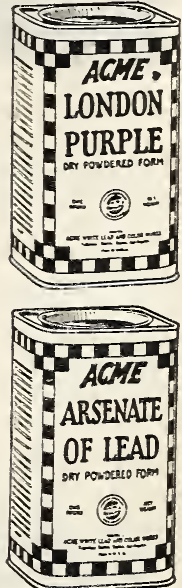

The most favored arsenical insecticide found on the American market. It is safest to use on tender foliage and sticks well on the leaves. Recommended for fruit trees. vegetables, bushes and tobacco. Can be used as dust or spray. Prices:
4 lbs., $\$ 1.20$.

\section{Acme Bordeaux Mixture}

Prevents large losses by blight, rot mildew. scab, anthracnose and certain other fungous diseases. It stimulates plant growth and greatly increases the harrests. Almost erery kind of regetable, iruit and shrub can be greatly improved by the early use of Borlb., $\$ 1.00$.

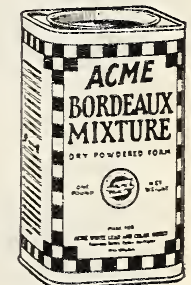

Slug Shot, Hammond's---Guaranteed to destroy potato bugs and those in tomato and egg plants, currant worms, cabbage lice and worms. 1 lb., 15c; 5 lbs., 60c.

Fish Oil Soap-Very effective in destroying many suck ing insects and lice on plants, trees and shrubbery.

Copper Sulphate (Blue Stone)-Used for making Bor-

Copperas (Sulphate of Iron)-A splendid neutralizer of alkali in the soil Use one to two pounds per tree, also fine for lawns. lb., 6c; 25 lbs., \$1.25; 100 lbs., \$4.50.

Tobacco Dust-Effective against Cabbage fly and worms.

Dry Milled Sulphur--Used as a fungicide, also for blight

Black L.eaf " 40 "- A concentrated solution of nicotine sulphate for combating aphis or plant lice. 1 oz. bottle $35 \mathrm{c}$; $1 / 2$ lb. can $\$ 1.25 ; 2$ lb. can $\$ 3.50 ; 10 \mathrm{lb}$. can $\$ 13.50$ 


\section{CAULIFLOWER}

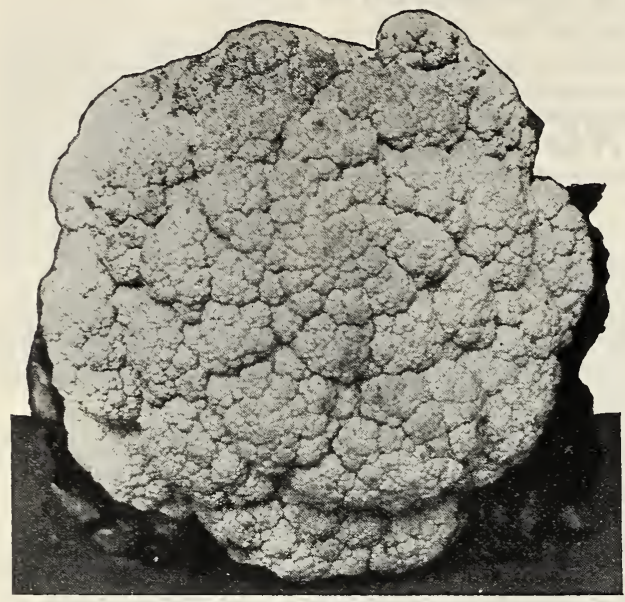

EARLY SNOWBALL

Culture-The culture for cauliflower is practically the same as for cabbage, and it can be grown both in the spring and fall. For early crop sow seed in hotbed in January or February. Seed for the late crop should be sown in May or June, transplanting same as late cabbage. When the heads are about 2 inches across, gather up the outer leaves and tie. This will protect and blanch the heads making them of much better quality.

Early Snowball-We believe this to be the best variety in existence. It is early, of dwarf compact growth and sure to produce fine heads. Very much depends on the quality of Cauliflower seed. We handle only the best. Danish-grown seed from a well known, reputable grower, which we confidently recommend. Pkt., 25c; oz., \$2.00; 1/4lb., \$5.00; lb., \$15.00.

\section{CARROTS}

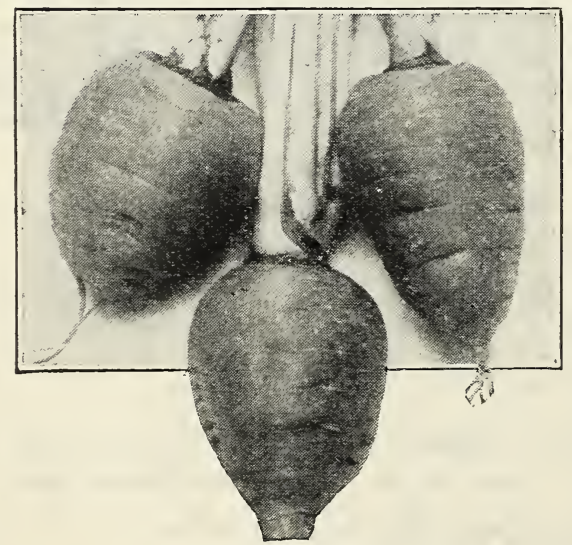

OXHEART

Culture-One ounce is sufficient for one hundred feet of drill; two to four pounds to the acre. Carrots ought to be sown in light fertile soil. which has been heavily manured the previous year. Sow in drill one-half inch deep; rows from 18 inches to two feet apart. thin out to two to three inches apart. Sow as early as the ground can be worked for the early crop; for late crop, sow in July.

Orange Danvers Half Long-Broad shouldered, cylindrical, admirable in color. Always a favorite because reliable and attractive in form, color and weight. Most popular sort. Pkt., 5c; oz., 15c; 1/4 lb., 30c; 1b., 90c.

Oxheart or Guerande-One of the most popular and best croppers among the short carrots. The shape is particularly desirable for heavy soil. The true type is about four and one-half inches long and three and one-half inches thick at the shoulder. It tapers slightly to the bottom, and is very stump rooted. Pkt., 5c; oz., 15c; 1/4 lb., 30c; 1b., 90c.

Chantenay-One of the best carrots for all purposes. Roots about 6 inches long, blunt pointed, smooth, fine grained and sweet, a heavy yielder. Pkt., 5c; oz., 15c; 1/4 lb., 30c; lb., 90c.

\section{CELERY}

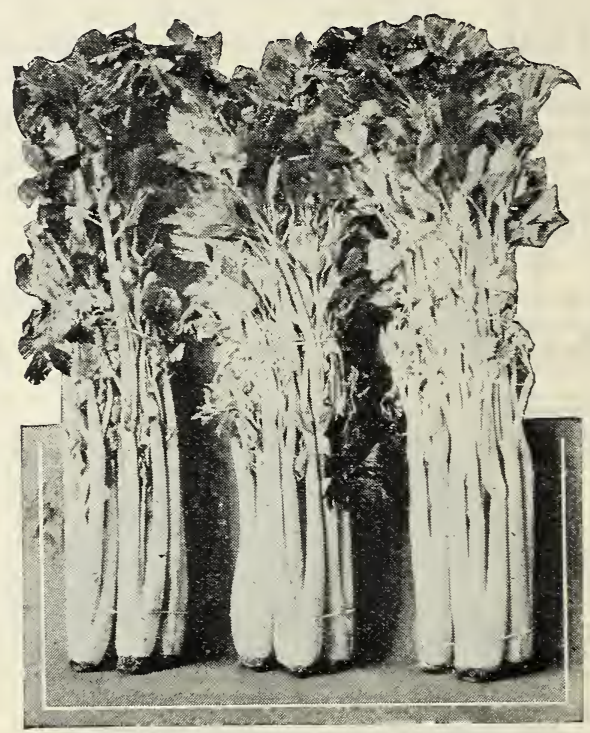

\section{GOLDEN SELF BLANCHNG}

Golden Self-Blanching-The best market variety, especially for early summer. The plant is naturally golden-yellow (both stem and leaves, but needs to be blanched to make it brittle and fit for table use. Forms a rather small bunch. Pkt., 10c; oz., 75c; 1/4 lb., \$2.00.

\section{COLLARDS}

Georgia Southern-Plant 2 to 3 feet high, forming a cluster of tender undulated leaves at the top of its rather long stem; used as greens. Pkt., 5c; oz., 15c; $1 / 4$ lb., 35c; lb., $\$ 1.00$. 


\section{SPRAY PUMPS}

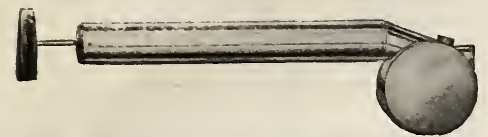

We carry in stock two styles of Hand Sprayers, No. 2 and No. 4. They are made of good grade material, and will give good service.

Pt. No. 2 Hand Sprayer (not postpaid) 35c.

Qt. No. 1 Hand Sprayer (not postpaid) 50c.

\section{It Sprays Continuously}

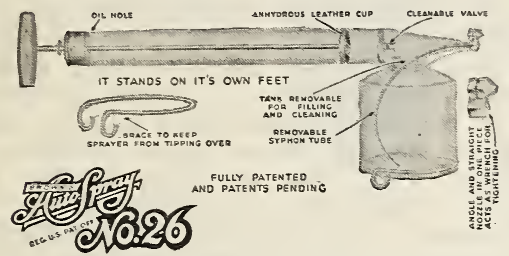

The Continuous Sprayer has a feature which will give you a continuous spray as long as there is any air left in the tank, and for this reason is used a great deal, as it is not fatiguing to operate same.

Continuous Sprayer (not postpaid) \$1.25.

\section{LOWELL POWDER GUN}

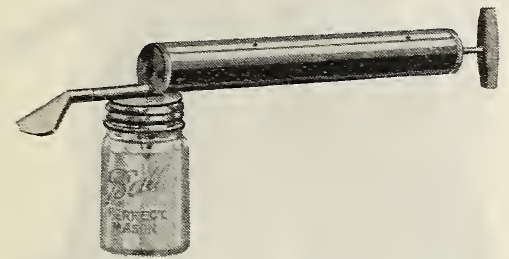

Lowell Powder Gun.-This sprayer is easy of operation. Fill reservoir with dry powder, such as Hammonds Slug Shot, Bug Death, Paris Green, Hellebore, Powdered Arsenate of Lead, etc. Size of spray regulated by operation of plunger. Elbow reversible. enabling operator to spray up or down \$1.00.

\section{HUDSON CADET DUSTER}

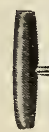

\section{HUDSON}

TADT

A strong constructed, very efficient duster for the home gardener. Dusts any kind of powder. Weight 1 lb., each 50c.

\section{DUSTER BROWN NO. 2}

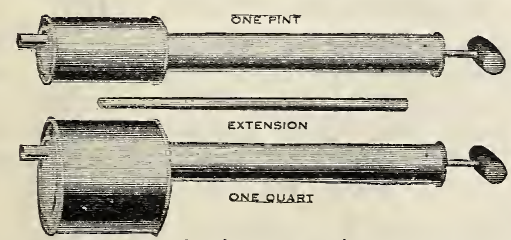

A very practical, inexpensive duster of new design. It is of simple construction, single acting. USES-For spraying dust on small garden plots, rose bushes or in any place where dust is to be applied in small quantities. It is especially adaptable for use in applying insect powders. Shipping weight 2 lbs.

\section{THE G-V CONTINUOUS SPRAYER}

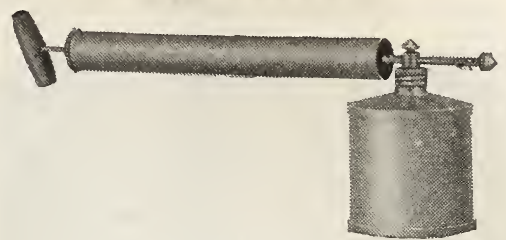

The G-V Continuous Variable All-in-One Sprayer is the only sprayer on the market that can be used as a fire maker, pipe thawer, flame sterilizer and oil generator besides being a perfect sprayer for insecticides, disinfectants, lubricating oil, paints and lacquers.

G-V No. 1, Tin-Shippng Weight 2 Jbs. … $\$ 1.50$ G-V No. 2, Brass-Shipping lleight 2 Lbs. 2.50

\section{VERMOREL ORANGE DUSTER}

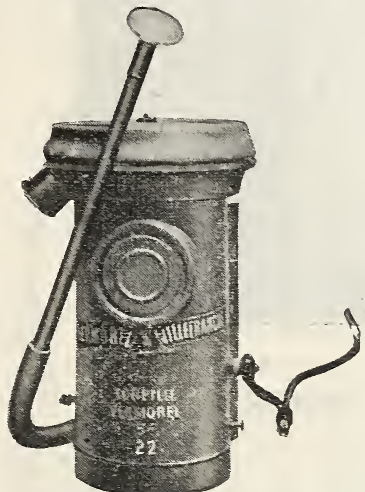

Annoyance and loss of time due to choking is entirely eliminated through correct agitation insured by the brush agitator

Single Action; Bellows Type.

. Very light and compact in construction. Weight eleven pounds; capacity six quartsnine to fifteen pounds of material.

Price

$\$ 15.00$

\section{HUDSON PERFECTION SPRAYER}

Has a tank made like a steam boiler. The allriveted seams give the necessary strength for developing a high presdeveloping a high pressure, which is absolutely
essential for good results. essential for good results. The all-brass pump is
placed inside the tank and is easily removed. For work of any kind requiring a high pressure compressed a ir sprayer the Perfection is supreme. It can be used around the house and ard, the house and yard, the barnyards and outhouses, on truck farms, in vineyards, pot a to. and in all sizes of or and in
chards.

chards.

No. $140 \mathrm{G}$ Galvanized Tank, $1 \mathrm{I} / 2$ Gal........ $\$ 4.50$ No. $110 \mathrm{G}$ Galvanized Tank, 31/2 Gal........ \$6.5 No. 110B Brass Tank, $31 / 2$ Gal.
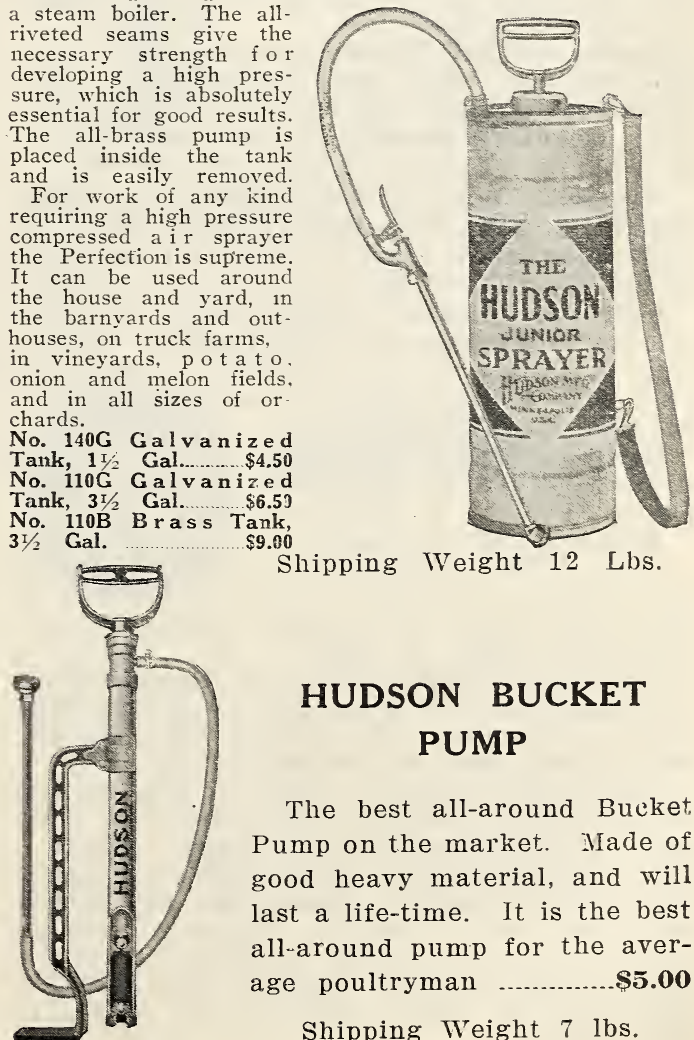

Shipping IVeight 12 Lbs.

\section{HUDSON BUCKET PUMP}

The best all-around Bucket Pump on the market. Made of good heavy material, and will last a life-time. It is the best all-around pump for the average poultryman

$\$ 5.00$

Shipping Weight 7 lbs. 


\section{SWEET CORN}

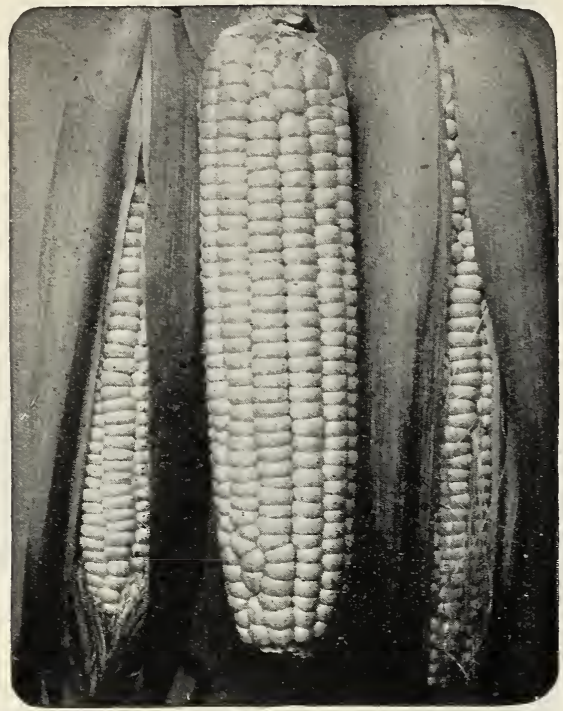

GOLDEN BANTAM CUCUMBER

Culture-For the general crop plant in the open -ground as soon as the weather becomes settled warm, about the 1 st of April, not over an inch deep, in hills about ten feet apart each way. The hills should be previously prepared by mixing well-rotted manue with the soil. Put parout ten seeds in each hill, and when all danger of frost is past thin out to four plants, and give frequent frost is past thin out
but shallow cultivation.

Improved Early White Spine-Vines vigorous, fruiting early and abundantly. Fruit good-sized, straight and smooth. Splendid for table use and especially desirable for pickles. Pkt., 5̌c; oz., 15c; 1/4 lb., 35c; lb., \$1.00.

Improved Long Green-Uniform in size, straight, smooth, and deep green in color. A great favorite for slicing. Pkt., 5̃c; oz., 15c; 1/4 1b., 35c; lb., \$1.00.

Improved Chicago Pickling-Meets the most exacting requirements of critical pickle makers. Vines healthy and very productive. Fruit the right size, shape color and quality. Pkt., 5c; oz., 10c; 14 1b., 30c; lb., 85c.

Early Fortune-Early, good dark color and prolific. Fruits average about 10 inches...Pkt., 5c; oz., 15c; 1/4 1b., 35c; lb., \$1.00.

Arlington White Spine-One of the most popular White Spine sorts. The fruits are very uniform, averaging 7 to 8 inches. It is extra early and very prolific. Pkt., 5c; oz., 10c; $1 / 4$ lb., 30c; lb., 90c.

Extra-Long White Spine, or Evergreen-A fine strain; smooth, frequently 10 inches long; round, handsome, very regular. Pkt., 5c; oz., 20c; 1/4 lb., 50c ;1b., \$1.25.

Kirby Stay Green-"Kirby" is the earliest of the White Spine type; fruit seven to e:ght inches long, cylindrical in shape. Coor a beautiful dark green from stem to blossom end, which is retained longer than any variety we know of. Vigcrous grower, enormous yielder, shipping quality unexcelled, and always commands the highest market price. Pkt., 10c; oz., 15c; 1/4 1b., 45c; 1b., \$1.25; 10 lbs., \$11.50.
Culture-Plant from March to July, one inch deep in row, three feet apart, leaving eighteen inches between the plants. The small extra early varieties may be planted as close as two feet, providing the soil is very rich, or the ground has been heavily fertilized. As sugar corns are very sensitive to cold and damp weather, they should not be planted until the ground has become thoroughly warm.

Golden Bantam-Early; golden yellow in color and of highest quality. Ears 6 to 7 inches long, 8 rowed, bearing from 2 to 4 ears to a stalk. Pkt., 10c; lb., 25c; 10 lbs., \$2.25.

Extra Early Adams-This is not a Sugar Corn, but is earlier. The ears are short, 12rowed, and while in condition for roasting cannot be told from Sugar Corn. It will stand earlier planting than Sweet Corn and is a favorite wherever worms work badly on early corn. Pkt., 10c; lb., 20c; 10 lbs., \$1.75.

Country Gentleman-An especially fine quality corn, cob small, white and densely covered with long slender white grains without row formation. Pkt., 10c; 1b., 25c; 10 lbs., \$2.25. -Truckers Favorite-A splendid early white Corn coming in directly after Adams Early, but much larger. Has a deep white soft grain. Pkt., 10c; lb., 20c; 10 lbs., \$1.75.

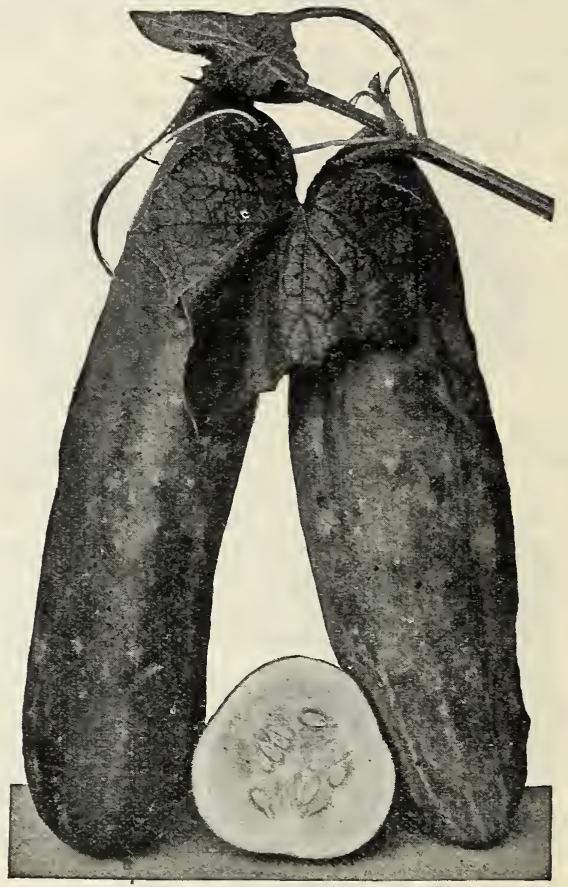

EVERGREEN WHITE SPINE

Burrell's Earliest of All-Earlier than any other strain of white spine and as well colored as any cucumber grown. The fruit is 6 to 7 inches long, very dark green with pale green stripes about one-third the length from the blossom end. Pkt., 5c; oz., 15c; 1/4 1b., 30c; lb., 90c.

Clark's Special-This special strain developed a period of years for critical market garden trade has outstanding merits as a main crop Cucumber. First, it is a good shipper and will hold its color and firmness when handled over long distances. Second, it has a very attractive deep over long distances. Second, it has a cicumber that we green color, being the darkest green cucumber that wh running from 8 to 10 inches, and smooth in appearance running from 8 to 10 inches, and smooth in appearance seed pcckets it is of excellent quality for slicing. Pkt., 5c; oz., 15c; $1 / 4$ lb., 30c; lb., $\$ 1.00$. 


\section{BROWN AUTO SPRAY}

Has a tank made of h eavy non-corrosive sheet brass or galvanized steel, air $\mathrm{pump}$ and syphon tube of seamless' brass tubing; pump handle of sturdy malleable iron. $\mathrm{T}$ h $\mathrm{e}$ air pump located inside solution tank is made absolutely airtight by a locking device of collar and locking $\mathrm{nut}$ of brass. Capacity of tank $3 \frac{1}{2}$ gallons. $\mathrm{Sh}$ i p pi $\mathrm{ng}$ weight $12 \mathrm{lbs}$.

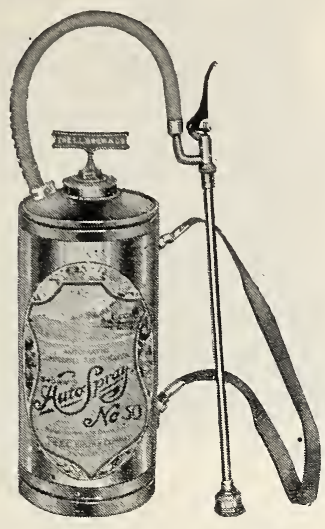

No. 9B-Brass tank

$\$ 9.00$

No. 9D-Galvanized tank

6.50

No. 50D-Galvanized, 2 gal Shipping Weight 7 lbs.

4.50

LOWELL COMPRESSED SPRAYER

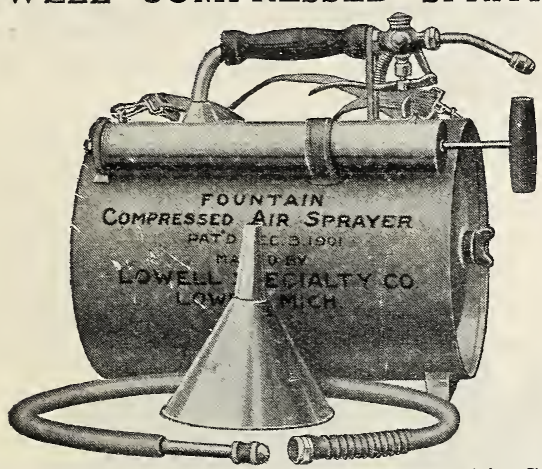

The Lowell Fountain Compressed Air Sprayer is well adapted for the fruit grove, farmer, stockman, poultryman, florist, and for use of general disinfectants. It is the strongest small tank sprayer ever made, being constructed of heavy sheet brass or galvanized steel.

No. 111 Brass, 3 gallon.

8.75

No. 110 Galvanized, 3 gallon

6.50

Shipping Weight $12 \mathrm{lbs}$.

LOWELL BABY FOUNTAIN COMPRESSED AIR SPRAYER

Capacity of tank, one gallon

No. 120

\section{BROWN BUCKET PUMP}

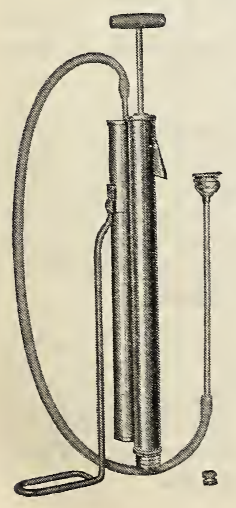

A medium priced $\mathrm{b} \mathrm{u} \mathrm{c} \mathrm{ket}$ pump, capable of doing all the spraying for the average poultryman and farmer. Made of good material and with proper care will give long service. \$2.75 not postpaid

\section{ANGEE FOG NOZZLE}

This nozzle is especially reco m m ended for spraying the underside of the leaves of $\mathrm{vine}$ crops. Ea....75c

\section{HUDSON BARREL SPRAY PUMP}

In our No. 4, we have developed a pump that will meet every requirement of a perpendicular $\mathrm{B}$ a $\mathrm{r} \mathrm{r}$ e 1 Pump. It is powerful, light and durable and will develop better than 250 pounds pressure with ease. Can be used with either one or two lines of hose.

No. 4A--Outfit consists of No. 4 Pump, 121/, feet $1 / 2$ inch Sprayer Hose and Fog Nozzle .................\$14.00

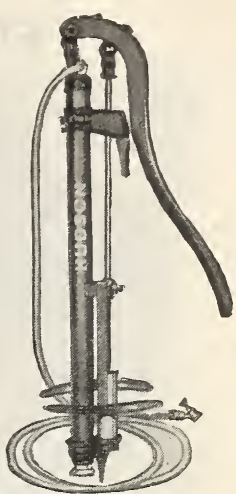

BROWN BARREL SPRAY PUMP

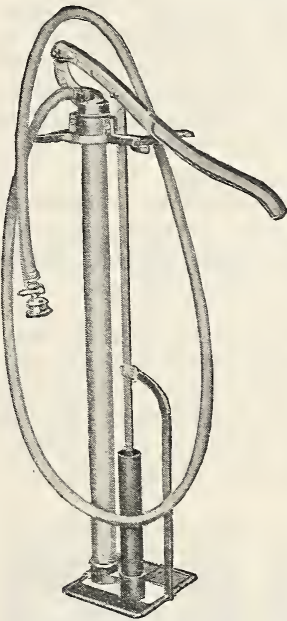

BROWN'S AUTO-SPRAY No. 4-Because of its special design this pump is light in weight and consequently it is com. paratively inexpen sive. However, it is durable and sturdy in construction. Auto-Spray No. 4 accommodates one lead of hose although it can be used with an attachment for using two nozzles in a cluster. The long air chamber stores up reserve pressure so that nozzle $\mathrm{th} \mathrm{row} \mathrm{s}$ a long continuous s p ray. Agitator is automatic in operation and functions as long as the pump is being operated.

Pump cylinder $1 \frac{1}{2}$ " in diameter. Valves at bottom of pump are of brass and are in a brass casting. Plunger head brass. Casting on top of pump and air chamber of iron. Packing is a graphite composition. Shipping weight 25 lbs. Price \$12.00.

\section{INSECT POWDERS}
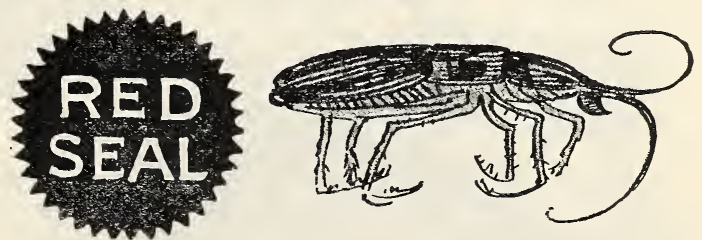

Red Seal Insect Powder-Odorless and nonpoisonous. A guaranteed exterminator of roaches, flies, water bug ${ }_{3}$ and fleas. 4 oz. can, 50c; $10 \mathrm{oz}$. can $\$ 1.00$.

Pyrethrum Flowers Ground-A powder for use against mosquitos, roaches, moths, flies, ants and many other insect pests. 1b., 60c.

Sodium Fluoxide-Highly recommended for dusting or dipping poultry to destroy lice, also a splendid preparation to rid premises of roaches. 35c $1 \mathrm{~b}$.

Martin's Liquid Bug Spray-A stainless insecticide with a pleasant odor used for bed bugs, roaches, mosquitos, etc. Pints 40c; qts., 75c. 


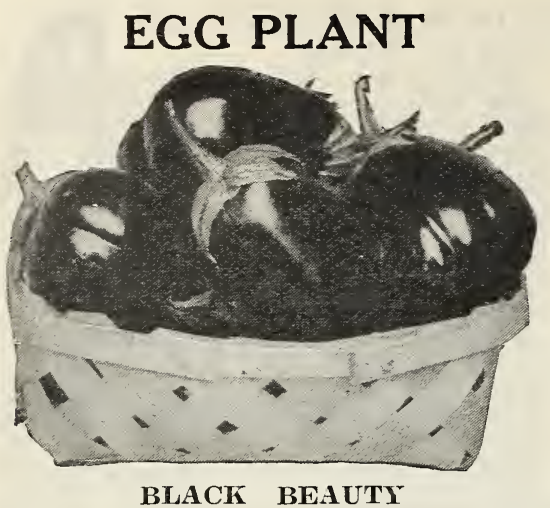

Culture-Six ounces will usually produce enough plants to $s \leq t$ an acre. Sow seed in a special prepared hotbed, as they require more heat than it is necessary or desirable for other plants. Sow one quarter of an inch deep in February or early March and keep the sash on until the plants appear, after which air must be given on warm days; close attention being given them during the earlier stages. When two or three inches high, prick them out into small pots to induce stockiness.

Black Beauty-Rich dark purple, large and symmetrical, maturing a little earlier than our Improved Large Purple, but usually not quite as large. Very desirable for the market, as the fruit holds its color for a long time...Pkt., 5c; oz., 50c; 1/4 lb., \$1.25; lb., \$4.00.

Improved Large Purple (Spineless)-This variety is a general favorite both for market and home garden. The plant is spineless, large and spreading, with light green foliage. It usually produces four to six large, oval fruits of a splendid dark purple color. The vigor and productiveness and fine quality of the fruit makes it a most profitable variety for market gardening. Pkt., 5c; oz., 50c; 1/4 lb., \$1.25; 1b., \$4.00.

\section{ENDIVE}

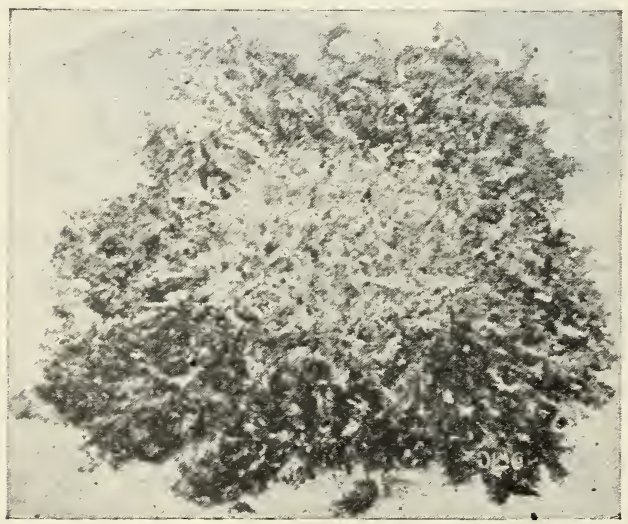

GREEN CURLED SUMMER ENDIVE

Culture-Same as Lettuce. Seed may be sown anytime during the year. When plants are well started, thin out to ten inches apart or they may be transplanted. $1 \mathrm{oz}$. will sow 100 foot row.

Iarge Green Curled-Has very curly leaves, the mid-ribs being white and whitish, and the outer edges very much indented and crested. A very attractive plant and one of the best varieties. Pkt., 5c; oz., 15c; $1 / 4$ lb., 35c; Ib. $\$ \mathbf{\$ 1 . 0 0 .}$

Ever White Curled-The plants are moderately dense, with divided leaves, which are very light yellowish-green in color, even the outer ones being very light. This variety blanches readily to an attractive creamy white. Pkt., 5c; oz., 15c; 1/4 lb., 35c; lb., \$1.00.

\section{KALE}

Dwarf Curled Scotch-A finely c u r led, spreading, low growing variety, very hardy and much used for greens. This sort sometimes called Norfolk, is grown extensively in the South for shipment, and is largely planted for the home garden. The leaves are long, and attractive bright green. This sort is often used for garnishing. Pkt., 5c; oz., 10c; 1/4 lb., 30c; lb., 90c.

\section{KOHL RABI}

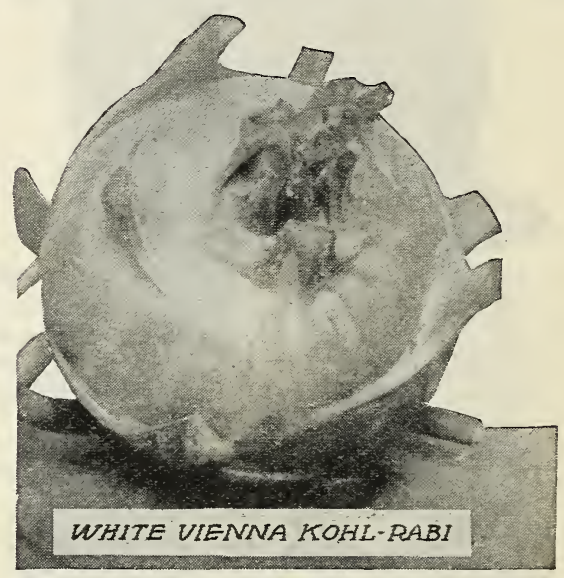

EARLY WHITE VIENNA

Culture-Sow in drills as soon as ground can be worked in spring and up to fall. When well started set out in rows about 8 inches apart. $1 \mathrm{oz}$. will sow 200 foot row.

Early White Vienna-A turnip-like bulb, formed above ground, combining somewhat the flavor of cabbage and turnips. The bulb is large enough to be used in 10 to 12 weeks from time to sowing, and is most tender and deliciously flavored before fully matured. Pkt., 5c; oz., 20c; 1/4 lb., 60c; lb., \$2.00.

Large Green-This sort is also called Large White. It is hardy, quite late, and used for feeding stock. Bulbs large, weighing 8 to 10 pounds when fully grown; whitish green in color, leaves large and very numerous. Pkt., 5c; oz., 20c; $1 / 4$ lb., 60c; Ib., \$1.75. 


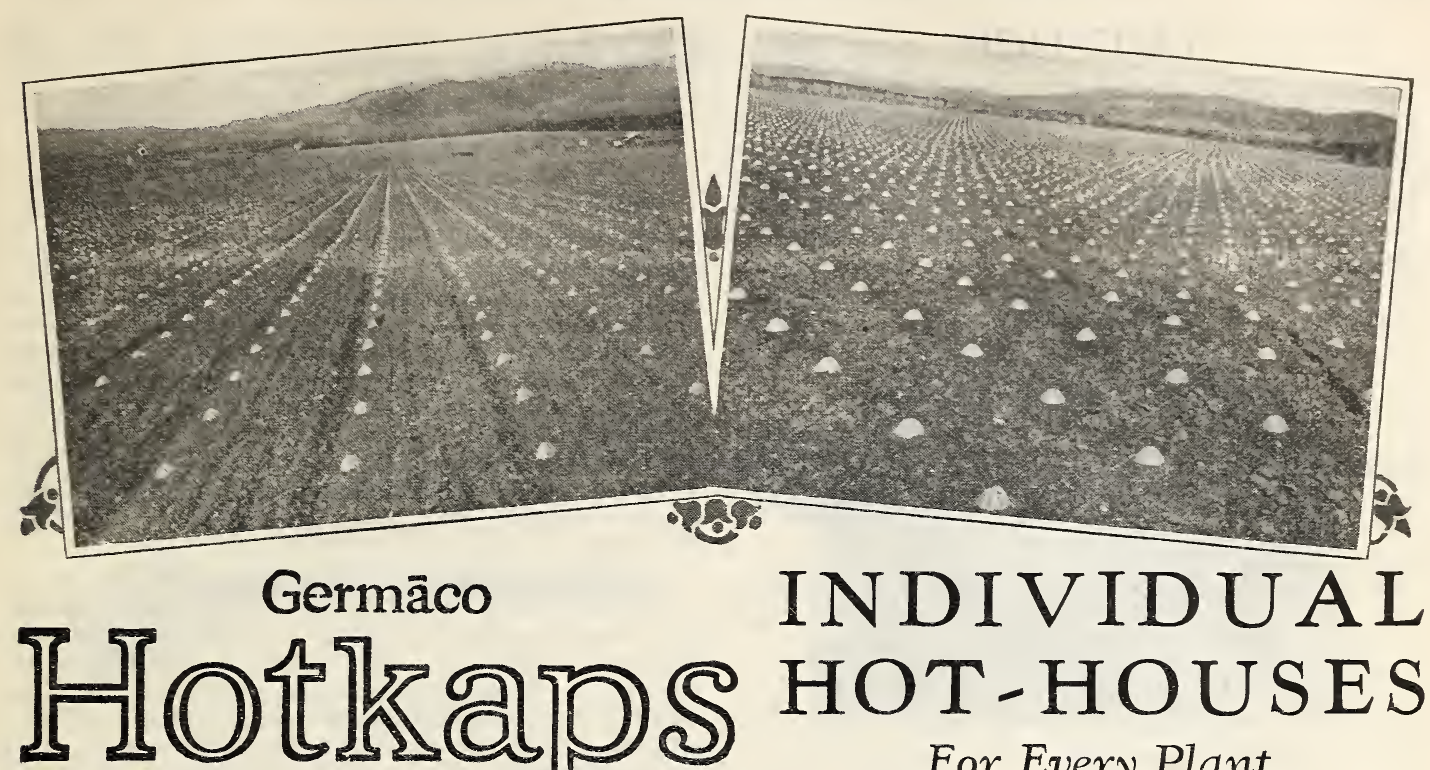

For Every Plant

"Hotkaps" Furnish Each Young Plant With Complete Protection From Wind,

Rain, Frcst and Insects. Now Have Hardier Crops That MATURE EARLIER.

Ask us about the interesting new invention, "Hotkaps."

They are individual hothouses for each plant, economically priced, to insure against the crop hazards of frost, rain, wind and insects. They are made of strong, durable, especially prepared waxed paper, light in weight, easy to use, easily rentilated.

"Hotkaps" bring crops to earlier maturity. Many write us that they have been first to market by from one to three weeks, and as a result have been able to get higher prices.

Farmers quickly appreciate them. Once you've tried them, you'll always use them. They afford the best crop insurance, and bring you more profit.

"Hotkaps" are packed 1,000 to the roll.

Prices: $1,000, \$ 10.00 ; 5,000$ at $\$ 9.75$ per 1,$000 ; 10,000$ at $\$ 9.50$ per 1,000. “Hotkap" Setters, each $\$ 2.50$; “Hotkap'

Carriers, each $\$ 2.75$. Postage extra.
Prices on smaller quantities-100, $\$ 1.50$, postpaid.

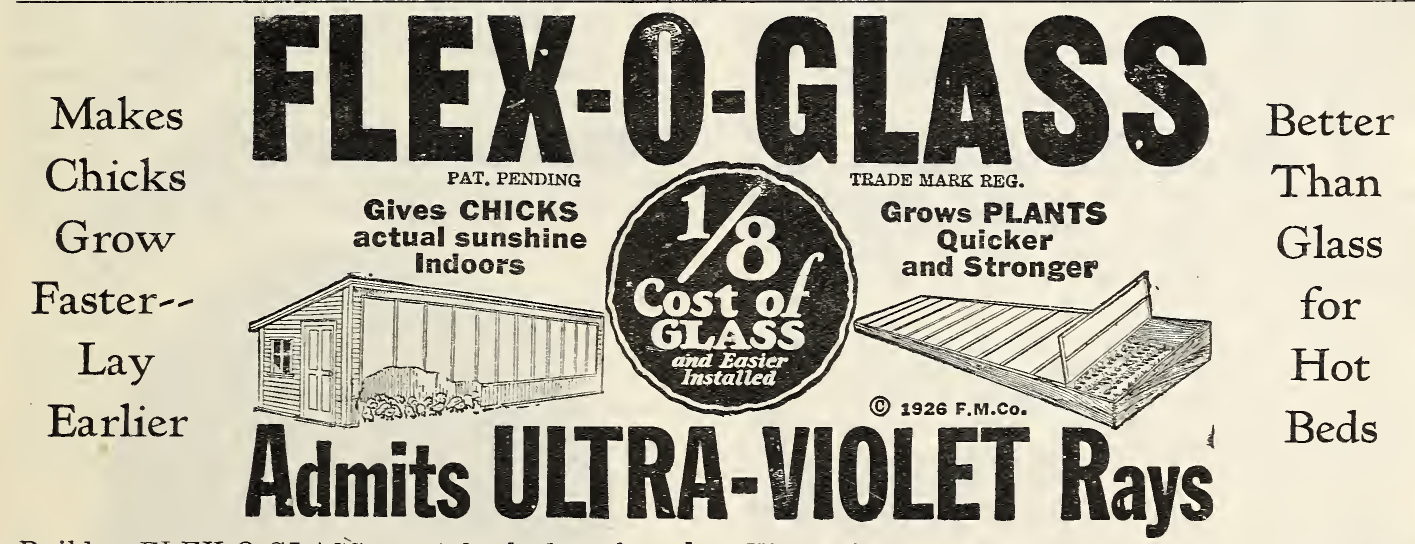

Build a FLEX-O-GLASS scratch shed or brooderhouse front easily. In it every chick will stay healthy, scratch and exercise, be full of pep, free from rickets, and they will grow like weeds, because FLEX-O-GLASS admits energizing, health producing Ultra-Violet sun's rays (glass stops them). Science has proved that FLEX-O-GLASS also brings amazing winter egg yield and fertile hatching eggs. Use 15 yards for 300 chicks, or for 100 hens. For replacing or repairing glass windows, enclosing porches and storm doors. Brightens any room. Also used on curtain rollers to scatter healthful sunshine to every corner of room.

Ultra-Violet and Infra-Red (Heat) Rays which pass thru FLEX-O-GLASS makes plants grow much faster than when under glass. Have stronger plants for transplanting. Have earlier plants to sell. Fifteen yards of FLEX-OGLASS covers a hot bed of $135 \mathrm{sq}$. ft. Frames are lighter, much cheaper, better, and easier to handle than glass frames.

This newly discovered product is made on a strong cloth base, especially processed to make it weather-proof and beneficial for health. Just cut with shears and nail on. Lies flat. Stays bright. Lasts many seasons. Exceptionally durable. Can be patched.

1 Yard, 40c; 10 Yards, \$3.50; 25 Yards, $\$ 8.60$ 


\section{LETTUCE}

Culture-As lettuce will stand considerable freezing, it may be seeded or transplanted out of doors as soon as the soil can be worked in the spring. For a succession, sow every three weeks. It requires rich, moist soil, clean and thorough cultivation. One ounce will produce about 1,000 plants.

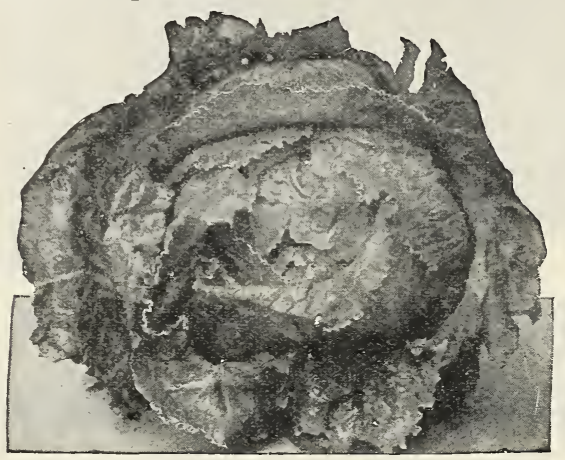

\section{SATEX SPECIAL NEIV YORK}

Early Prize Head-Forms a mammoth plant, in which even the outer leaves are crisp and tender; color bright green tinted with brownish-red. It is of superb flavor and very hardy. Pkt., 5c; oz., 15c; 1/4 lb., 35c; 1b., \$1.00.

Satex Special New York-(The standard head lettuce grown so largely in California and misnamed by the produce trade as Iceberg). Produces immense heads as solid as a cabbage. The interior is beautifully blanched, creamy-white, crisp, delicious and very tender. It is a very strong, robust growing variety. The outer leaves are attractive deep green, broad, frilled at edge. Pkt., 5c; oz., 25c; $1 / 4$ 1b., 60c; lb., \$1.75.

Big Boston-50 days. A popular market variety used largely in the South to grow winter lettuce for the northern markets. A light-green cabbage variety, slightly tinged with brown in the head. Has a fine golden buttery head. Pkt., 5c; oz., 15c; 1/4 1b., 35c; lb., \$1.00.

Hanson--A fine large-heading variety. Leaves curled on the edges, light yellowish-green in color. The head is crisp and brittle and flavor excellent. Stands warm weather extremely well. Pkt., 5c; oz., 15c; 1/4 lb., 40c; 1b., \$1.00.

Cos-Forms oblong heads of large size. Considered by many as superior to any other kind. An entire distinct type of lettuce. Sometimes called Romaine Celery Lettuce. Pkt., Б́c; oz., 20c; 1/4 lb., 45c; lb., \$1.25.

Iceberg-A large crisp lettuce, always tender. Iceberg stands hot weather remarkably. Give each head 14 inches in row. The color is light green lightly tinged with brown. Try this either for home or market garden. A little larger than Los Angeles and similar. Pkt., 10c; oz., 20c; 1/4 lb., 45c; 1b., \$1.25.

New Chicken Lettuce- $\mathrm{H}$ e $\mathrm{r}$ e is a genuine Lettuce which will yield as much or more chicken or rabbit feed as any "greens" plant. When once cut it starts to grow again. The leaves can be pulled off each stem like a kale.
Chicken Lettuce does not make a head, but sends up a stout stalk three or four feet high, just loaded with leaves. Pkt., 5c; oz., 20c; 1/4 lb., 45c; 1 lb., \$1.25.

\section{MUSTARD}

Culture-One ounce sows 75 feet of drill; four to five pounds, broadcast, an acre. For early salad, sow in February, March or April; for late sowing, September or October.

Southern Giant Curled-30 days. Leaves are large, light green with tinge of yellow, much crimpled and frilled at edges. Plant is upright and slightly spreading in growth. This variety is highly esteemed in the South for the market, as well as for the home garden on account of its vigorous growth, hardiness and good quality. Pkt., 5c; oz., 10c; 1/4 1b., 25c: lb., 60c.

Large Smooth-Leaved-30 days. An excellent sort with very large, light green, plain or comparatively smooth leaves, borne well above the ground. This sort is preferred by many, as it is more easily prepared for the table than the rougher-leaved varieties. Pkt., 5c; oz., 10c; $1 / 4$ lb., 25c; lb., 60c.

Chinese-Leaves twice the size of White English; sweet and pungent. Pkt., 5c; oz., 10c; 1/4 lb., 25c; lb., 60c.

\section{MUSK MELON}

Culture-Prepare hills, 4 to 6 feet apart, in a rich, moderately dry sandy soil, using well-rotted manure. When frost is over, plant 10 to 12 seeds in each hill about 1 inch deep, and when well up, thin out, leaving 4 strong plants to the hill. Pinch off the ends of the vines about a foot long; this will make them strong and bear more freely. Give frequent but shallow cultivation till the vines cover the ground. Dust with sifted ashes, air-slacked lime or tobacco dust to keep off insects; spray. with Bordeaux Mixture to prevent disease and improve the yield. Do not grow near cucumbers, squashes, etc. One ounce plants 50 hills; two pounds to the acre.

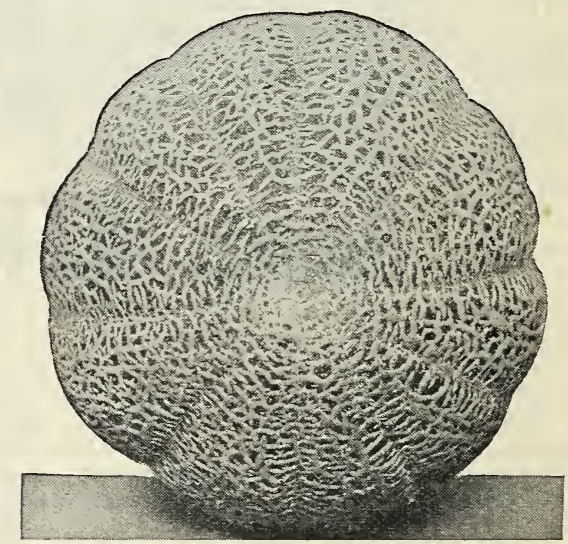

Rocky Ford, or Netted Gem-The most largely cultivated variety in use. Grown in great quantities in Colorado. Fruit is slightly oval, finely netted and slightly ribbed. Flesh thick, green, very sweet and of fine quality, and high flavor. Pkt., 5c; oz., 10c; 2 ozs, 20c; $1 / 4$ lb., 35c; lb., \$1.00. 


\section{GARDEN TOOLS}

\section{FOUR TINE SPADING FORK}

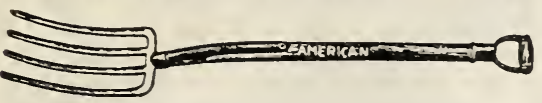

Old $\mathbf{X}$-Spading Fork. Four tempered steel tines. Strap ferrule. Iron D handle. $\mathbf{8 1 . 2 5}$ each, shipping weight, 5 lbs.

Old \$. P.-Spading Fork. Similar construction as OLDX a litle lighter built. \$1.00 each, shipping weight, 5 lbs.

Jumbo-Spading Fork. Four tempered steel tines. Iron D Handle Strap Ferrule. One of the best built forks on the market. Shipping weight, 6 Ibs.; \$2.25 each.

\section{STEEL GARDEN HOES}

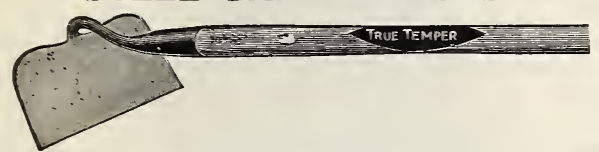

R7-Shank Pattern Standard Quality Strong and Durable, Tempered 7 inch Steel Blade. $4 \frac{1}{3}$ foot hardwood handle. 65c each; shipping weight, $3 \frac{1}{2}$ lbs.

SMO 8-Solid Socket Steel Garden Hoe. Tempered 8 inch steel blade, one piece steel socket. Selected $4 \frac{1 / 3}{3}$ foot hardwood handle. \$1.00 each; Shipping Weight, $3 \frac{11}{2}$ lbs.

yo. 2P-Weeding Hoe. Sheet Steel Blades, Iron Shanks, 3 inch Blade. Two prongs. $4 \frac{1}{2}$ foot handle. 60c ea.; shipping weight, 21/2 lb.

No. 1P-Weeding Hoe. Sheet steel blade.

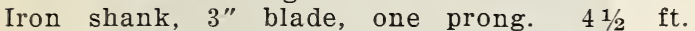
handle. Weight 21/2 lbs., 60c each.

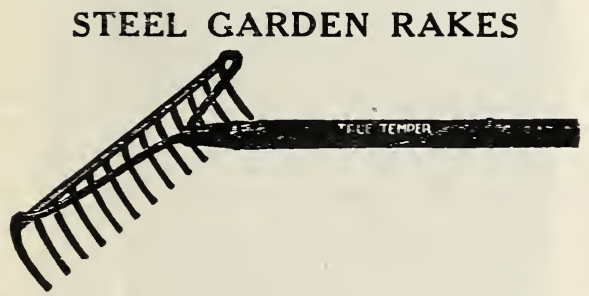

SB1t-Steel Garden Rake. 12 spring tempered teeth. Hardwood handle. 65c each, weight $2 \frac{1}{2}$ lbs.

B14-Solid bow steel rake. 14 curved teeth spring tempered. $51 / 2$ foot hardwood handle. $\$ 1.00$ each., shipping weight $3 \frac{1}{2}$ lbs.

\section{MOES GARDEN TROWELS}

No. 80 G a r d e $n$

Trowel. One piece pressed steel. Hand-

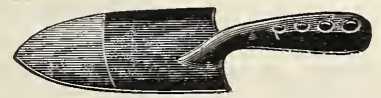

somely finished in black baked enamel. Length of blade 6 in. Ground and polished points. Each 25c, shipping weight 8 oz.

MOES TRANS-PLANTING TROWELS No. 81. Transplanting $\mathrm{T} \mathrm{r}$ o w e l. One piece pressed steel. Handsomely finish-

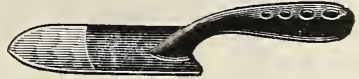
ed in black and baked enamel. Length of blade 6 in. Width $13 / 1$ in. Ground and polished points. Each 25c, shipping weight $\boldsymbol{7}$ oz.

\section{MOES GARDEN WEEDER}

No. 82. G a r d e $n$ Weeder. One piece pressed steel. Handsomely finished in

black baked enamel. Has five steel fingers, and is one of the most useful and handiest garden tools made. Ground and polished points. Each 25c, shipping weight $7 \mathrm{oz}$.

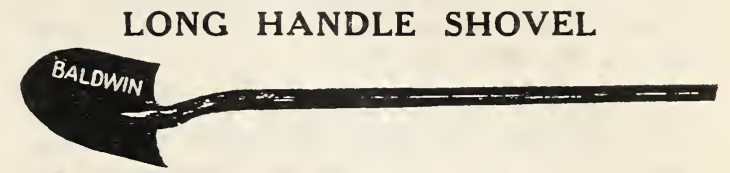

No. KL02-Knox All-No. 1 Northern Ash Handles, Blades 9 $1 / 2$ "x $11 \frac{3}{4}$ ", weight 5 lbs. each. \$1.40 each, shipping weight $6 \mathrm{lbs}$.

\section{HUDSON GARDEN PLOW}

A counterbalance plow, with a 24-inch h i g h wheel made of the very best $\mathrm{m}$ a $\mathrm{t}$ e $\mathrm{r}$ i a $l$ and most c a r e f u 1 workm ans hip. This is a good, strong, durable tool and can be used in the largest gardens. Is very $\mathrm{popular}$ and the best of its kind. Shipped with tools as shown. Weight 28 pounds. No. 242, Each $\$ 4.00$.

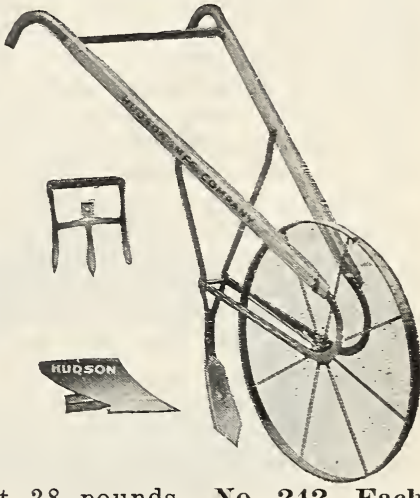

\section{CYCLONE SEED SOWER}

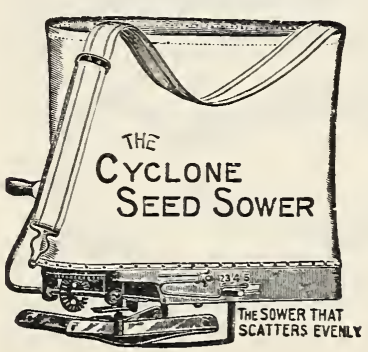

A machine of very sim ple construction. $T$ h is seeder will sow any seed that is sown broadcast, such as Oats, Wheat, Rye, Millet, Clovers. G t a s s Seeds, etc. It can be very easily adjusted to suit the seed being sown. We sell a world of them every year and our customers say they give gocd satisfaction. \$2.25 each; customers paying transportation charges. Mailing weinht 6 pounds.

\section{MASTER RAPID PLANT SETTER}

Makes transplanting a pleasure instead of a labor. Will set, water and cover in one operation, such plants as Cabbage, Cauliflower, Celery, Pepper. Tomatoes, Sweet Potatoes and Strawberries. One man can set 10,000 plants daily. You work in an upright position all the time; no stooping and no lame backs. Each, 86.00. Shipping wt. 7 lbs.

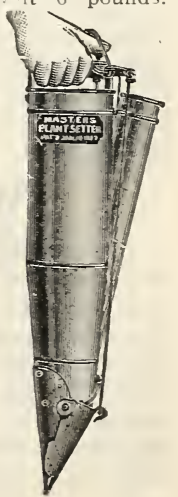


Pincapple-One of the largest and sweetest varieties on the market. It is deep ribbed and heavily netted. It is twice as large as the Rocky Ford. The flesh is deep green, and of a most cxcellent flavor. Pkt., 5c; oz., 15c; 2 ozs., 25c; $1 / 4$ lb., 40c; lb., \$1.25.

Honey Dew-The delicious honey-like flavor of this new melon has met with instantaneous public favor and created a sensation wherever used. The fruit is of large size, weighing 8 to 10 pounds each. The rind is $p=$ rfectly smooth and cream colored. The flesh is from $1 \frac{1 / 2}{2}$ to 2 inches thick, light green in color, very sweet and juicy. Pkt., 10c; oz., 20c; 1/4 lb., 50c; lb., \$1.50.

Casaba-Golden Beauty-Golden Beauty is bright yellow, about globular, with wrinkled skin, slightly pointed at stem end. The fruits are about 6 to 8 inches in diameter. The flesh is pure white and very thick. Pkt., 5c; oz., 25c; $1 / 4$ lb., 60c; lb., \$1.75.

Honeyball-It is the result of a cross between Texas Cannon Ball Cantaloupe and California Honey Dew Casaba. Resist sun scald better than most melons; a little larger in size than Rocky Ford; round and has thick wall of delicious green meat clear to the rind; small seed cavity, high sugar content and delicious flavor; a splfndid shipper. Pkt. 10c; oz., 30c; 1/4 1b., 75c; \$2.00.

Burrell's Gem-An excellent small melon of the Netted Gem type; somewhat later than that variety and a fourth larger; fruit oblong, distinctly but not deeply ribbed and well netted: flesh deep salmon, of fine quality. Pkt., 5c; oz., 15c; 1/4 lb., 40c; lb., \$1.10.

Pollock's No. 25-Best described as a salmon fleshed Rocky Ford, being identical in every way except color of flesh. It is rapidly superseding the green fleshed variety in the large melon growing districts of the South and West. Pkt., 5c; oz., 15c; 1/4 1b., 45c; lb. \$1.25.

Texas Cannonball Cantaloupe-Medium in maturity and size and of flattened, rounded shape. In flavor it is a first-class, and its dense netting makes it almost sun and insect proof, this being an immense advantage where insects are troublesome and melons liable to sunscald. Is almost all meat, seed cavity small. Pkt., 5c; oz., 15c; 1/4 lb., 40c; lb. \$1.10.

Extra Select Rocky Ford-70 days. This seed is selected out of hand-selected fruit and is superior to the ordinary run. Flesh light grees and of a delicate spicy flavor. Melon well ribbed and netted. No strain of Rocky Ford is better than this, which we offer as Extra Select. Pkt., 5c; oz., 20c; 144 1b., 70c; lb., \$2.00.

\section{WATER MELON}

Culture-Prepare hills 8 or 10 feet apart each way by working in thoroughly rotted manure, or poultry droppings-rich ground gives the plants a good start before insects attack them. When the ground is warm plant 6 or 8 seeds to the hill, covering an inch deep and, when well up, thin out, leaving three strong plants to each hill. Do not grow near pumpkins and gourds. Use the same insect reme- dies as recomm nded for cantaloupes. One ounce will plant 30 hills; 3 lbs. one acre.

Gypsy or Georgia Rattlesnake-The melon is long, smooth, distinctly striped with light, mottled and wavy dark green stripes. Flesh bright scarlet and very sugary. Pkt., 5c; oz., 10c; 14 1b., 25c; 1b., 65̃c.

Halberts Honey-Fully equal to Kleckley's Sweet, which it resembles. It is more even in outline, is blunter at the end, and the skin is of a richer, darker color. Pkt., 5c; oz., 10c; $1 / 4$ lb., 25c; lb., 65̃c.

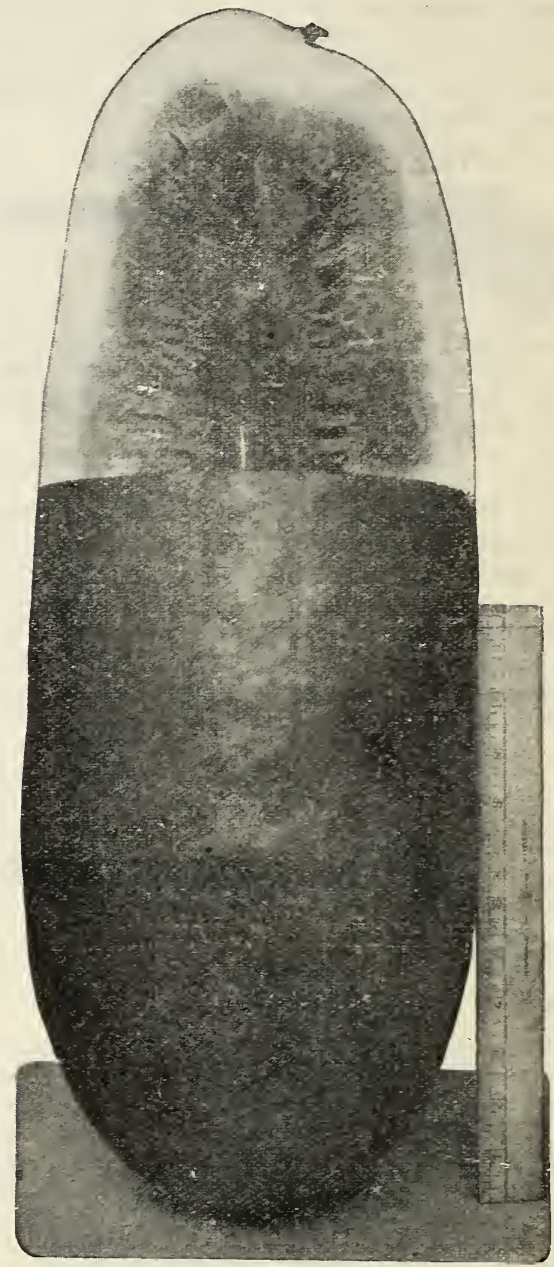

TOM WATSON

Wonder Melon-Here is a watermolon that every grower in the South will plant sooner or later. In quality of tiavor there is nothing that will compare with it. A large and long melon resembling the Tom Watson. The rind is rather thin, but tough, cutting a big red heart of the finest melon meat you have ever tasted. White seed, with few to the melon. Pkt., 5c; oz., 10c; 1/4 lb., 30c; 1b., 90c.

Dale - This splendid large melon is oblong in shape. The tough skin is a dark green color irregularly striped with lighter green. Flesh is dark red in color, fine grained, sweet and luscious. White Seed. An excellent ship- 


\section{LAW N NOWERS}

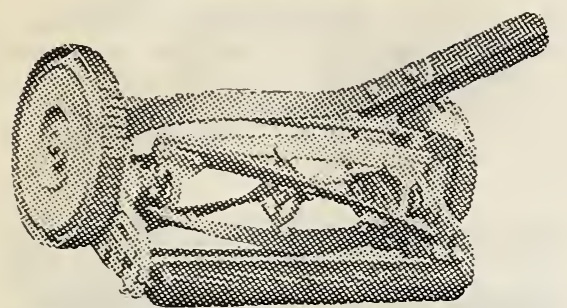

Cadet-Reel knife shaft is made of steel and runs in bronze bushings. Enclosed gearings. 8 inch driving wheel. Three crucible steel blades. Hardwood handle and roller.

14", shipping weight, $35 \mathrm{lbs} . . . . . . . . . . . . . . . . . \$ 7.50$ 16", shipping weight, 37 lbs......................... 8.00

Colonial Lawn Mower-A first class ball bearing machine which can be purchased at a price within reach of all. 8-inch driving wheels. Four blade revolving cutter insuring fineness and eveness of cut, adjustable bearings.

14 " weight 38 lbs

16 " weight 40 lbs.

$\$ 10.00$ 10.50

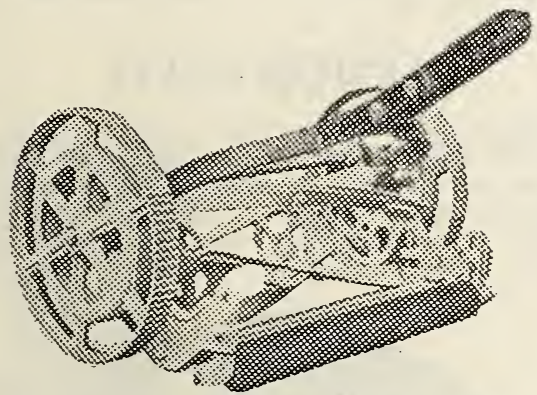

Great Southem Iawn Mower-Open side frame and drive wheels reduce the weight making it a light and easy mower to handle. Height of wheels 10 inches. Large open four blades revolving cutter. Coldwells patented adjustable ball bearings.

$14 "$ weight 45 lbs.

$\$ 12.50$

16 " weight 48 lbs.

13.50

Amazon Lawn Mower-A strictly high-grade ball bearing Lawn Mower. Large driving whsels and fine cut gears insure ease and quietness of running. Large diameter revolving cutter with five b'aces, patented adjust. able ball bearing.

14 " weight $45 \mathrm{lbs}$

16 " weight $48 \mathrm{lbs}$.

$\$ 13.50$

\section{ADJUSTABLE GRASS CATCHER}

Designaled to fit any size or style of mower and can be attached or detached in a moment. Made of strong canvas and galvanized iron bottoni. To fit any mower, 12 to 18 inch. S1.00 a a(c)!

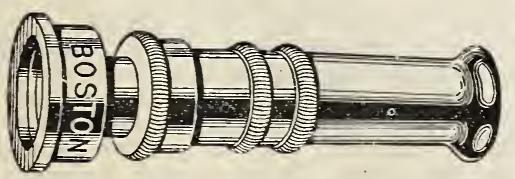

Hose Nozzle-Boston Pattern Brass Hose Nozzle. 75c each, shipping weight $10 \mathrm{oz}$.

Peoria-Same pattern as Bos'on lut lighter constyuction. Shipping weight 8 oz., 65c each.
RUBBER HOSE WASHERS

Made of good grade rubber, will fit $1 / 2$ and $3 / 4$ inch hose. 10c per dozen, weight is oz.

\section{RUBBER GARDEN HOSE}

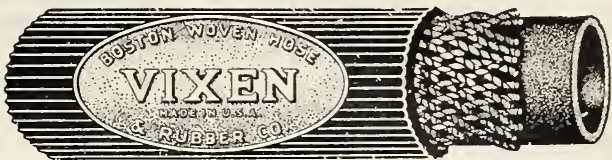

50 ft. 1/2" Comcl. 4 ply, weight 9 lbs....\$4.25 50 ft. $1 / 2$ " Leader 5 ply, weight 11 lbs.... 4.50

\section{MOLDED RUBBER GARDEN HOSE}

SFAMILSS-NON-KINKABLE-DURABLE

Made with two seamless double braided jackets over a tube of high grade rubber incased in a heavy moulded rubber outside cover. We recommend this hose for long service.

$50 \mathrm{ft}$ 1/2" Molded $12 \mathrm{lbs}$ 50 ft. $5 / 8$ " Molded 13 .lbs. 50 ft. $3 / 4$ " Molded 17 lbs. Add 25c for couplings if wanted in $25 \mathrm{ft}$. lengths.

Clincher Hose repair, weight 2 oz........... .10 Clinche: Hose coupling, weight 4 oz........ .25

\section{RING SPRINKLER}

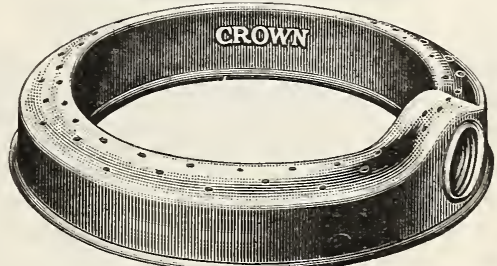

Ring Sprinkler-Made entirely of brass and distributes water evenly over a large area. 85c each, shipping weight 2 lbs.

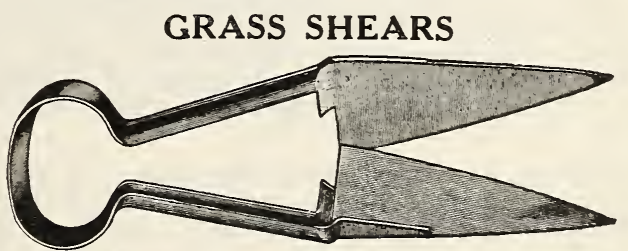

Hand forged from cutlery steel. Blades 6 inches long, ground and set and full polish. Plain Hand Forged, weight 12 oz...............35c Polished Hand Forged, weight 12 oz..........50c Keen Klip Grass Shears, weight 1 lb.........\$1.00

HEDGE SHEARS

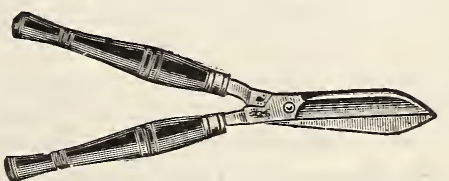

Blades hand forged from crucible steel, noched, off set shank. Tangs bolted clear through the wooden handles.

6 inch, Plain handle, weight 4 lbs...........\$1.00 6 inch, Polished handle, weight $4 \mathrm{lbs} . . . .11 .50$ 8 inch, Plain handle, weight 5 lbs.......... $\mathbf{1 . 5 0}$ 8 inch, Polished handle, weight $5 \mathrm{lbs} . . . .2 .00$ 
per. You will find our strain of this excellent melon to be the best. Limited amount of seed. Pkt., 5c; oz., 15c; $1 / 4$ 1b., 40c; lb., $\$ 1.00$.

Kleckley Sweet-80 days. A very desirable variety for the home garden or nearby markets. Fruit medium-sized, oval, and skin dark green, flesh bright red and sweet. Skin is brittle. It is the very sweet, honey-like flavor that makes it especially distinct from all other varieties. Pkt., 5c; oz., 15̌c; 14 1b., 40c; 1b., $\$ 1.00$.

Tom Watson Special-85 days. Long, dark green. More tracery on skin than Kleckley sweet, and longer. Fine variety, cream-brown seed, flesh deep red, finest flavor, no core. Often weighs from 50 to 60 pounds to the melon. One of the most popular shipping melons on the market. Pkt., 5c; oz., 15c; 1/4 lb., 35c; lb., \$1.00.

Florida Favorite-Fruit long, dark green, mottled and striped with a lighter shade. Rind thin but firm. Pkt., 5c; oz., 10c; 14a 1b., 25c; 1b., 65̆c:

New Excel-85 days. Fruit long and of mammoth size. Skin a solid green. Rind thick and tough. Neat blood-red. Contains less seed than usual. This excellent melon stands dry weather better than any melon on the market, and will make larger melons in drought than the Tom Watson. The flesh is very sweet. Pkt., 5c; oz., 10c; 1/4 1b., 25c; lb., 75c.

Alabama Sweet-80 days. A very large, long melon of excellent quality; popular in the South, where it is grown extensively for shipping. The color is rather deep green, wi.th dark, irregular striping. The rind is thin, but very tough. The flesh is bright red, fine grained and sweet. Pkt., 5c; oz., 10c; 1/4 lb., 30c; 1b., 75c.

Irish Grey-New. A valuable melon, producing more melons under any conditions than any other variety. Also a fine eating melon, and a grand shipper. The red flesh is very sweet and free from stringiness. The rind will not sunburn and will keep in excellent condition long after picking. Pkt., 5c; oz., 10c; 1/4 1b., 30c; 1b., 90c.

Citron For Preserving-90 days. A round, light and dark-stripped melon, meat greenishwhite; used for preserving only. Seed red and small. Tough rind. Pkt., 5c; oz, 10c; 1/4 lb., 25c; 1b., 75c.

\section{OKRA OR GUMBO}

Culture-One ounce will sow 50 feet of drill. Sow from March to July, one inch deep in rows four feet apart for the tall and three feet for the dwarf; thin out to a foot apart.

White Velvet-Round, white, smooth pods of extra large size produced in great abundance. Pkt., 5̃c; oz., 10c; 1/1 1b., 20c; 1b., 50c.

Perkin's Mammoth Long Pod-This variety is about three feet high, very early and productive. The pods are deep green, very long, slender, slightly corrugated, very tender and of good quality. This a desirable market as well as home garden sort. Pkt., 5c; oz., 10c; 1/4 Ib., 20c; 1b., 50c.

\section{ONION SETS}

Culture-Plant four inches apart in rows half an inch deep, and one foot between the rows, when cultivated by hand. Do not cover the sets entirely. All varieties can be set out in the fall as well as in the spring. $1 \mathrm{lb}$. plants a 60 foot row.

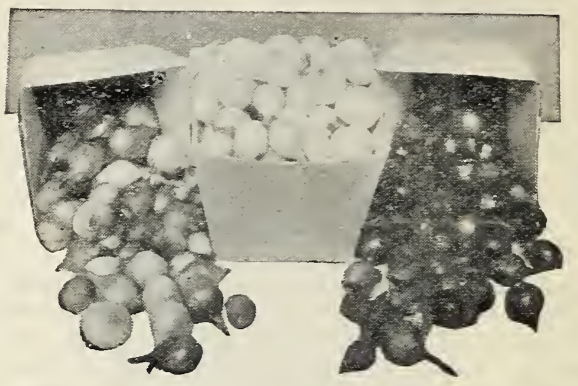

Red Bottom Sets ................... 25., 25c, Bu. \$4.00 White Bottom Sets ...............lb., 25c, Bu. $\mathbf{4 . 5 0}$ Yellow Bottom Sets .............lb., 25c, Bu. 4.00

\section{ONION SEED}

Culture-Sow seed from August to September. To make large onions from seed, as soon as the plants are as large as a goose quill, transplant four inches apart in 18-inch rows; this will increase the yield and make large onions. Five pounds will plant an acre.

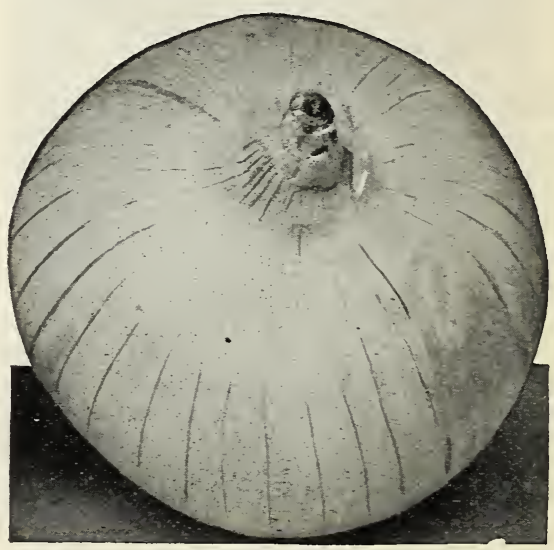

Crystal White Wax

Crystal White Wax-This is the waxy white onion seen in our market in the early spring, and it is one of the most beautiful onions on the market. It is absolutely pure white, of the finest flavor, and will always command a premium on the market. Pkt., 10c; oz., 75c; $1 / 4$ lb., \$2.00; 1b., \$5.50.

White Or Yellow Bermuda-This is the standard variety, and is grown very largely among the large Texas onion growers. It is more hardy, less affected by disease, and more prolific than the other onions. Pkt., 5c; oz., 25c; 14 1b., 85c; 1b., \$2.50. 


\section{PRUNING SHEARS}

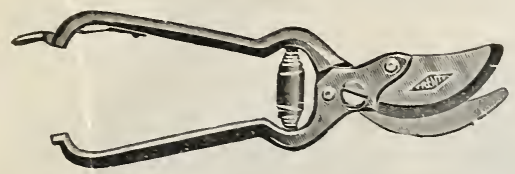

California pattern. Length 9 in. Tempered tool steel blade. Volute spring. Adjustable rachet nut. Black japanned handles. No. 313, Price each \$1.00. Weight 1 lb.

\section{PRUNING SAW}

Pruning Saw-The ideal saw for pruning, having a 15 in. curved blade. \$1.25 each.

\section{FLOWER POTS}

We pack as carefully as possible but they are shipped at purchaser's risk of breakage. Shipping charges not prepaid. Packing charges at cost.

2-inch Each

3 -inch

4 -inch

5 -inch

6 -inch

S-inch

9 -inch

10 -inch

12-inch

14-inch

16-inch

$\$ 0.03$

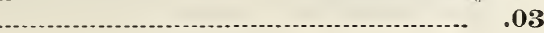

.05

. 06

.10

.20

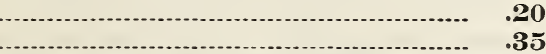

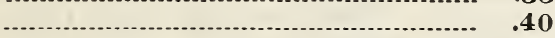

.75

1.15

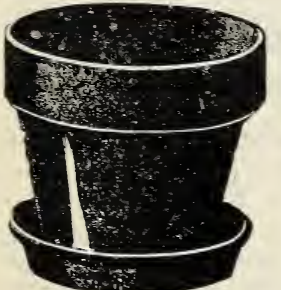

1.50

\section{FERN OR BEGONIA POTS}

They are not so deep as the regular flower pots and are used a great deal for growing ferns and Begonias in; also asparagus plants, etc.

Each

6-inch

$\$ 0.10$

8-inch

.15

10-inch

12-inch

14-inch

16 -inch

\section{STONE JARS WITH LIDS}

Splendid for preserving or pickling meats, kraut and cucumbers, etc.:

1 gallon size.

2 gallon size

$\$ 0.35$

3 gallon size

5 gallon size................................................... $\mathbf{1 . 3 5}$

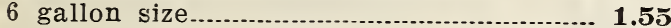

8 gallon size............................................................ 2.00

10 śallon size................................................. 2.25

NOTE: Florists and Nurserymen write us for quantity prices on flower pots, we will quote you special prices on lots of 100 or 1000 . Shipment made direct from pottery.

Spagnum Moss-Used for hanging baskets or packing plants or bulbs for shipping purposes. 1b. 30c.

\section{FLYROL}

A Perfect Fly and Insect Control; Destroys Flies, Moths, Mosquitoes, Roaches, Bed Bugs, Fleas, Chicken Mites, Lice and Their Fggs.

At last a positive control for troublesome winged insects wherever they may prove a nuisance. FLYROL will rid your home, your stable or your stock yards, of the fly, which modern science recognizes as one of the greatest sources of contagion. FLYROL will not injure dress goods, furniture, or the like. It is pleasant to smell and offers an economical and satisfactory control of flies.

\section{Prices:}

Pints

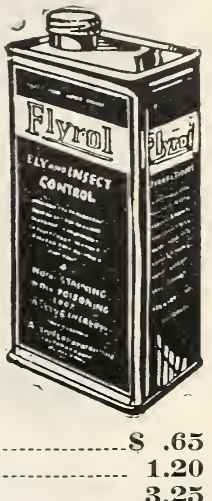

Quarts

Gallons

Can be mailed.

\section{BANNER POULTRY FENCE}

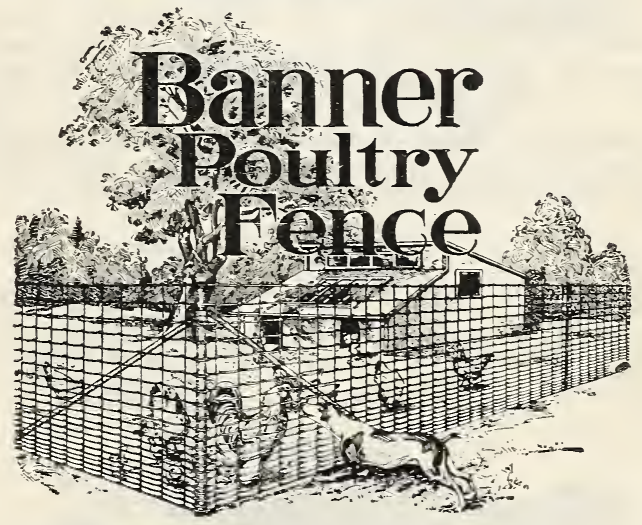

No top or bottom boards required. Can be stretched like a wire fence. Has 1 inch spacing between line wires. Stay wires 6 inches apart. An ideal chicken and rabbit proof fence. 10 rods or 165 feet to roll.

$36^{\prime \prime}$ high

$\$ 5.25$

$48^{\prime \prime}$ high

6.00

$60^{\prime \prime}$ high

7.00

72 " high

8.00

\section{AMERICAN POULTRY FENCE}

This is the regular hexagon high grade galvanized poultry netting. 1 and 2 in. mesh. 150 feet to the roll.

$\begin{array}{lll}1 & \text { ft. } & \text { high } \\ 2 & \text { ft. } & \text { high } \\ 3 & \text { ft. } & \text { high } \\ 4 & \text { ft. high } \\ 5 & \text { ft. } & \text { high } \\ 6 & \text { ft. } & \text { high }\end{array}$

1 in.
$\mathbf{3} .00$
5.25
7.00
9.25
11.75
14.00
2 in. $\$ 1.50$ 2.70 3.50 4.65 5.80 7.00

\section{SPRINKLING CANS}

Made of heavy galvanized iron.

6 quart, shipping weight 2 lbs.......... $\mathbf{8 0}$

8 quart, shipping weight $21 / 2$ lbs.............. $\mathbf{. 9 5}$

10 quart, shipping weight $31 / 4$ lbs............ 1.10

12 quart, shipping weight 4 lbs............. 1.25 


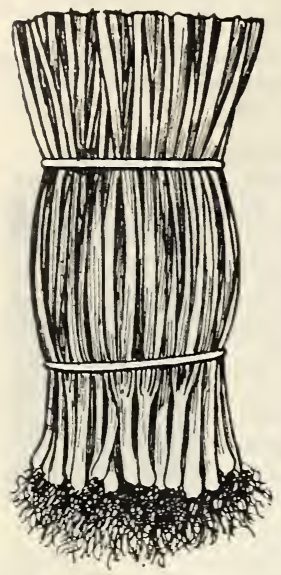

\section{ONION PLANTS}

NO PIANTS SHIPPED C. O. D.

Crystal White Wax or Yellow Bermuda

$100 \quad$.....postpaid $\mathbf{S} . \mathbf{3 0}$

$500 \quad$......postpaid $\mathbf{1 . 0 0}$

$1,000 \quad-. .$. postpaid $\mathbf{1 . 7 5}$

If you prefer to pay express charges, of $\mathrm{f}$ e $\mathrm{r}$ Onion Plants f. o. b. shipping point.

1,000 -....\$1.25 per $1 \mathrm{M}$

$5,000 \ldots .1 .10$ per $1 \mathrm{M}$

$10,000 \ldots . .1 .00$ per $1 \mathrm{M}$

$25,000 \quad \ldots . .90$ per $1 \mathrm{M}$

Write for prices on Pepper, Tomato, Eggplant \& Cabbage Plants.

\section{PARSLEY}

Culture-One ounce is sufficient for fifty feet of drill. Should be sown in February or March; in rich, mellow: soil, one-eighth of an inch deep. Parsley seed is very slow in germinating, often requires a month.

Plain Or Single-A very hardy variety. The leaves are flat and not curled. The best flavored variety. Pkt., 5̃c; oz., 10c; 1/4 lb., 25c; 1b., 75c.

Champion Moss Curled-A very finely curled, green and very ornamental variety. Pkt., 5c; oz., 10c; $1 / 4$ lb., 25c; 1b., 75c.

\section{PARSNIP}

Culture-Two ounces is enough for one hundred feet of drill; four pounds will sow an acre. Sow very thickly from March till the niddle of October, one-half of an inch deep: when plants are two or three inches high thin cut from f.ur when plants are two

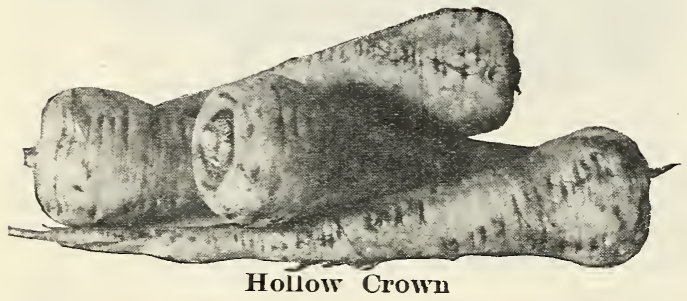

Hollow Crown-An excellent variety for the table. The roots are long, with smooth, white skin, uniform in shape, tender and of the best quality. The variety is easily distinguished by the leaves growing from the depression on top or crown of the root. Pkt., 5c; oz., 10c; 14 lb., 20c; lb., 65c.

\section{GARDEN PEAS}

Culture-Peas do best in a rich, loamy soil, soil that has been well manured the previous year. The smooth varieties can be planted as early as the ground can be worked. The wrinkled ones are not as hardy as the smooth kind and should be planted later. One pound will plant fifty feet of drill; 90 pounds for an acre. Advise inoculation with Farmogerm for best results.

First and Best - One of the earliest tall varieties, with smooth, round peas, which ripens almost, at one time. Grows two to two and one-half feet high, seed yellow-white, pods straight, short and well filled. Quality best of the smooth-seeded early varieties. Pkt., 10c; lb., 20c; 10 lbs., \$1.80; 100 lbs., \$17.00.

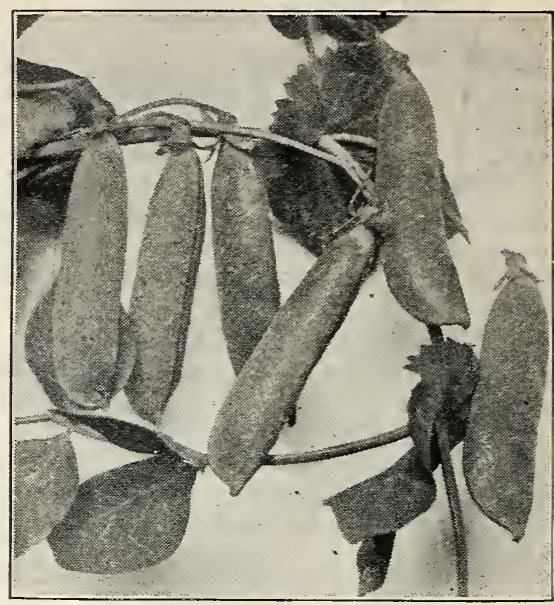

\section{Alaska}

Thomas Laxton-Excepting color of foliage and pods, in growth this is identical with the Gradus, two or three days later, but much more productive. Pkt., 10c; 1b., 25c; 10 lbs., \$2.25; 100 Ibs., \$20.00.

White Marrowfat-A very heavy yie!ding, late variety. Pods large and well filled. The dry peas are of large size and excellent for cooking. Pkt., 10c; lb., 25c; 10 lbs., \$2.25.

Alaska-A blue pea of excellent quality. The earliest of all the blue sorts. A desirable early pea for market gardeners, growing from 2 to $2 \frac{1}{2}$ feet and very productive. Plkt., 10c; lb., 20c; 10 lbs., \$1.80; 100 lbs., \$16.50.

Landreth's Extra Early-A critical gardener wants the best strain as respect earliness, size of pod. Flavor, uniformity of ripening, vigor and uniformity in habit of the plant. All these desirable qualities can be found in this pea. This type will produce peas fit for table in 44 to 50 days, according to soil and climatic conditions of the season of their growth. Pkt. 10c; 1b., 25c; 10 lbs., \$2.25; 100 lbs., \$20.00.

Bliss Everbearing-An old standard late, main crop variety. Height 3 feet. Vine and foliage sturdy and strong, dark green; pous usually in pairs, medium green, 3 inches long, straight and pointed, containing 4 to 5 light green peas of good quality; matures following Telephone. Pkt., 10c; 1b., 25c; 10 lbs., \$2.25; 100 lbs., \$20.00.

Laxtonian-A dwarf pea with large handsome pods. It is slightly earlier than Gradus maturing about the same time as Thomas Laxton. Vines medium dark green and medium heavy of foliage. Pods $3 \frac{1 / 2}{2}$ to 4 inches long, slightly curved. Will bear more abundantly at top of vines, making it easy to pick, very heavy yielder, altogether a fine pea for private and market gardners. Plkt., 10c; lb., 25c; 10 lb., \$2.25; 100 lbs., \$20.00.

Canada Field-Seed small, white; for field culture only. Height 4 feet. Vine moderately stout and medium green; pods light green, $21 / 4$ inches long, square ended, six small, light green peas in pod; matures with Telephone. Pkt., 10c; lb., 15c; 10 lbs., \$1.25; 100 lbs., \$9.00. 


\section{POULTRY SUPPLIES}

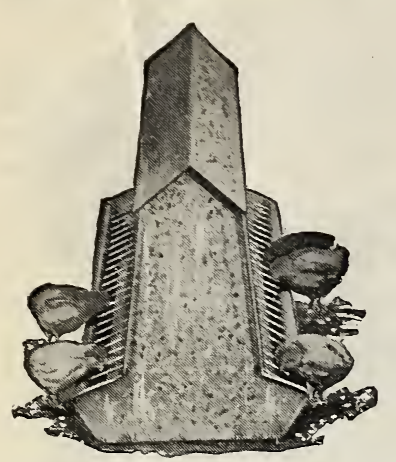

\section{OAKES CAPACITY CHICK FEEDER}

This feeder is made in three sizes, 21 inches, 35 inches and 48 inches in length. Sloping top prevents roosting and slides off for filling or cleaning. V-shaped bottom throws feed toward the outside and prevents clogging. 21-inch size has 32 feeding spaces. 35 -inch size has 50 feeding spaces. 48 -inch size has 68 feeding spaces.

Each

F- $36-(21$ inches) Weight 4 lbs. .........\$1.20

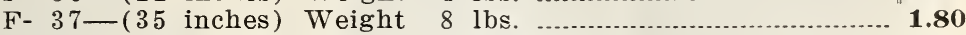

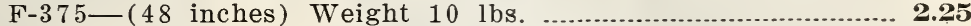

\section{LARGE CAPACITY}

F-806-Capacity 58 lbs. Mash

\section{OAKES FEED TROUGHS}

Extra heavy slide top made from best quality prime galvanized sheets accurately formed with dies; smooth turned edges on all holes. Deep enough to hold sufficient feed for growing chicks under brooders. Strictly a quality trough. Made in 3 sizes.

\begin{tabular}{|c|c|c|c|c|c|c|}
\hline & & No. of & Shipp & ing & Price & \\
\hline & Length & Holes & Weig & & Each & $\begin{array}{l}\text { Doz } \\
\mathbf{s 2 . 4}\end{array}$ \\
\hline & 12 inches & 16 & 1 & lbs. & .25 & $\$ 2$. \\
\hline & inc & 26 & $11 / 2$ & lbs. & .35 & 3.8 \\
\hline & 24 inches & 34 & 2 & lbs. & .40 & \\
\hline
\end{tabular}

Royal Buttermilk Feeders-Made of $135 \mathrm{lb}$. Charcoal Tin. Best material for feeding buttermilk and stronger than aluminum. Same construction as Royal Feed Trough.

\begin{tabular}{lllllr} 
No. & Length & \multicolumn{2}{c}{ Weight } & Each & Doz. \\
312 & 18 in. & 1 lb. & $\mathbf{3 0 c}$ & $\mathbf{\$ 3 . 0 0}$ \\
318 & 18 in. & $11 / 4$ lbs. & $\mathbf{3 5 c}$ & $\mathbf{3 . 7 5}$ \\
324 & 24 in. & $11 / 2$ lbs. & $\mathbf{4 5 c}$ & $\mathbf{5 . 0 0}$
\end{tabular}

\section{OAKES “CAPACITY” FOUNTAIN}

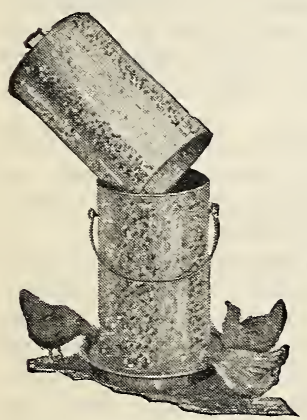

Keeps a plentiful supply of clean, fresh drinking water always available. Drinking space all around can; fountain filled from top; bail for carrying. Used $w$ i $t h$ s t a $n$ for growing fowls, or can be used without stand for baby chicks. Can also be equipped with heater for winter service.

No. F-5, 5 gal. fountain $\$ 3.75$

\section{ROUND CHICK AND PIGEON HOPPER}

Very practical; made of galvanized steel. Cone keeps feed from clogging. Trough covered with lid, which can be lowered at night, making hoppe: rat and mouseproof. Height, 14 in.; diameter of hopper, $7 \frac{1}{2}$ in.; diameter of pan, 12 in.

No. F-76 without trough

lid, wt. 5 lbs. $\$ 1.25$

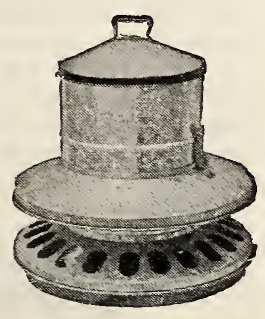

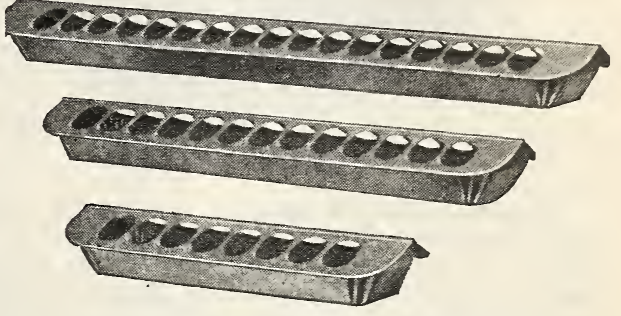

\section{OAKES NEVER DRY WATERER}

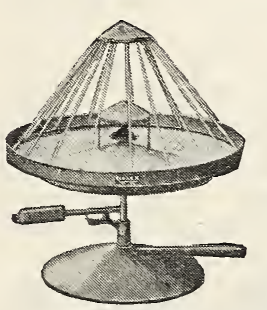

Automatically controlled flow of water. Easily attached to hose or w a t e r pipe. Will take care of large or small flock. Nothing to get out of order. Fowls can not scratch dirt or litter into it, nor get into the water, or roost on this device.

\section{"SUN-LITE" OAKES}

$\$ 3.90$ SPROUTER

Made of galvanized iron, each 18-inch perforated pan or tray can be removed separately. No lamp or fuel required. Put in the oats, moisten a little daily and in three or four days you can feed sprouts. Sections and trays can be purchased to increase capacity as desired.

No. F-63, 6-tray, each.......\$6.50

\section{OAKES IMPROVED HANDY HOPPER}

$\mathrm{H}$ i n g e d lid keeps out rats, $m$ i c e a $\mathrm{nd}$ dirt. Swinging front, adjustable to any kind of dry $\mathrm{m}$ a s h, eliminates clogging. Hopper 15 in. high, $4 \frac{1}{2}$ in. wide and made in four lengths.

No. F-12, length 12 in.......................................

No. F-13, length 18 in...........................25

No. F-14, length 24 in............................. $\mathbf{2 . 7 5}$ No. F-15, five compartments, length $36^{\prime \prime} \mathbf{3 . 9 0}$ 


\section{PEPPER}

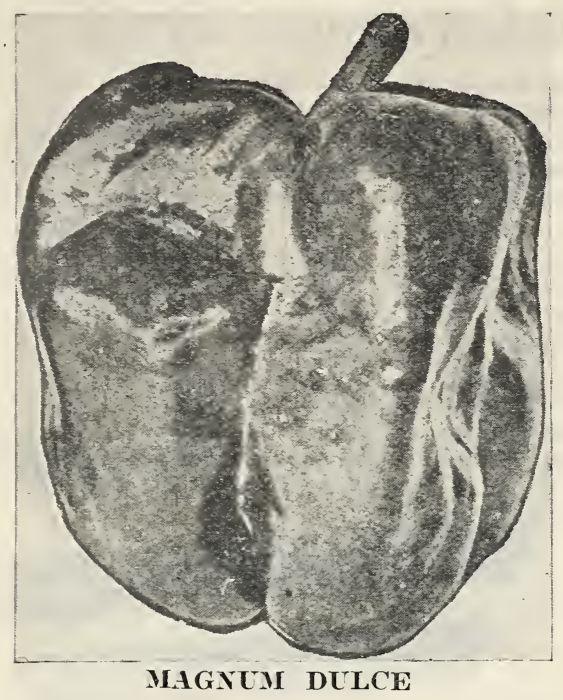

Culture-Sow in box or hotbed in January and February; cover seed about one-half inch deep, and transplant outside in April, 18 inches apart, in $2 \frac{1}{2}$ or 3 -foot rows. When the ground becomes warm, sow seed outside and transplant when large enough. Give free cultivation and keep free from weeds. One ounce will produce about 1,000 plants.

Worldbeater-This is without doubt, the finest introduction in peppers in ages. It is a cross between Chinese Giant and Ruby King, having the shape of the Ruby King, except that it is broader at the pointed end and almost the size of the Chinese Giant. It is far more prolific than Chinese Giant. Pkt., 5̃c; oz., 40c; 1/4 1b., \$1.25; 1b., \$3.50.

Chinese Giant-Plant dwarf, fruit of mammoth size, very broad, but rather short. It is very late and a rather shy yielder. Popular on account of its large size and mild flavor. Our stock is pure and is as good as can be obtained. Pkt., 5c; oz., 65c; 1/4 lb., \$1.75; 1b., \$5.50.

Ruby King-This variety grows to an extraordinary large size. When ripe, a handsome, bright, ruby-color; remarkably mild and pleasant to the taste. For stuffing, no other variety can equal it. Pkt., 5̌c; oz., 35c; 144 1b., \$1.00; Ib., \$3.00.

Magnum Dulce-140 days. The largest of all the Sweet Peppers, sometimes growing six to seven inches in length, and five to six inches in diameter. Very prolific. Plant about three feet high. Fruit deep green when young, crimson when fully matured. Flavor very mild. The most popular variety for market gardeners, and also for home gardens. Pkt., 5c; lb., 50c; $1 / 4$ lb., \$1.60; lb., \$5.00.

Pimiento or Perfection-A medium early, prolific, perfectly mild variety with extremely thick flesh. On account of its thick flesh it will hold up for a long time and is an excellent sort for canning whole. Pkt., 5c; oz., 40c; 1/4 lb., \$1.25; lb., \$3.50.

\section{HOT OR PUNGENT VARIETIES}

Red Chili-A rather small, bright red variety, about two inches long and pointed. The poos are used in making Chili sauce, and are very pungent and hot. Pkt., 5c; oz., 40c; 1/4 lb., \$1.25; lb., \$4.00.

Long Red Cayenne-110 days. A strong, pungent variety, having well pointed fruit, which is bright scarlet when ripe. A very popular variety. Pkt., 5̌c; oz., 40c; 1/4 lb., \$1.25; 1b., \$3.5̃o.

\section{PUMPKIN}

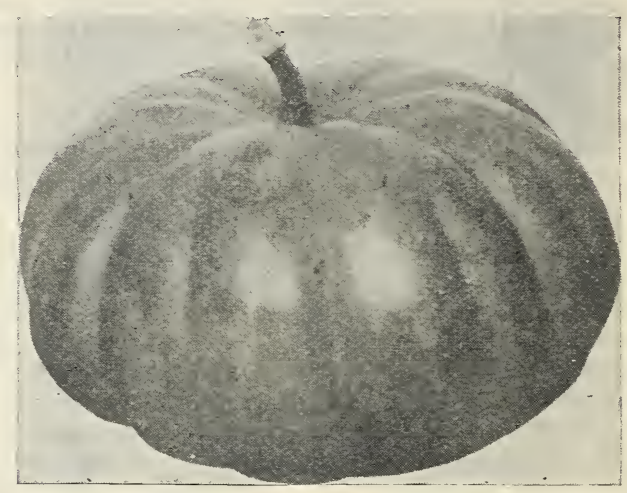

Large Cheese Pumpkin

Culture-Plant from April to September in hills eight to ten feet apart; prepare land as you would for melons. When planted in corn, plant every fourth row at the same time you plant the corn; three pounds wili plant an acre.

Cheese-65 days. A very good table variety. Shape fiat, like a cheese box; a good keeper. Often 15 inches across the top. Pkt., 5c; oz., 10c; 1/4 1b., 30c; 1b., 90c.

Kentucky Field-90 days. Sometimes called Large Cheese. A very large, flattened pumpkin, averaging about two feet through. When ripened the skin is a rich cream color. Flesh yellow and of fine quality. Pkt., 5c; oz., 10c: $1 / 4$ lb., 25c; 1b., 75c.

Pie Pumpkin-65 days. A small round, yellow sort, with fibre pinkish netting. Flesh is thick, sweet and of excellent quality. Pkt., 5c; oz., 10c; 1/4 lb., 30c; 1b., 90c.

Green Striped Cushaw-70 days. Fruits very large, white crooked neck. Color, creamy white, irregularly striped or traced with green. Flesh light yellow, very thick, rather coarse but sweet. This sort is very productive and popular in some sections. Pkt., 5̃c; oz., 15c; 14 lb., 40c; lb., \$1.00.

Marrow-A very large round, flat pumpkin, brilliant vermillion orange in color, and the handsomest pumpkin in existence. The flesh is very thick and solid and is bright orangeyellow in color. The seed cavity is amazingly small and on this account there is but little seed, which means that it will never be a cheap variety. Pkt., 10c; oz., 15c; $1 / 4$ lb., 45c; lb., $\$ 1.25$.

Use Semesan to increase the germination of Pepper, Pumpkin, and all other garden seeds. 


\section{MOES BABY CHICK FEEDS}

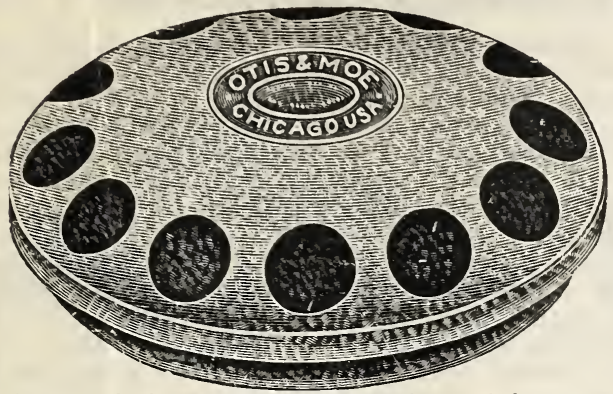

A great feed saver, and can also be used for water or milk. Accurately stamped with dies. Top fits snugly, yet is easily taken off for filling and cleaning.

No. 11. Diam. 6 in. with $\&$ holes, each......................... Shipping Weight 1 Pound

No, 12. Diam. 81/." with 12 holes, each. Shipping Weight 1 Pound

$25 \mathrm{c}$

MOES DOUBLE FEEDING TROUGH

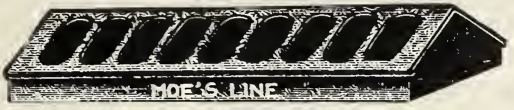

Made of best quality galvanized iron, accurately stamped with dies. No sharp or rough edges to injure the chicks Iade in three sizes.

No. 58-Length 12 in., weiglit $1 \frac{1}{4}$ lbs., each

No. 59-Length 18 in, weight $1 \mathrm{r} / 2$ lbs, each

No. 60 -Length 2.4 in., weight 2 lbs., each...............................65c

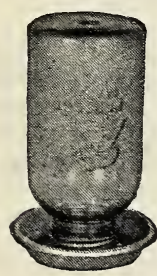

\section{OAKES JAR FOUNTAINS}

Made from 2 materials, extra heavy gal vanized iron, charcoal tin. No solder used; very substantial pan with heavy rolled edge; electric welded center; can be used for chick feed as well as water Charcoal tin. Fountain is designed for dispensing buttermilk and sour milk especially.

We do not furnish theglass jars.

No.

F69 Galvanized

Each Shipping Weight Doz.

00 Charcoal Tin

$10 \mathrm{c}$

$8 \mathrm{oz}$.

$\$ 1.00$

\section{OAKES ALL GALVANIZED FOUNT}

Nade from heavy galvanized iron in two pieces. Top made with handle for carrying. Base pulls off to fill. Pressure of air and grooves in pan hold weight of water and fountain may be carried by handle without fear of spilling.

No. 31-1 gallon. Shipping weight 4 lbs., each

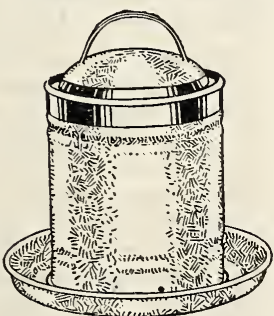

OAIES EGG SCALE

In many localities eggs are now being bought and sold according to weight. Indiana has been using $22 \mathrm{ozs}$. to the dozen eggs; just right for our No. F-53, while No. F-54 will fit any standard. Oakes Egg Scales are durable (constructed of steel) and simple; no springs-nothing to get out of order.

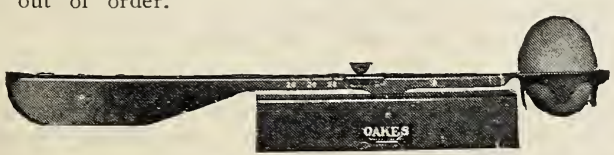

No. F-54-Oakes Graduated Egg Scale. Each..............\$ .75

\section{BUTTERMILK FEEDER}

A perfect Feeder for sour milk, buttermilk, w a t e r, hard grain or grit. The container is made of aluminum, the only metal in which sour milk can be fed with safety. It is rust-proof a $\mathrm{n} \mathrm{d}$ non-corroding. $\mathrm{T} \mathrm{h} \mathrm{e}$ Handy is adjustable, simple to operate and durable. Ea. 40c. Shipping weight $1 \mathrm{lb}$.

(Glass jar not included)

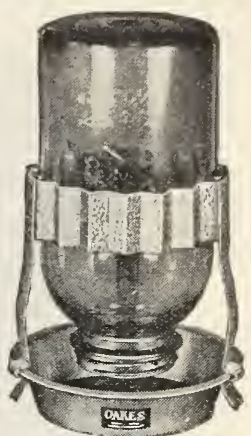

\section{OAKES BOTTOM FILLED FOUNTAIN}

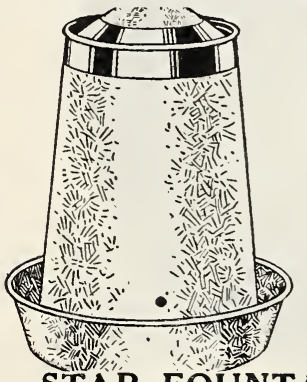

An inexpensive fountain, made from heavy galvanized iron. Two piece cone shape, neatly striped with green around top. Easily filled and cleaned.

1-quart size, 30c each, shipping weight 1 pound.

2-quart size, $40 \mathrm{c}$ each, shipping weight $1 \frac{1}{2}$ pounds.

1-Gal. size, 50c each, shipping weight 12 pounds.

3-Gal. size, \$1.25 each, ship-

\section{STAR FOUNTAIN AND FEEDER}

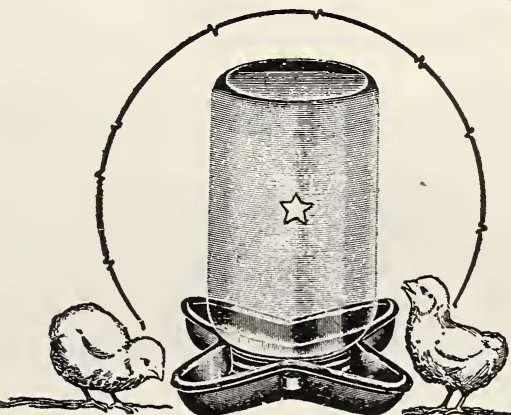

Made of a single piece of heavy metal. No solder, no seams, no loose parts, chicks can not drown. Fits any (Glass jar not included.) Each 10c. Shipping weight ounces.

\section{STAR BUTTERMILK FEEDER}

Made of Bright Charcoal Tin Plate, which is not affected by milk acids. The same material as is used in milk cans, cream separators, etc. Makes an absolutely safe and sanitary feeder for butternilk and sour milk. Each...............12c

\section{STONE DRINKING FOUNTS}

1-Gal.-Stone Drinking Founts ........ 25c each 2-Gal---2 Piece Shipping Weight 8 Lbs.

Shipping Weight 17 Lbs.

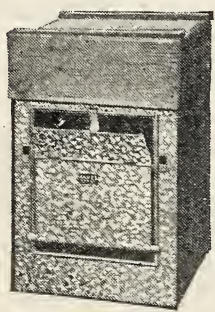

\section{OAKES SINGLE FRONT FOR TRAP NEST}

You can use this front to make a trap nest out of any ordinary orange box, small dry. goods box, etc. Entirely practical but inexpensive.

Opening $9 \times 10^{1 / 2}$ in.

No. F-59, each .........................35c 


\section{GENUINE MAINE GROWN SEED POTATOES}

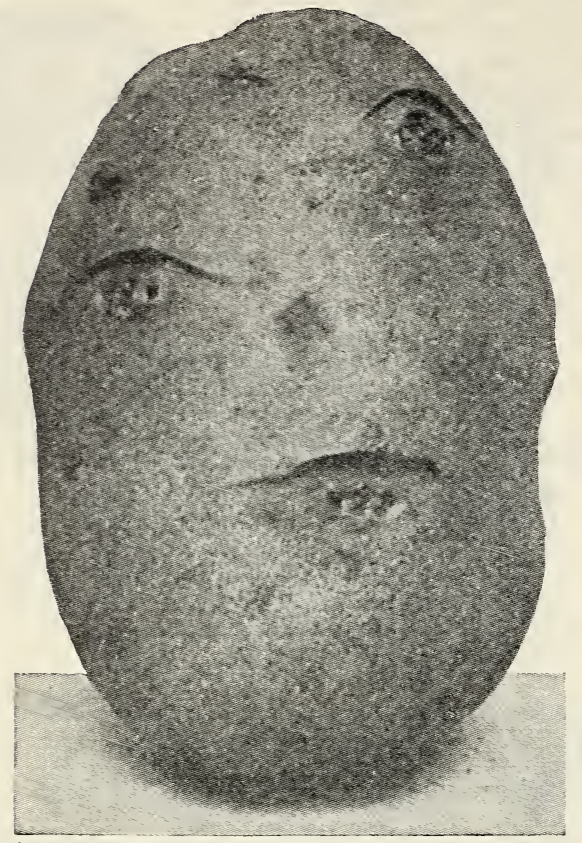

Irish Cobbler

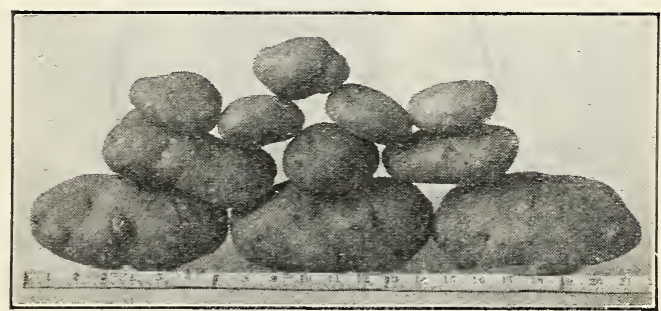

These fine potatces were dug from a single hill of SEMESAN BEL-treated seed

\section{DISEASE-FREE POTATOES}

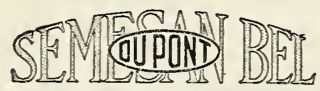

Makes Seed Potatoes Healthy

Semesan B el, prep a $r$ e d especially for the seed disinfection of white and sweet potatoes, in addition to its advantages of $\mathrm{d} u \mathrm{~s} t$ application, is the only disinfectant which can be applied a s a 1 lb. $\$ 1.75,5$ lbs. stantaneous dip is 50 lbs, $\$ 72.50$. $\$ 37.50$, sweeping the country/Ibs. $\$ 140.00$.

SEN1) FOR FREE POTATO BOOKLET
Culture-Potatoes can be grown in any soil provided it is well drained, but if grown on sandy, rich soil they will be of better quality than if planted on clay soil. The sets should be planted from 4 to 6 inches deep, according to the time of planting, in rows 3 feet apart and 16 to 18 inches in the rows. If planted $11 / 2$ by 3 feet there will be about 9,700 hills in one acre, and it will take between 600 and 700 pounds, according to the size of the sets to plant it. At 3 by 3 feet one-half the quantity is sufficient. Unless you have a rich soil would advise fertilizing with a mixture of $75 \%$ Acid Phosphate and $25 \%$ Cotton Seed Meal, using same at the rate of $600 \mathrm{lbs}$., to the acre.

Irish Cobblers-This variety is one of the most reliable and popular of the early varieties. It is of handsome creamy-white color and of excellent quality, making it most desirable for the best trade. It is a vigorous grower, ripens uniformly and a good keeper; in short, one of the best all-around early petatoes on the market. Peck 90c.

Bliss Triumph or Red Bliss-This is the most standard red variety. in the Southern States. It is very early and matures quickly. The potatoes are round and uniform in shape, eyes slightly depressed and a beautiful bright red color. It is very hard, and not susceptible to disease. Peck 90c.

\section{RADISH}

Culture-One ounce will plant j0 feet of drill. The tenderness and sweetness of radishes are greatly dependent upon the rapidity of their growth. Sow out doors; half an inch deep; from February to October; broadcast or in drills.

Early Scarlet Turnip, White Tipped-One of the most popular and attractive short varieties. It is globe shaped, bright rose carmine with bottom and tip clear white. Stems and leaves are small. Very valuable for forcing, as well as for the garden and market. Pkt., 5c; oz., 10c; 2 ozs., 15c; $1 / 4$ lb., 20c; lb., 60c.

French Breakfast-A quick growing, small, olive-shaped radish about one and one-half inches long by five-eights to three-fourths of an inch in diameter when fully grown. The color is beautiful deep rose scarlet except a little clear white about the tip. This is an excellent variety for planting outdoors for the home garden. Its small tops and earliness make it also desirable for growing under glass. Pkt., 5̌c; oz., 10c; 2 ozs., 15c; $1 / 4$ lb., 25c; lb., 75 c.

Wonderful Half-Long Scarlet-23 days. So rapid in growth as to develop perfectly in 23 days. Grows about $21 / 2$ inches long, contrasting from a broad shoulder to a sharp point; very symmetrical and uniform in shape; color a bright scarlet, and altogether a gem. Pkt., 5c; oz., 15c; 1/4 lb., 30c; 1b., 90c.

Chartier Or Shephard Radish-A variety of Long Scarlet. Deep crimson at top, almost white at bottom. Plit., 5c; oz., 15c; 1/4 1b., 30c; 1b., 90c. 


\section{AUTOMATIC SUPER-HEATER OIL BURNING BROODERS}

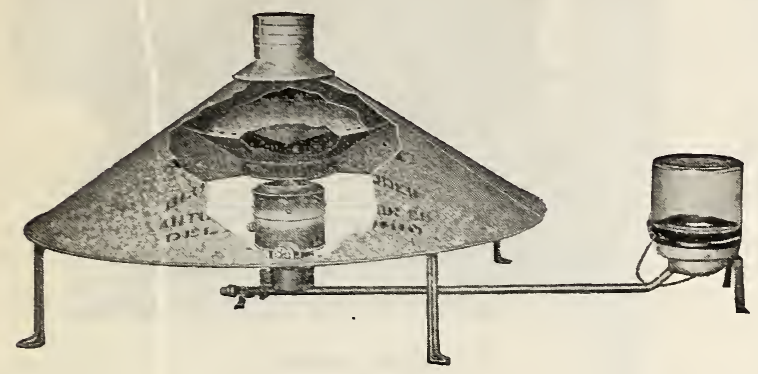

The most dependable brooder yet devised. The super heater attached inside the canopy reflects all heats to backs of baby chicks. Self feeding, economical and absolutely safe.

More or Less Heat as you desire-Far less Fuel Consumption-as easily operated as a House lamp-no thermostats or valves - self-feeding and absolutely saffe.

\begin{tabular}{|c|c|c|}
\hline IL-BURNING & No. 1 & No. 2 \\
\hline Capa & 20 & 350 \\
\hline eter of & $34^{\prime \prime}$ & $42^{\prime \prime}$ \\
\hline ipping weig & & 60 lbs. \\
\hline
\end{tabular}

The Automatic Super Heater is Equipped on the No. 1 and No. 2 for S3.50 extra.

\section{AUTOMATIC COAL BROODERS}

1. Double draft system automaticaly controlled.

2. Larger chick brooding capacity.

3. Stove larger in size to radiate more heat.

4. Larger coal capacity-less attention required.

5. 5-inch store pipe flange.

6. Larger size canopy-56-inch.

7. Larger grade to insure a more steady flame.

8. Burns soft coal efficiently.

9. Gas-burning Brooders as Standard equipment.

10. Larger Cylinder's and Fire-bowls.

No. 5-42" Hover, 500 chick, 80 lbs.

No. 7-52" Hover, 1000 chick, 100 lbs................ 21.50

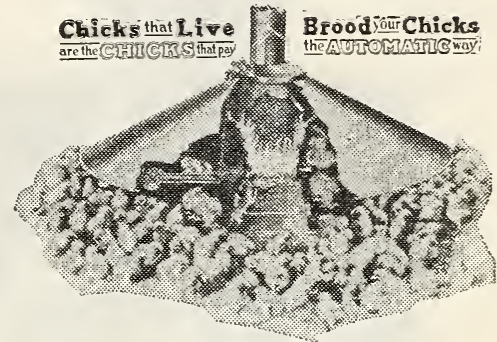

Write for Full Descriptive Catalog.

\section{BUCKEYE INCUBATOR AND BROODER EXTRA PARTS}

\section{FOR INCEBATORS}

Buckeye Universal Thermometer.

Holders for Old Style Thermometers

$\$ 1.00$

Lamp Bowls for all Incubators................. 1.00

Lamp Burner No. 35 (For Incubators Nos.

$1,2,14$ and 16)

.75

Nos. $3,4,5$ and 17 )

Lamp Burner No. 330 (For Incubators)

Lamp Chimneys for all Incubators............

Lamp Wiciks for all Incubators, per dozen

Connecting Rod and Nut for Regulators

Egg 'Tester

Drain Cap for Incubator Tanks.

Filler Cap for Incubator Tanks.

Filler Cap for Lamp Bowls.

1.00

.50

.35

.50

.50

.25

.35

Extra Tanks for Buckeye Incubators-

For Incubator No. 1 (Copper).

For Incubator No. 2 (Copper)

.25

For Incubator No. 3 (Copper) ..............12.00

For Incubator No. 4 (Copper) ....................

For Incubator No. 5 (Copper) ...........22.50

For Incubator No. 14 (Copper) ............. 6.00

For Incubator No. 16 (Copper)

For Incubator No. 17 (Copper) ...................50

\section{FOR OIL BURNING BROODER}

Brooder complete, less canopy, for No.

$$
27-\mathrm{A}
$$

Brooder complete, less canopy for Nos.

$28-\mathrm{A}$ and $29-\mathrm{A}$

$\$ 1350$

Canopy complete for No. 27-A.............. 6.50

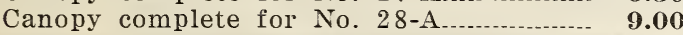

Canopy complete for No. 29-A ................. 11.00

Burner with Wick for No. 27-A............... $\mathbf{5 . 0 0}$

Burner with Wick for Nos. $2 \delta-A$ and $29-\mathrm{A}$
Outside Enameled Chimney for No. 27-A.- 1.50 Outside Enameled Chimney for Nos. 28-A

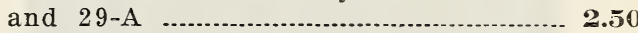

Inside Perforated Chimney for No. 27-A ... .50

Inside Perforated Chimney for Nos. 28-A and 29-A

Central Perforated Chimney for No. 27-A .50

Central Perforated Chimney for Nos. $-8-\mathrm{A}$ and 29-A

Oil Jug with Automatic Valve........................5

Automatic Valve for Oil Jug........................

Supply Pipe with Oil Cup and Stand......... 6.50

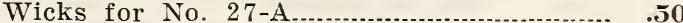

Wicks for Nos. 28-A and 29-A ................... .75

Leg for Canopy .......................................... .50

\section{FOR COAL BURNING BROODER}

Wafer Thermostat (Fit all sizes) ............. . .50 FOR PORTABLE BROODER

Thermometers (Tested)

NOTE-We carry above parts in stock and can make immediate shipment. For parts not listed will have them forwarded to you direct from factory.

\section{RAISE}

More and Better Baby Chicks By Proper Feeding.

We Recommend SUPERIOR Chick Starter and Growing Mash Containing Dehydrated Orange and Peel

See Page

Order Your Requirements Now To Have A Supply On Hand When Those Fluffy Beauties Arrive. 


\section{RADISH (Continued)}

Scarlet China-One of the best of the winter varieties. The roots are cylindrical, or largest near the bottom, stump rooted or blunt at both ends. The skin is smooth and of a bright deep rose color. Pkt., 5c; oz., 10c; 14 1b., 25c; 1b., 75c.

Long White Vienna-A very fine, long, white variety; quick growing and ready for use when very young. The flavor is mild and sweet. Plit., 5c; oz., 15c; 1/t 1b., 30c; 1b., 90c.

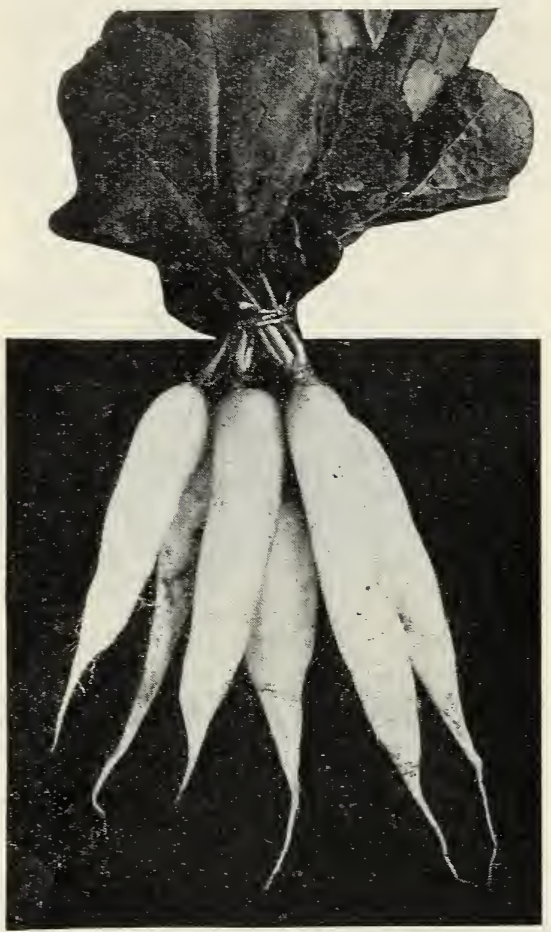

White Vienna

Long Black Spanish-70 days. One of the latest and hardiest long garden radishes; especially adpated for winter use. The roots are long, thick, almost black, somewhat wrinkled. The flesh is white, of firm texture, decidedly pungent, but well flavored. The roots when matured are usually seven to nine inches long by two or three inches in diameter at the thickest part. Pkt., 5c; oz., 15c; 1/4 lb., 30c; lb., 90c.

\section{SPINACH}

Culture-For early spring use, sow in February and March; in drills, one inch deep; two feet between the rows, or either broadcast; have well fertilized. Two ounces will sow 100 feet of drill; 10 to 12 pounds, one acre. For winter and spring use, sow from September to December.

Bloomsdale-10 days. As an autumn sort it is superior to all others; but in the spring is inclined to shoot early. The leaves are twisted and bloated, giving them, when ready for shipment, an elasticity adapting them for transportation to long distances and at the same time giving the crop large measuring qualities. Pkt., 5c; oz., 10c; 1/4 lb., 15c; lb., 30c.

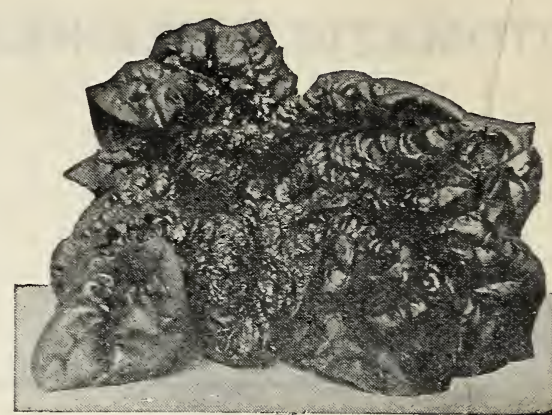

Bloomsdale

New Long Standing Bloomsdale-Has all the good points of the above, in addition, it will withstand the summer heat and does not go to seed. Pkt., 10c; $1 / 4$ 1b., 20c; 1 lb., 40c.

Broad-Leaved Flanders - One of the most vigorous and strong growing varieties. The leaves are nearly round, uniformly deep green, quite thick and slightly crimped in the center. Pkt., 5c; 1 oz., 10c; 1/4 lb., 15c; 1 lb., 30c;

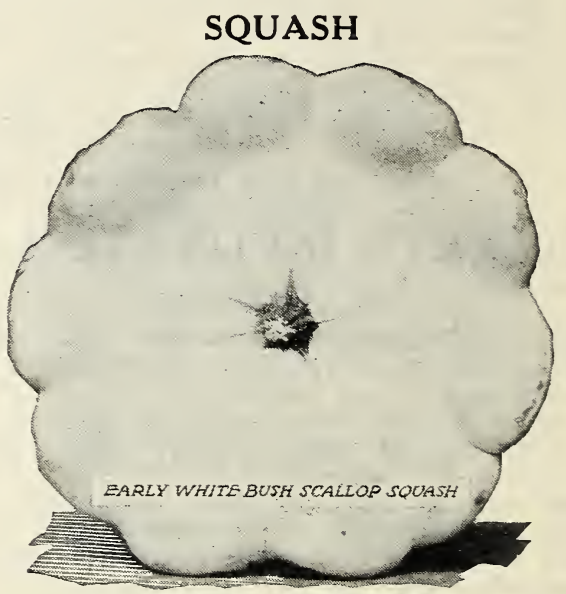

Culture-Prepare soil in same manner as for nelons; make hills three to four feet apart. Plant one inch deep; eight to ten seeds to the hill; one ounce will plant 25 hills; three to four pounds to an acre.

Early White Bush Scallop-50 days. A very early variety, with flat, creamy white scalloped squashes, 4 to 6 inches in diameter. The vine is bush in habit and rather dwarf. This variety is the common "patty pan" squash. Pkt., 5c; oz., 15c; 1/4 lb., 35c; lb., \$1.00.

Mammoth White Bush Scallop-60 days. An early maturing, somewhat flattened, scalloped bush squash of largest size, and the handsomest of the summer varieties for home garden and market. The vines are vigorous and productive. Pkt., 5c; oz., 15c; $1 / 4$ lb., 40c; lb., \$1.10.

Yellow Crookneck-The well known summer variety. Fruit long, skin very fine and tender when young. Pkt., 5c; oz., 15c; 1/4 lb., 40c; 1b., \$1.10. 
TESTED INCUBATOR THEROMETER

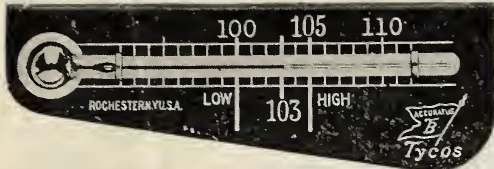

Tycos Incubator Thermometer, wt.

6 oz.

Buckeye In cubator Thermometer, wt. $\&$ oz.

\section{BROODER THERMOMETER}

No. 129-Genuine "Tycos" thermometer To be inserted through a hole in the top of the brooder so the bulb is in the actual brooder temperature, and the scale is outside for easy reading. Wt. 6 oz. $75 c$

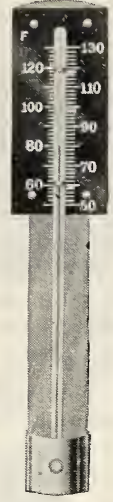

\section{NAPTHALENE NEST EGGS}

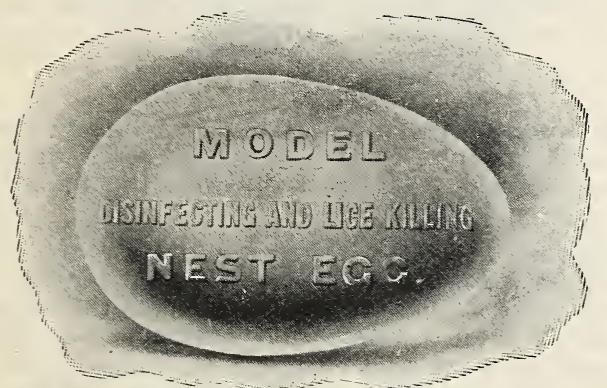

This egg is used not in reality as a nest egg, but is put into the nest to remove and kill the lice. If one of these nest eggs is placed in a nest with the nesting material, it will remove all vermin, if put in a corner of the nest under the setting hen, it will keep hen free from lice and mites.

Weight 2 lbs., per doz. 75c.

\section{GLASS NEST EGGS}

Made of white porcelain, natural in appearance, and uniform in size. Will not easily break. They induce the hen to lay where she should--in the nest. Per doz. 30c; weight $1 \mathrm{lb}$.

\section{CHALK NEST EGGS}

Made of white chalk, uniform size, not easily broken, weight 2 lbs...........per doz. 50c

\section{SURE-TRIP TRAP NEST FRONT}

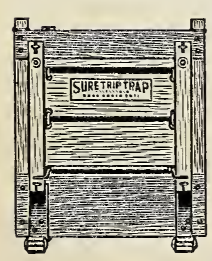

The Practical Trap Nest is a profitable addition to every p o u 1 t ry plant, because it weeds out the drones and cuts down feed bills for the man who wants to keep only those birds that produce. Strongly built of good lumber, as light in weight as consistent with strength and durability - with a trap that works noiselessly and surely. ..Each 35c; 100 $\$ 30.00$, weight 1 lb. each.

\section{INCUBATOR LAMP WICKS}

Made of felt. The best wick to use in your incubator lamp. State width of wick when ordering. Each 5c; doz. 50c; weight 2 oz.
PATTERSON AND YOUNG MOISTURE GUIDE

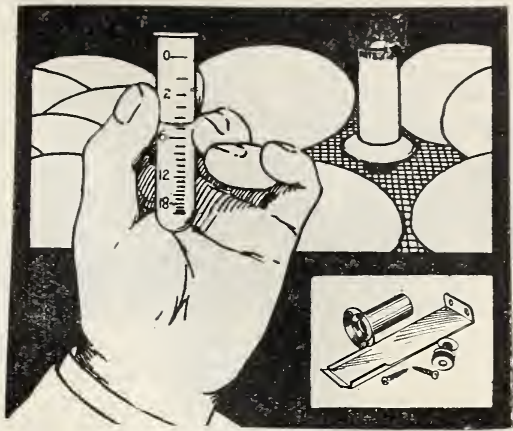

This moisture guide solves the moisture problem with your incubator. The holder is fastened to the egg tray and the guice is filled with water to the top line. The graduated scale shows how much moisture should evaporate from the egg each day. If evaporation is too fast, moisture should be added; if too slow, more air should be given. Full directions go with each guide. Attachments are included for all turning trays. Every owner of an incubator should have this moisture guide. Weight 3 oz., Each \$1.00.

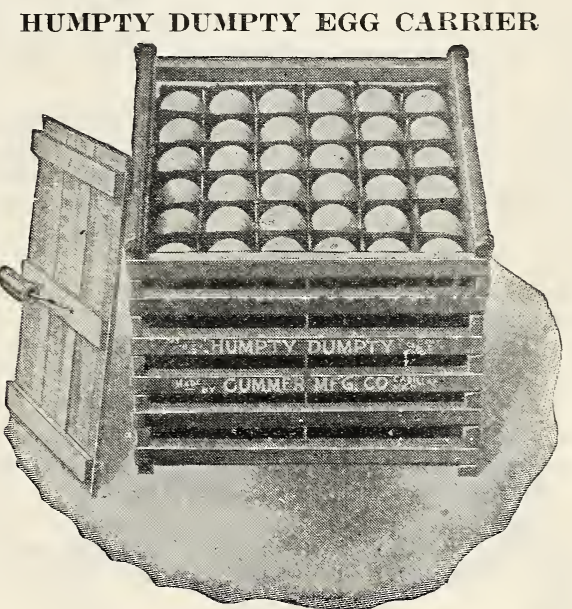

A very light, strong and convenient egg crate and carrier. Made of hard wood slats securely fastened. The lid with handle, springs into position when crate is filled. Collapsible. 12 dozen size, 90c; Parcel Post weight $7 \mathrm{lbs}$.

YARD EGG BOXES FOR RETAIL TRADE

This is an ideal box for the retail e $g \mathrm{~g}$ trade holding 1 dozen, presenting the $\mathrm{g}$ o o d $\mathrm{s}$ to the customer in an attractive package with the minimum amount of trouble for $\mathrm{th}$ e selle r.

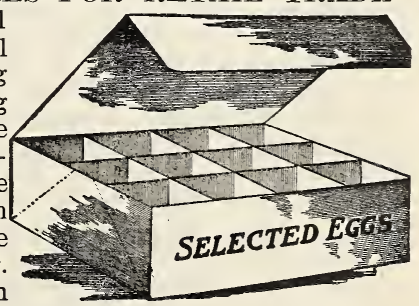
in very compact shape.

$3 \times 4$ Eagle, weight 12 lbs., per $100 \ldots \ldots . . \$ 1.00$ $3 \times 4$ Eagle, weight 105 lbs., per $1000 \ldots \mathbf{8 . 5 0}$ $2 \times 6$ Seminole, weight 17 lbs., per $100 \ldots . \mathbf{1 . 5 0}$ $2 \times 6$ Seminole, weight 155 lbs., per $1000 \mathbf{1 3 . 5 0}$ 


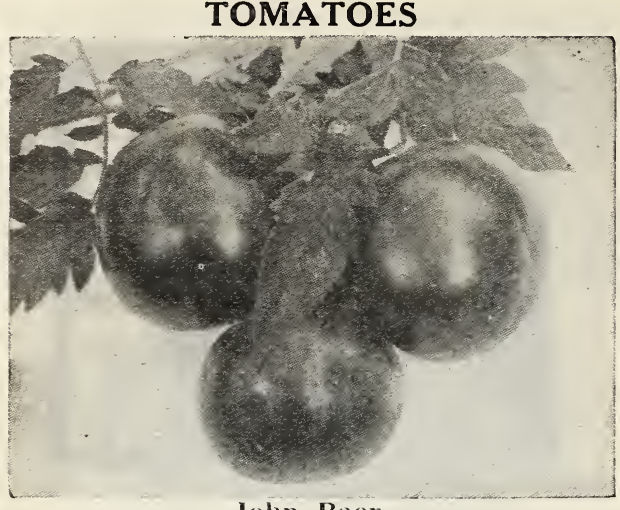

John Baer

Culture-For early use, sow one-eighth of an inch deep in January or February in a hotbed, or, if only a few plants are wanted, sow in a window box. In order to get the plants strong and stocky, they should be transplanted when two or three inches high. When all danger of frost has passed, set out in the open ground in rows, three feet apart. For later crops, sow in open ground, as above directed. An ounce will make about 1,000 plants; four to five ounces will make plants enough for an acre.

Earliana-90 days. Very early. Habit of vine dwarf and compact. Fruit borne in clusters of from 10 to 15 in a bunch. A remarkable variety and one which is in good favor with market gardeners. Pkt., 5c; oz., 35c; 1/4 lb., \$1.00; lb., \$3.00.

John Baer-An early variety, maturing with Bonny Best, producing fruit equally as good as Chalk's Jewel. Color, bright scarlet; good size and smooth. The seed we offer was grown from the introducer's stock. Pkt., 5c; oz., 30c; $1 / 4$ lb., \$1.00; lb., \$3.00.

McGee-Well known in this state on account of its heavy-bearing qualities. It will yield splendid crops when all other varieties fail. Bright crimson, solid and good flavor. Pkt., 5̃c; Oz., 40c; 1/4 lb., \$1.20; lb., \$3.50.

Dwarf Champion-100 days. A dwarf variety, sometimes called the tree tomato on account of its upright growth and its ability to stand alone without trellising. Fruit medium-sized, smooth, uniform and of a purplish-carmine color. Pkt., 5c; oz., 40c; 1/4 lb., \$1.25; lb., S4.00.

Dwarf Stone. Claimed to be the largest dwarf tomato known, almost double the size of Dwarf Champion, and is similar in habits of growth; very popular with market gardeners and home canners. Pkt., 10c; oz., 40c; 14 lb., $\$ 1.25 ; 1 b ., \$ 4.00$.

Norton-A main-crop, scarlet-fruited variety. Very similar to Stone, of which it is a selection. Introduce? by the U. S. Dept. of Agriculture for wilt resistance. Fruits are of medium size, smooth, and solid. Norton bears well and gives a good crop. Vines make a medium to heavy growth. One of the best long distance shippers. Pkt., 5c; oz., 35c; 1/4 lb., \$1.00; lb., \$3.00.

Avon Early Tomato-This is a scarlet fruited variety of the very earliest class. It bears as quickly as Earliana, produces fruits of good size, round or slightly flattened, smooth and free from cracks and of fine quality. It is very productive and its season is longer than other first earliest. Pkt., 10c; oz., 50c; 1/4 lb., \$1.50; lb., \$4.50.
Gulf State Market Tomato-This globeshaped purplish-pink tomato was developed from Early Detroit and is as early as that variety. It is said to be especially adapted to the Gulf States and California. The fruits are large, showing little depression around the stem, and free from cracks. Pkt., 10c; oz., 60c; $1 / 4$ lb., \$1.60; lb., \$5.00.

Chalk's Early Jewel-95 days. A wonderful new variety in that it is early and bears continuously throughout the season. The fruit is large, smooth, uniform and well ripened clear to the stem, and the flavor and quality are especially fine. Color bright scarlet. Pkt., 5c; oz., 30c; 1/4 lb., 90c; lb., \$2.50.

Early Detroit-A new tomato of merit; fruit smooth, uniform, nearly globe-shaped, firm and of fine quality; color purplish-pink, season early. ' Is a fine shipping variety. Pkt., 5c; oz., 40c; 1/4 lb., \$1.20; lb., \$3.50.

June Pink-95 days. A very early and productive pink form of Earliana. The best early pink on the market. Fruit solid and borne in profusion. Pkt., 5c; oz., 45c; 1/4 lb., \$1.25; 1b., \$3.75.

Beauty (Livingston's)-A second-early large, smooth purple-fruited sort of good quality. Pkt., 5c; oz., 35c; 1/4 lb., \$1.00; lb., \$3.00.

Early Acme-The plants are of strong and vigorous growth; very productive fruit of medium size, perfect form, round, slightly depressed at the ends, very smooth (never rough); color a glossy red, with purplish tinge; ripens all over and through at the same time. Pkt., 5c; oz., 30c; 1/4 1b., 90c; lb., \$2.50.

Stone-115 days. The best main-crop tomato for all purposes, and largely used for canning. Vine tall and prolific. Fruit smooth, large and uniform. Color bright scarlet. Pkt., 5c; oz., 25c; 1/4 lb., 75c; lb., \$2.25.

Yellow Plum-95 days. A small-fruited, bright golden yellow variety, very attractive; for salads or preserves. Pkt., 5c; oz., 50c; 1/4 lb., \$1.50.

Yellow Pear-Same as Yellow Plum, except that it is the shape of a pear and a trifle smaller. Pkt., 5c; oz., 50c; 1/4 lb., \$1.50.

Cooper's Special-An improved strain of Livingston's Globe. Fruit purple, globe shaped. It yields heavier than Globe and its carrying qualities are equally as good. Pkt., 10c; oz., 65c; 1/4 lb., \$2.00; lb., \$6.00.

Livingston's Globe-A large purple-fruited variety of excellent quality. Fruit large, very smooth and matures earlier than most main crop sorts. The average tomato is very deep, almost globe-shaped, and very solid. It is one of the leading varieties grown throughout Florida to ship North. Our stock of this important variety is of excellent quality. Pkt., 5c; oz., 45c; 1/4 lb., \$1.25; lb., \$3.50.

Marglobe-Tested repeatedly and approved by the United States Department of Agriculture. Is sure to be planted extensively before long. This is what the Department says about it, "Very productive, second early variety. Fruits large, smooth, meaty, red, globular. Highly resistant to wilt and somewhat resistant to blights." Pkt., 10c; oz., 75c; 1/4 lb., \$2.25; 1b., \$6.50. 


\section{ANDERSON EGG BOXES FOR SHIPPING}

Made of extra heavy cor rugated cardboard; built so as to stand rough handling and carry your setting eggs safely.

15 egg size ...................30c each Weight $1 \frac{1}{2}$ Lbs.

15 egg size..........\$3.00 doz. Weight 15 Lbs.

30 egg size, weight $21 / 2$ lbs

30 egg size, weight 26 lbs.

50 egg size, weight $31 / 2$ lbs.
50 egg size, weiglit 39 lbs.

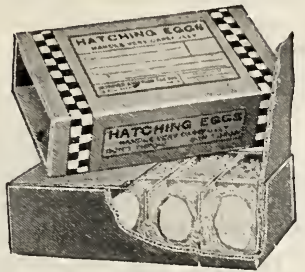

$45 \mathrm{c}$ each $\$ 4.50 \mathrm{doz}$. $55 \mathrm{c}$ each

ROYAL CHICK BOXES

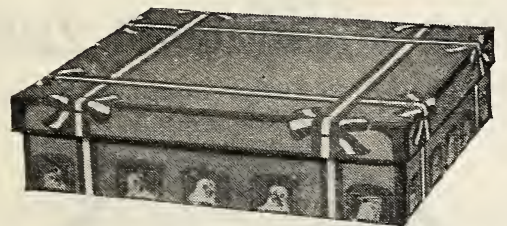

During the last few years the day-old chicks business has grown wonderfully. Much of the success of the under taking depends upon the condition in which the chicks reach their destination. Our shipping boxes are well made of corrugated board. They are strong enough to prevent crushing, light to reduce express cliarges, perfect insulation to afford protection against heat and cold

25 chick, weight $1 \mathrm{lb}$, , each

$+15$

$\ldots+\cdots$

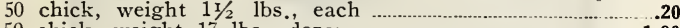

50 chick, weight 17 lbs., doze11 1.80

100 chick, weight $2 \frac{1}{2}$ lbs., each - - - - - - - - - - - - - - - - - - - 1.25

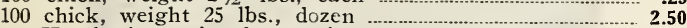

Hatcheries write for special quantity price.

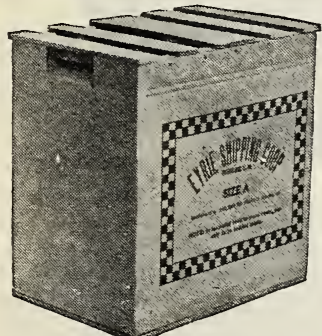

EYRIE SHIPPING

\section{COOP}

Light in weight, but strong and durable. Eids and sides heavy corrugated cardboard. Top and bottom wood. No. C, $21 \times 18 \times 22$ inches deep, each $\$ 1.00$

\section{OAKES “ECONOMY” HOVER LAMP-HEATED}

Simple in construction, made of steel throughout and durable. Can be lifted by its two hand les without disturbing the lamp les without disturbing the lamp and used anywhere with perfect safety as it stands on a leve floor; no platfcrm or other prepa ration necessary. Only a small flame is required, as the lamp is inside and no heat is lost of outing flannel.

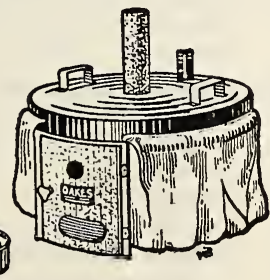

No. F-102-18-inch drum without cage

$\$ \$ .50$

\section{OAKES NEW AND IMPROVED ELECTRIC BROODERS}

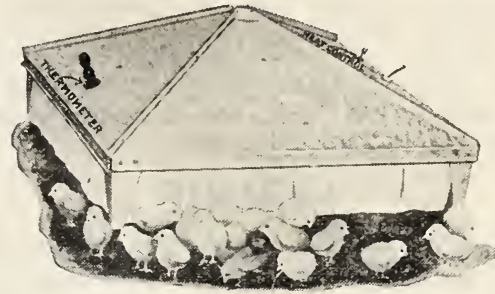

The canopy and legs are made of high quality galvanized steel of four pieces bolted and spot-welded together. The 32 inch canopy will support the weight of an average sized man.

Top is lined with asbestos and has Celotex deck above the heating element to retain the heat, in the 32 and 42 inch sizes. In addition to the Celotex insulation there is a metal heat deflector which distributes the heat.

Ventilation is provided through a series of draft chutes located above the heating clement.

Each brooder is equipped with special wafer thermostat and electric cut-off switch which provides automatic regula tion of the heat at all times.

Special thermometer, eight feet of drop cord, curtains, and pilot light furnished as regular equipment with all brooders.

No. F 90 22" Brooder complete

$\$ 12.00$

No. F 9132 " Brooder complete

16.00

No. F $9242^{\prime \prime}$ Brooder complete

20.00

Furnished in 100,300 and 600 Chick sizes.

Antomatic Heat Control. No attention required.

\section{RELIABLE BABY GRAND INCUBATOR}

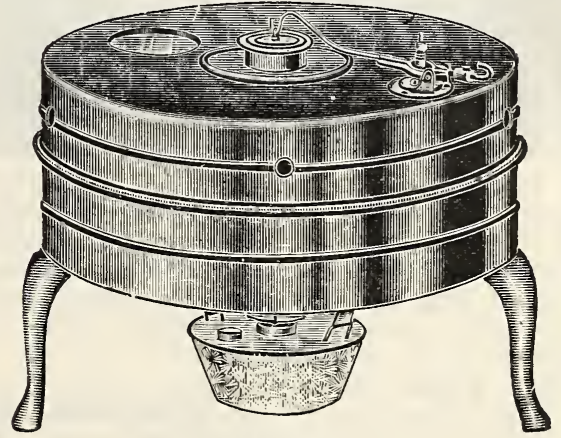

50-Egg Hot Air

It is doubled-walled with a circulation of warm air be tween walls, windows in top to see therometer without open ing machine. It is self-regulating and a positive success. Can be shipped by parcel-post, express or freight packed all in a carton ready to operate. Price $\$ \mathbf{7} .50$.

Capacity, 50 chicks. Weight 18 pounds.

\section{FREE BOOKLETS}

SLPERIOR POULTRY BOOK SLPERIOR DAIRY BOOK CONKEY POULTRY BOOK LEGEAR'S POULTRY BOOK LEE'S POULTRY BOOK POLK-MILLER DOG BOOK COMMON-SENSE vs. WORMIS
Phamplets covering all other items such as Insecticides, Poultryware, Sem es a n, B-K, Sterilac, Etc., furnished FREE for the asking. Just write us which items you desire booklet on and same will be forwarded. 


\section{RUTABAGA}

American Purple Top or Long Island-One of the best and most popular varieties, with yellow flesh. It is yellow below ground, with purple top above, and the leaves are small. A good stock-feeder or table variety. Pkt., 5c; oz., 10c; $1 / 4$ lb., 20c; lb., 60c.

\section{TURNIP}

Culture-For early Turnips, sow as soon as the ground opens in spring. Rutabagas should be sown from any time in July to first of August; but the other kinds, for winter use, may be sown from the middle of July to the end of August. Turnips are generally sown broadcast, but much larger crops are obtained (particularly of the Rutabagas) by cultivating in drills 18 inches apart, and thinning to 6 inches in the drill. Sow in drills, one pound to the acre; broadcast, 2 to 3 pounds to the acre.

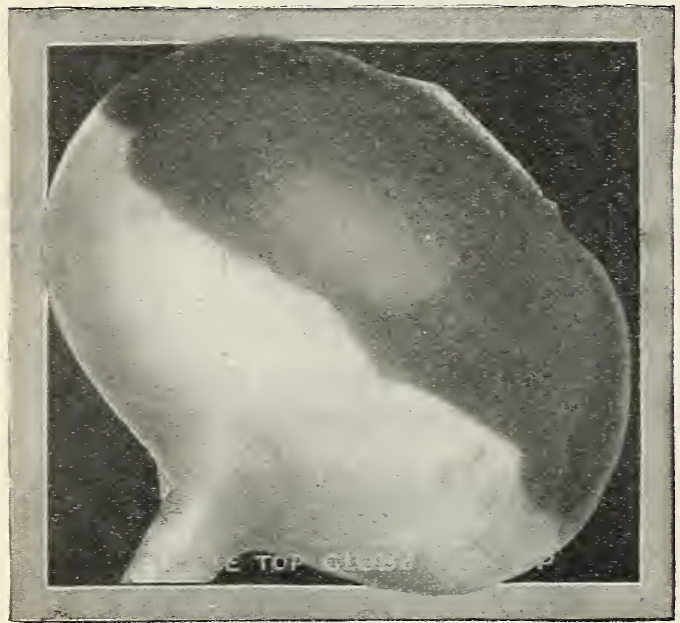

Purple Top White Globe-An early, mediumsized, globular shaped turnip of good quality for either table or stock. A heavy producer and good keeper. The flesh is white, and of good eating quality while young. Pkt., 5c; oz., 10c; 1/4 lb., 20c; 1b., 60c.

White Egg-A sort forming root the shape and size of egg in an incredibly short period after sowing. Flesh always palatable. Pkt., 5c; oz., 10c; 1/4 lb., 20c; 1b., 60c.

Pomeranian White Globe-Large white variety, used largely for stock. Is globe shaped, large leaves, hardy. Pkt., 5c; oz., 10c; 1/4 lb., $20 \mathrm{c} ; 1 \mathrm{~b} ., 60 \mathrm{c}$.

Extra Early Purple-Top Milan-An excellent medium size turnip, almost as early as White Milan, smooth white surface, purple top, flat shape, white flesh-its growth is very uniform and quality the best. Pkt., 10c; oz., 20c; 1/4 lb., 40c; 1b., \$1.25.

Cowhorn Turnip-This turnip grows very long, often 12 inches or more, and 2 inches in diameter and nearly half above ground. It is very popular for stock feeding, and is clear white except a little shade of green at the top. Pkt., 5c; oz., 10c; 1/t lb., 20c; 1b., 60c.
Yellow Aberdeen-A large sized, round, late maturing, long keeping, yellow fleshed turnip. It is hardy, productive, and valuable for stock feeding. The roots are yellow with purple top. The flesh is pale yellow, firm, tender and sweet. Pkt., כ̌c; oz., 10c; 1/4 1b., 20c; lb., 60c.

Early White Flat Dutch-Strap Leaved. A medium-sized flat variety, clear white, early and of fine flavor. A fine table variety. Pkt., sc; oz., 10c; 1/1 1b., 20c; 1b., 60c.

Purple Top Flat Dutch-Strap Leaved. An early flat variety. White with purple top. It matures quickly and has fine grained flesh of fine flavor. It forms early a fine root, even in shape and of the best quality. Pkt., 5c; oz., 10c; 1/4 lb., 20c; 1b., 60c.

\section{SATEX MAMMOTH ZINNIA}

Don't Fail to Order Some of These Wonderful Zinnias

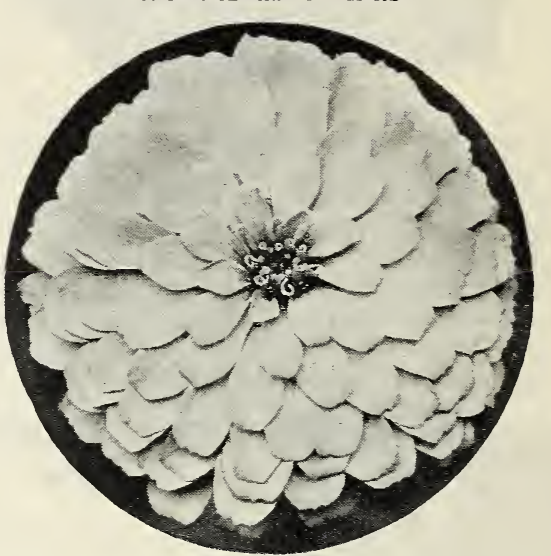

You may have often passed by a bed of mammoth Zinnias, and if you will ask the owner where he procured the seed of same, he will invariably answer that he procured them from us. Our strain of Mammoth Zinnias are known all over the State, and you cannot procure seed anywhere which will give you a better strain than our mammoth variety. This strain produces flowers as large as the finest Dahlias, magnificent in petalage and of the brightest imaginable coloring.

Double Lavender ....................Pkt., 10c; oz., 75c. Double Pink ....................................... 10c; oz., 75c. Double White ...........................Pkt., 10c; oz., 75c. Double Red ................................... 10c; 0z., 75c. Double Yellow .........................Pkt., 10c; oz., 75c. Double Scarlet ............................ 10c; oz., 75c. Double Mixed Giant ..................Pkt., 10c; oz., 75c.

Giant Dahlia Flowered Zinnia-Latest development in Zinnias with flowers of enormous size and resembling the decorative Dahlia very much in shape. Mixed colors. Pkt., 20c; 1/4 oz., 75c.

Giant Picotee Type-A remarkable new and distinct class with beautiful double flowers, each petal being distinctly tipped with various shades, resembling the Picotee Carnations. Pkt., 20c; 1/4 0z., 75c.

Write for ounce or pound prices on Flower Seeds. 


\section{BUCKEYE INCUBATORS AND BROODERS}

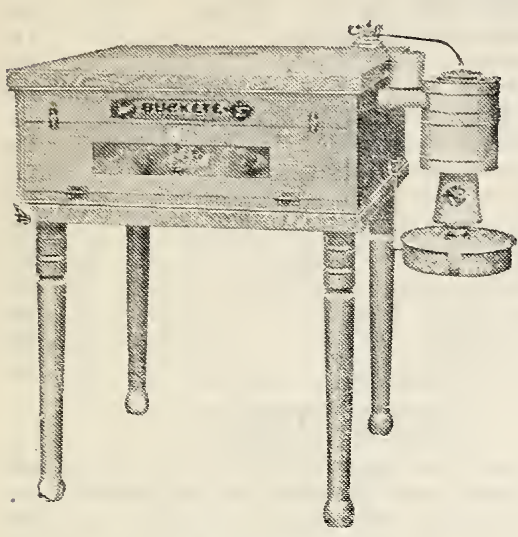

Buckeye "Standard" No. 3

Buckeye Incubators are the result of orer thirty-five years of stud and experiment. There are no other incubators like them. Buckeye "Standard" Incubators are made with double-thick case. Heat insulation is practically perfect. The hot water circulating tank is of pure copper-it will never rust or corrode. The automatic regulator assures uniform temperature at all times without any attention whaterer. The lamp is supplied with either an oil or gas burner-each one efficient, economical are a little more simply constructed and a little less expensive in pricebut they contain all the essential features of Buckeye design.

Note this: Both Buckeye "Standard" and Buckeye "Style E" Incubators carry the same unlimited guarantee - to hatch every hatchable egg every time and under all conditions. You can select either type of Buckeye Incubator and be sure of the best possible hatching results.

\section{Capacities and Weights}

"Standard"

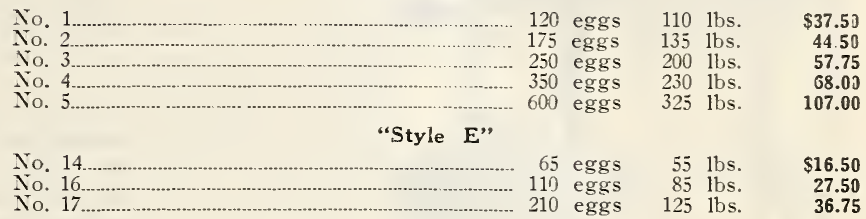

\section{BUCKEYE “COLONY" BROODERS RAISE EVERY RAISABLE CHICK}

The Buckeye Oil-Burning Brooder has the new improved Burner that gives the maxinum amount of heat with the minimum consumption of oil. It is a wick burner and the oil is fed by gravity. Buckeye is self-feeding and selfregulating; it doesn't clog; it doesn't flare up; it doesn't go out. Can be safely operated on any floor. Has "Diafram" Heat Conveyor, so attached to the canopy that it insures the radiation of heat to the very outside of the brooding area.

\begin{tabular}{|c|c|c|c|c|}
\hline No. $27 \cdot \mathrm{A}$ & $\begin{array}{l}\text { Capacity. } \\
\text {.200 chicks }\end{array}$ & $\begin{array}{l}\text { Canopy. } \\
\text { 34-inch. }\end{array}$ & $\begin{array}{l}\text { weight. } \\
40 \text { lbs. }\end{array}$ & $\begin{array}{l}\text { price. } \\
\$ 17.50\end{array}$ \\
\hline No. $80 \ldots$ & ...350 chicks & 42-inch. & 50 lbs. & 19.00 \\
\hline No. 81 . & ...500 chicks & 52-inch. & 60 lbs. & 21.5] \\
\hline
\end{tabular}
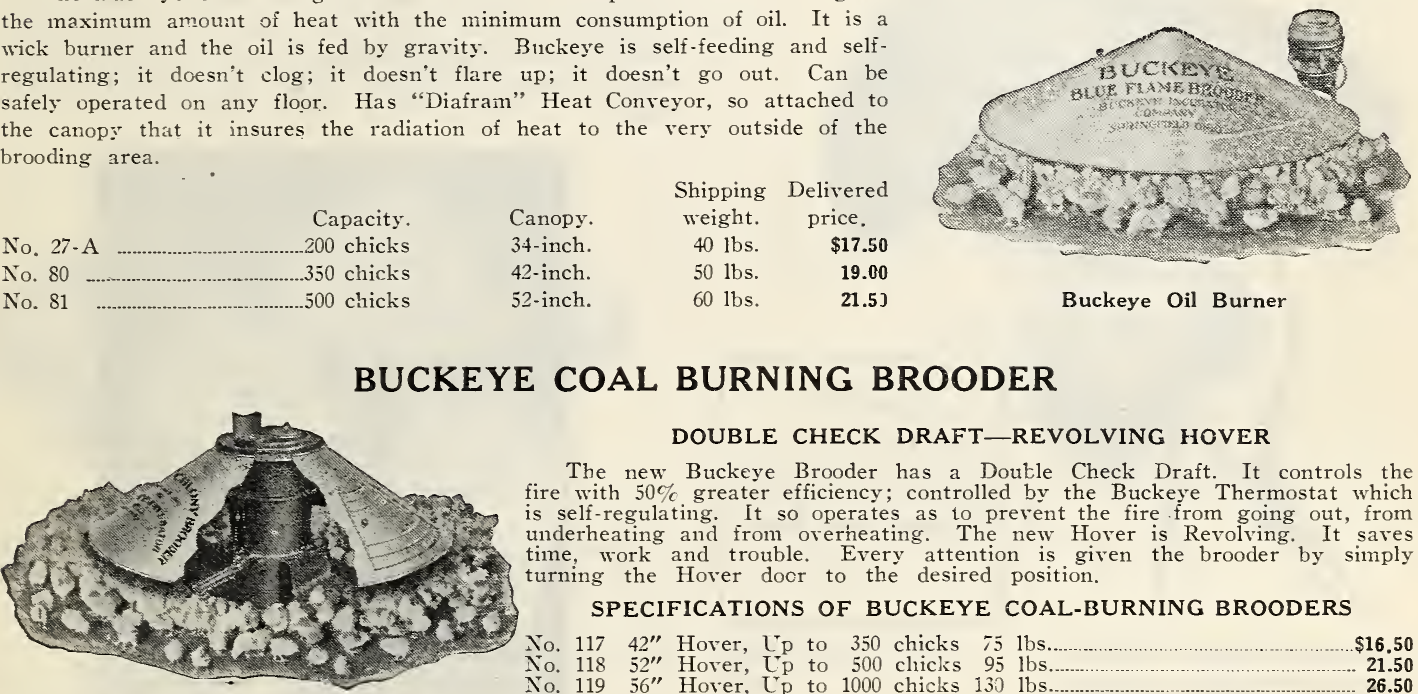

\section{DOUBLE CHECK DRAFT-REVOLVING HOVER}

The new Buckeye Brooder has a Doukle Check Draft. It controls the fire with 50\% greater efficiency; controlled by the Buckeye Thermostat which is self-regulating. It so operates as to prevent the fire from going out, from underheating and from overheating. The new Hover is Revolving. It saves time, work and trouble. Every attention is given the brooder by simply turning the Hover door to the desired position.

SPECIFICATIONS OF BUCKEYE COAL-BURNING BROODERS

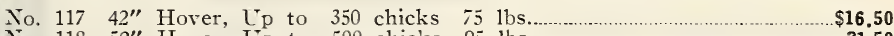

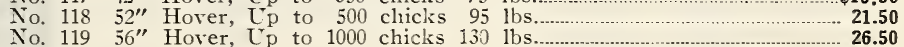

\section{BUCKEYE ELECTRIC BROODER}

After four years' experimental and development work the Buckeye Electric Brooder has been perfected. Poultrymen can now secure a brooder heated by electricity that will give them maximum of brooding satisfaction without the disadvantages that have heretofore been

common with brooders of the electric type.
Buckeye Electric Switches are dependable. The heating elements are sturdily constructed, built to last and automatically controlled and are designed for 100 to 125-volt current.

Buckeye Electric Brooders are made in four sizes, with capacities of $50,100,200$ and 300 chicks respectively. These brooders will acutally take care of this quantity of chicks. Do not be fooled by large ratings of competitive brooders. With electric brooders it is necessary to use a curtain as shown in the illustration. If you compare the diameter of Buckeye camopies and compare the the brooders and their chick rating, the accuracy of Buckeye rating is easily determined.

Chick capacity

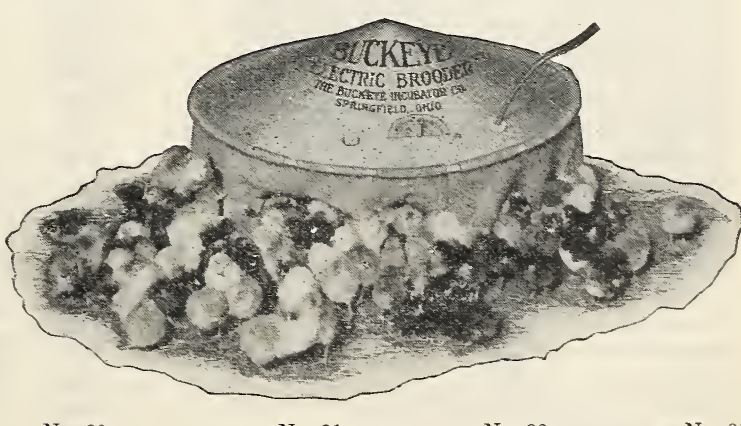

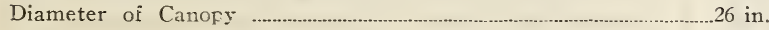

Price 


\section{HIGH GRADE FLOWER SEED}

Aster-Queen of the Market..........................10c

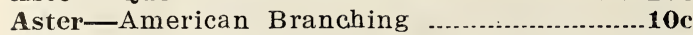

Aster-Globe Quilled ...................................10c

Bachelor's Buttcn-Mixed ............................10c

Balsam-Camelia, Fine Mixed ......................10c

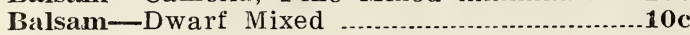

California Poppy .................................................

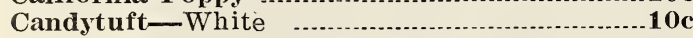

Candytuft_Fine Mixed ................................10c

Carnation-Marguerite, Fine Mixed..............10c

Castor Bean-Mixed ....................................10c

Cockscomb-Dwarf Mixed ............................10c

Chinese Wool Flower..................................10c

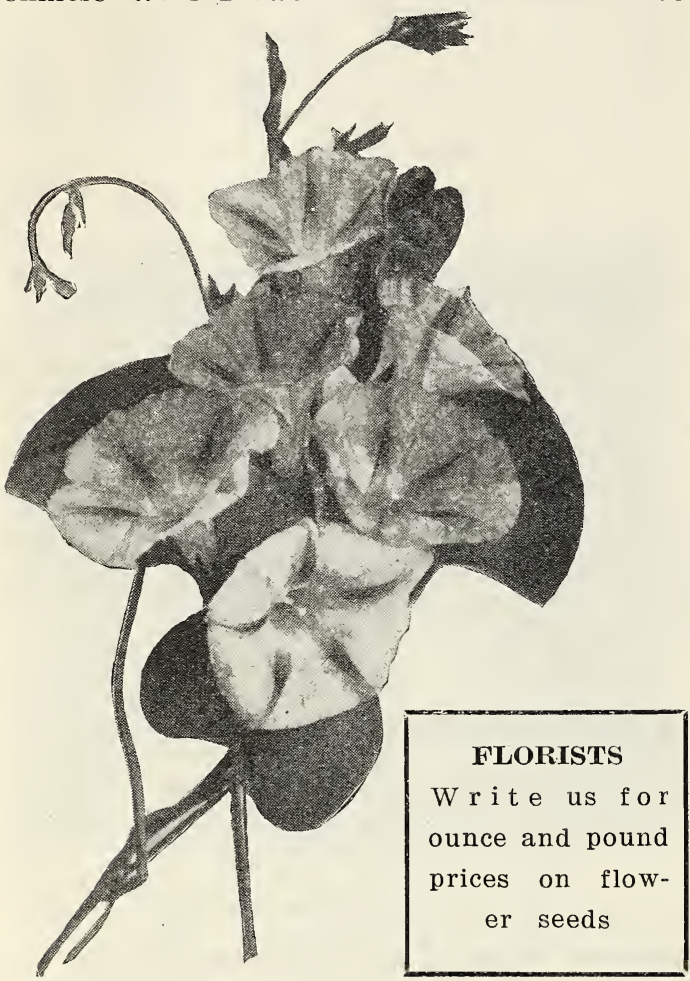

Chrysanthemum-White ................................

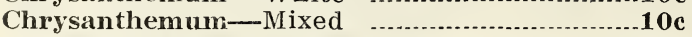

Chrysanthemum-Yellow ..........................10c

Cosmos-Giant Mixed ........................................

Cypress Vine-Mixed ...................................10c

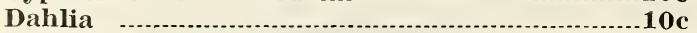

Forget-Me-Not-Alpestries ..........................

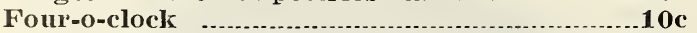

Globe Amar'anth ................. 10c

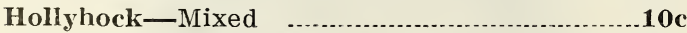

Hyacinth Bean-White ................................10c

Hyacinth Bean-Purple ....................................

Hyacinth Bean-Mixed.................................... 10c

Morning Glory—Sky Blue ..........................10c

Morning Glory-Japanese Mixed...................10c

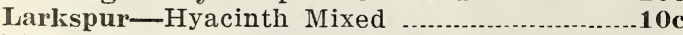

Marigold-Prince of Orange...........................10c

Mignonette-Machet ....................................10c

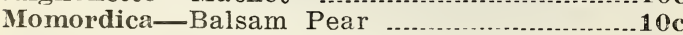

Momordica_Balsam Apple ...............................

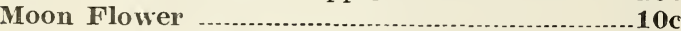

Nasturtium-Dwarf Mixed ............................10c

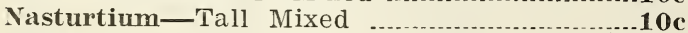

Pansy-Non Plus Ultra .......................................
Pansy-Trimardeu Mixed ..................................

Petunia-Mixed ...............................................

Phlox Drummondi-Choice Mixed ...................10c

Pinks-Double China Mixed..........................10c

Pinks-Double Japan Mixed ...........................10c

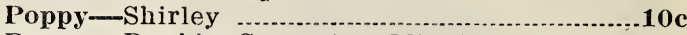

Poppy-Double Carnation Mixed .......................

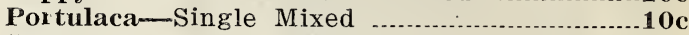

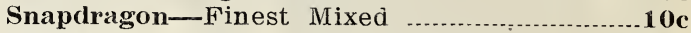

Salvia-Splendens ..........................................

Stock-German Ten Weeks, Mixed................10c

Sweet William-Fine Mixed .........................10c

Sweet William-Double Mixed .......................10c

Verbena-Hybrida Mixed .............................15c

Vinca-Periwinkle, White ...................................

Vinca-Periwinkle, Rose ............................10c

\section{SWEET PEAS}

Sweet Peas-Spencer Variety (Mixed) Sweet Peas will grow and blossom in any good garden soil. For best success sow early, as early as the ground can be worked in the spring. Regardless of the weather sow early, in trenches 4 inches deep; cover about 1 inch with soil, and fill the trench as plants grow. Set the support early and hoe often. The Spencer mixture which we offer contains a beautiful mixture of colors and of large, gracefully frilled blossoms.

Superb Spencer Mixed. Pkt., 10c; oz., 30c; lb., $\$ 2.50$.

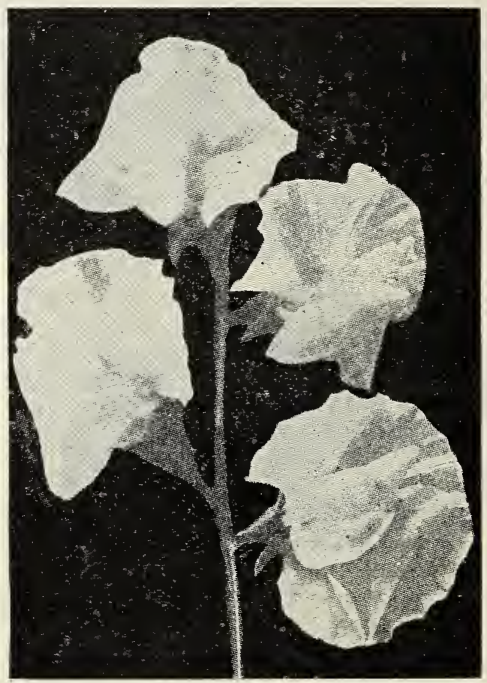

SWEET PEAS

\section{TUBEROSES}

Mexican Everblooming-The most beautiful Tuberose that was ever brought to our attention. It begins to produce its fragrant flowers in June and blooms continually until frost. Plant them in good soil and water them occasionally during extreme warm weather, and an abundance of lovely flowers will be the reward. In the southern part of the state the bulbs may be left in the ground all winter. Doz., 40c; 100, $\$ 2.00$.

Inoculate Sweet Peas with Farmogerm 


\section{Lectrohatch}

\section{ELECTRIC INCUBATORS AND BROODERS}

"DO IT ELECTRICALLY!" Lectro-hatch incubators and brooders liave made poultry raising safe, easy and certain. Chicks hatched by electricity have the appearance of being a week old the day they're hatched. Even heat and fresh, pure air gives the chick every advantage for life, growth and development that Nature intended.

The Lectro-hatch Brooder has the same principle of realiable heat and automatic temperature control as the Lectro-hatch Incubator. Night or day the temperature in your brooder never varies. There are no ups or downs-no frozen or roasted chicks. Chicks breathe free, pure air all the time. Pure air, unchanging heat and no crowding will prevent a big part of your usual chick losses. Lectro-hatch Brooders are strongly built of heavy galvanized metal, with heavy feit curtain-sturdy, attractive, effic.

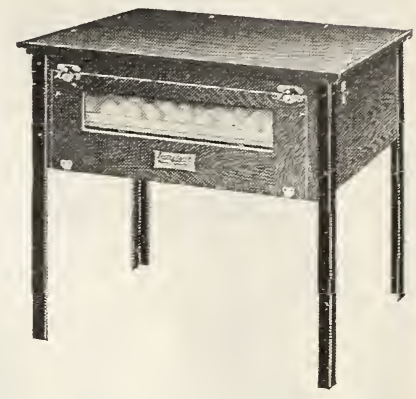
ient, and durable.

When ordering Lectro-hatch incubators or brooders, state voltage of your electric current.

\section{MADE IN TWO POPULAR SIZES}

\section{0-Chick and 500 Chick}

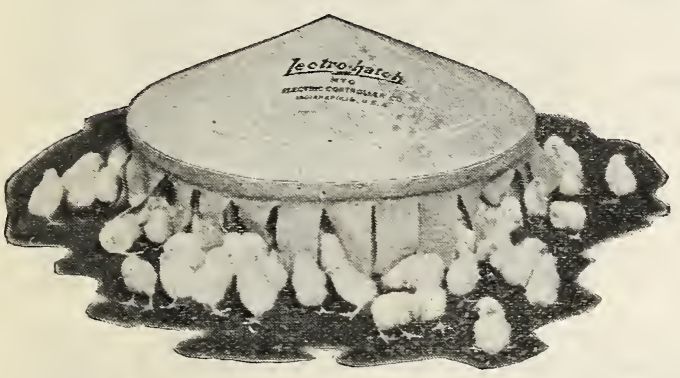

It's all Brooder-No lamp, No Stove!
Lectro-hatch

ELECTRIC INCUBATORS

65 egg size....................................... 23.50

150 egg size...................................... 38.00

300 egg size......................................... 67.00

600 egg size......................................... 118.00

\section{lectrohatch}

\section{ELECTRIC BROODERS}

150 chick sizo ( 28 inch diameter)

500 chick size......................
$\$ 18.00$

23.50

\section{AUTOMATIC INCUBATORS}

\section{ALTOMATIC STANDARD INCUBATORS}

\begin{tabular}{|c|c|c|c|c|}
\hline & 1. $-125-\mathrm{egg}$ & Automatic & $\ldots$ & 39.5 \\
\hline & 2.-175-egg & Automatic & . & 44.5 \\
\hline No. & $3 .-250$-egg & Automatic & - & 57.7 \\
\hline No. & 4.-3 75 -egg & Automatic & & 73.0 \\
\hline No. & $5 .-500$-egg & Automatic & & 98.0 \\
\hline
\end{tabular}

\section{AUTOMATIC MAMNOTH JUNOR PORTABLES}

No. 5D.-500-egg. Two hatching cabinets of 250 eggs each …........................... \$111.5

No. 7.750-egg. Two hatching cabinets of 375 eggs each ..................................... 150.00

No. 10.-1000-egg. Two hatching cabinets of 500 eggs each ....................................

\section{DELAWARE AUTUNATIC}

No. 65.- 65 -egg

No. $160 .-160$-egg

No. $220 .-220$-egg
Delaware

Delaware

Delaware
Automatic.

Automatic.

Automatic.
18.00

32.50 36.75

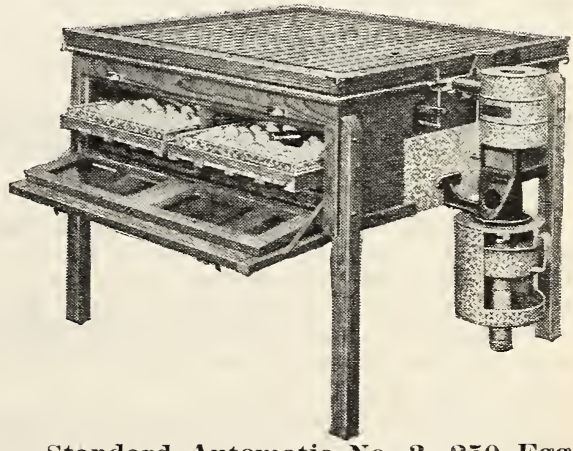

Standard Automatic No. 3, 250 Egg Size 48x35 inches

WRITE FOR FREE COPY OF FULL DESCRIPTIVE CATALOG 


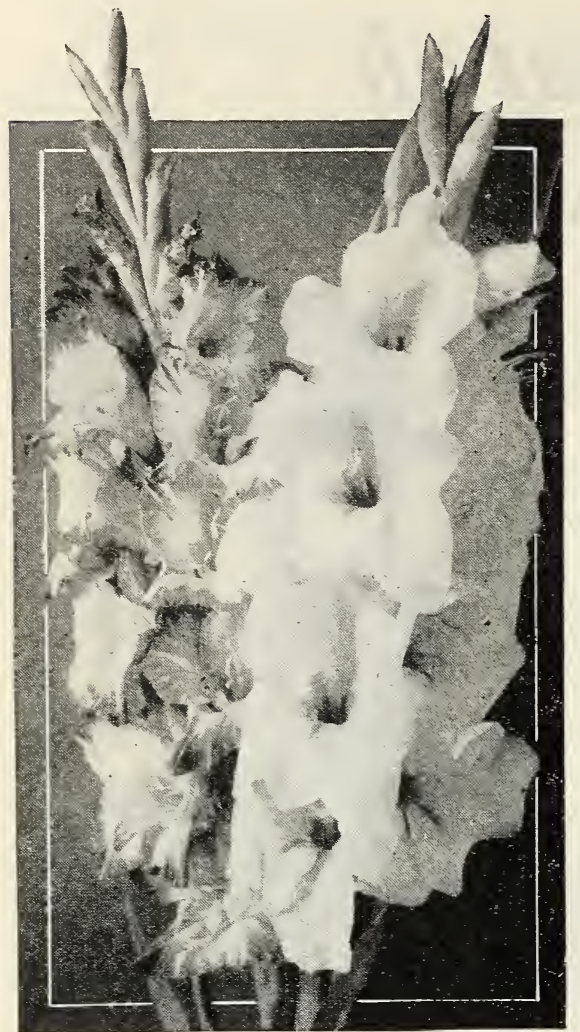

\section{QUEEN'S WREATH}

Antigonon Leptopus-(Rosa $M$ o n t a $n$ a, Mountain Rose or Queen's Wreath.) A lovely flowering vine, bearing most profusely immense racemes of beautiful rose colored flowers. Hardy along the coast, but inland it is liable to be killed down by frost but will come away from the ground again the next spring and quickly attain considerable height. Each 35c and 60c.

\section{GLADIOLI}

These are the most attractive of all summer flowering bulbs succeeding in any position. They grow in the most luxuriant manner in the South, and should be in every garden. We have made our price very low so as to place them in reach of the most modest buyer. Plant in open ground when danger of frost is past. Plant eight inches apart and cover about three inches deep.

America-One of the most popular Gladioli offered; lavender pink flowers of very large size, borne on robust stems, make delicate cut flowers. Doz., 50c.

Mrs. Frank Pendleton-A very early variety. The flowers are of a beautiful salmon-pink with a creamy white blotch in the throat which greatly enhances its beauty. Doz. $\mathbf{7 5 c}$.

Halley-A most attractive early-blooming sort, with large well-opened flowers of delicate salmon-pink with a creamy blotch on lower petals. Per doz. 75c.

Peace-One of the grandest white introductions of 1912. This variety seems to produce blossoms later in the season than any other variety. Dozen $\mathbf{7 5}$ c.

Mrs. Frances King-The magnificent flowers measure four and a one-half inches across. A brilliant flamingo-pink, blazed with vermillion red. Doz. $75 c$.

Schwaben-For size of flower and keeping qualities this Gladiolus is considered as being the best of yellows. Dozen 75c.

\section{FIELD SEEDS}

The varieties of field seed listed are adapted to the climate conditions of Southwest Texas. They are grown for us by one of the best growers of field seeds in the state, and you will find them of the best quality and true to name.

No'TCE-Owing to the ract that a great many merchants sell country run seed to the trade, we are forced to put out two grades of grain sorghums, the Satex Standard brand, which is thoroughly recleaned and tested, and is put up for the trade who desire quality. If you desire the other grade, we can supply same at competitive prices. Quality Seeds pay in the long run, and we can recommend Satex Standard Brand as the highest quality.

\section{ALFALFA}

Hairy Peruvian Seed-Facts you should know. It is impossible to distinguish Hairy Peruvian from other varieties of Alfalfa seed. Plant five pounds more to the acre than other varieties, must have thick stand to give you good quality hay, otherwise stems will be very woody. Plants grow taller, stems larger with hair on full length of stem; also hair on under sides of leaves. Color of leaves grayish-green, with the veins in them showing very prominent. Lb., 35c.

\section{ALGERIA}

Claude B. Hurlbut, the originator, says: That after 7 years of careful breeding he is ready to offer to the farmers a New Grain very much superior both as a grain and as a forage crop to any of the crops now being grown.

Produces in most cases from 2 to 3 times as much grain per acre as the other grains, and as much as 12 times as much fodder per acre.

It makes a large soft grain, the largest heads ever produced by any crop. The heads weighing from $3 / 4$ to 1 pound, each making as high as 8 heads to the stool.

It makes a stalk from 4 to 5 feet, with leaves about twice the size of Indian corn, and from 15 to 19 leaves to the stalk. 1b., 20c.

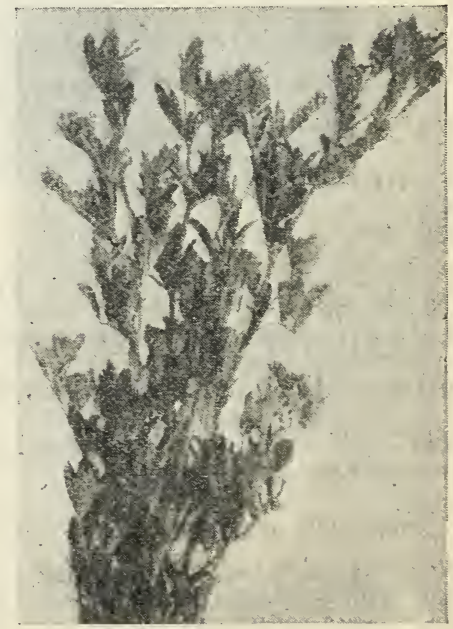




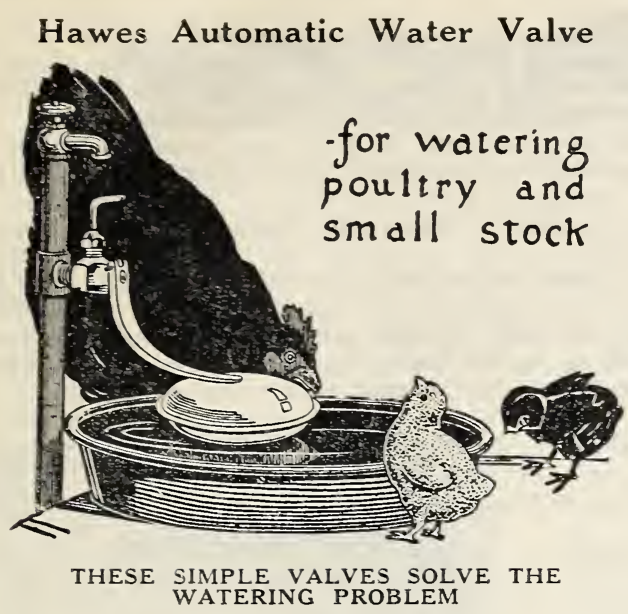

At last, a trouble-proof water valve that works automatically! It is so simple in design, so perfect in operation ycu will marvel you did not think of it yourself. Easy to attach-nothing to get out of order. A hoilow metal float rests on the surface of the water, and as level rises and falls, valve automatically closes and opens, This insures a constant supply of pure, clean, trinking water-a vital factor in successful poultry and smail stock raising.

Simplicity

Combination with individual shus:-off

\section{GRIT AND SHELL BOXES}
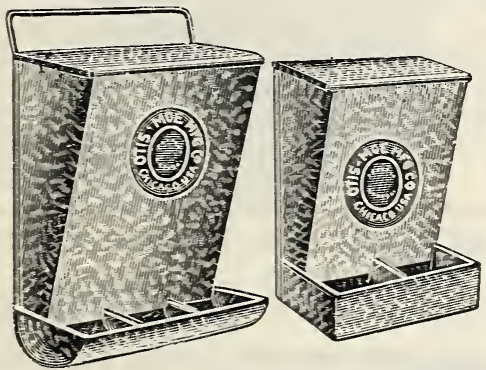

Grit, shell and charcoal have now become a recognized essential part of the diet insuring healthy fowls. They cannot be more economically supplied than in one of our inexpensive compartment boxes. Can also be used as a eed hopper for little chicks.

No. 45-For baby chicks, each Shipping Weight $1 \mathrm{Lb}$.

$\$ 0.45$

No. 9-For grown birds, each 1.10

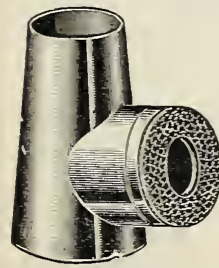

\section{MOES EGG TESTER}

Used to test fertility to eggs during ïrst week of incubation. Use on an ordinary lamp. No. 2 burner) in a dark room. It will illuminate inferior if egg so that you will know if the chick is alive. Also shows size of aircell. Each 25c.

Shipping Weight $1 \mathrm{Lb}$.

\section{MOES POULTRY PUNCH}

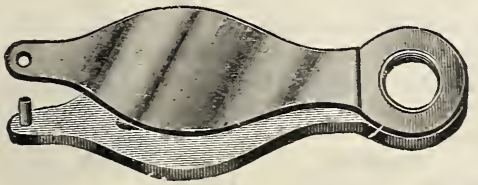

A popular and practical punch. Nakes a clean perforation and does not bruise the foot. No. 38 Moe's Punch. foration and does not bruise the foot. No. 38 Moe's Punch.

\section{MOES ALUMINUM LEG BANDS MOE'S LEG BAND 29412}

Made of sheet aluminum with large raised numbers, eas to read from a distance. Adiustable for any size fow 1 Numbered 1 to 4999 , as wanted.

12 bands

50 bands

$\$ .15 \quad 100$ bands

$.25 \quad=00$ lind

$\$ .70$

\section{BANDETTES}

Bandettes are easily applied singlehanded: simply open out Bandette, hook the bird's leg; should not fit tight.

Bandettes are made in 5 colors: Blue, red, yellow, green, pink. Two sizes:

No. 9 for Leghorns, and

No. 11 for Rocks, Reds, etc.

Bandettes are sold only in unbroken sets of 25 in one color: $1-25,26-50,51-75,76-100$, and so on.
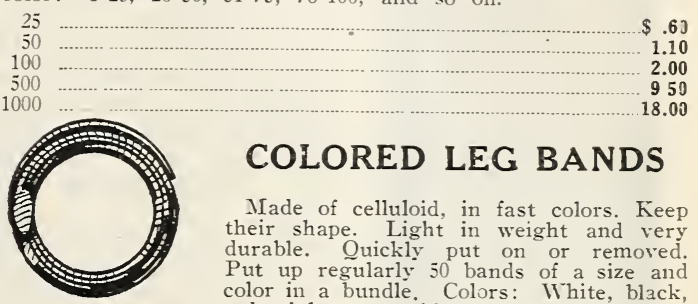

\section{COLORED LEG BANDS}

Made of celluloid, in fast colors. Keep their shape. Light in weight and very durable. Quickly put on or removed. Put up regularly 50 bands of a size and color in a bundle. Colors: White, black, red, pink, green, blue. purple and yellow.

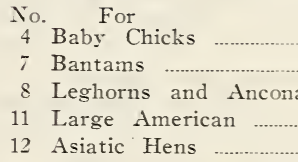

$\begin{array}{rr}50 & 100 \\ \$ .25 & \$ .40 \\ .35 & .6 \\ .35 & .6 \\ .40 & .75 \\ .45 & .80\end{array}$

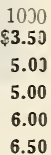

ECONOMY POULTRY BANDS
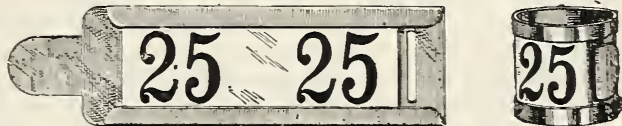

Poultry Sizes. The Standard poultry sizes with two large black numbers from 1 to 100 , with black ink on celluloid. Size No. 3 (For Leghorn Hens.) 3c each. Siz No. 4 (For Rhode Island Red, Plymouth Rock, and Orpington Females, and Leghorn Males.) One-half inch wide, two and one-half inches long from slot to shoulder. $3 \mathrm{c}$ each, 100, \$2.25. Shipping weight $8 \mathrm{oz}$

\section{ALUMINUM PIGEON BANDS}

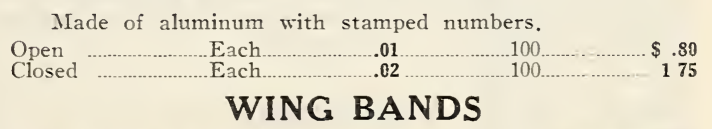
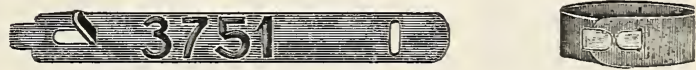

WING BANDS - Double clinch open

1c each; 75c 100

\section{MOES IDEAL POULTRY PUNCH}

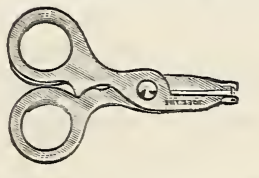

A new improved punch. Works easily, cuts clean, and does not pinch the foot. Length $3 x / 2$ in Nickel plated.

No. 39 Noe's Ideal Punch, ea. 50c

NOTE-We can get you any style leg band you desire and numbered up to 1.000 . It will take from one to two weeks to fill these special orders. $25 \%$ of amount of order required when sending in order. 


\section{SEED CORN}

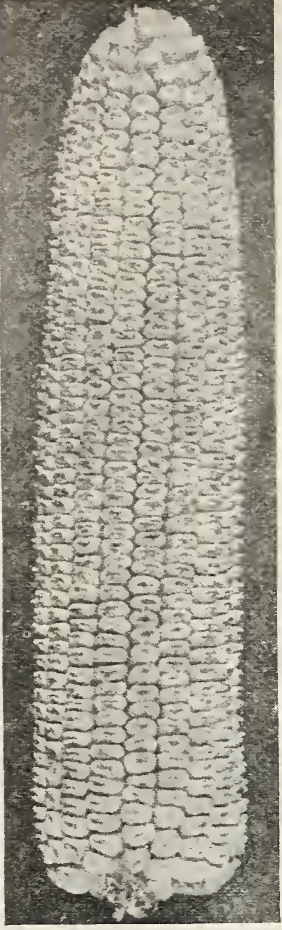

Surecropper

Giant Strawberry-We consider this to be the finest variety of corn to grow for feed. It is very productive and makes fine big ears. Firstclass seed of this variety is very scarce this year. Lb., 10c.

Hickory King-Has the smallest cob of any corn grown. Makes a very large, white, flat grain and is very largely planted for roasting ears. Lb., $10 \mathrm{c}$.

Bloody Butcher-The standard variety of large, red grain corn. Enormous yielder. Lb., 10c.

SureCropper Corn-A truly remarkable drought resisting power. As old as is the history of corn growing in the South and Southwest is the search for a corn able to hold up and make a crop on the scanty moisture which we have in so many fields at some period of almost every season. In Surecropper we have found that corn. Lb., 10c.

Giant White Red Cob-Makes a very large ear of the finest corn. Grains very large, deep, wide and thick, cob red, very popular wherever tried. We recommend this as being the finest variety of White Red Cob Corn. Has a very large, deep, wide, thick grain. Grains of medium size. Lb., $10 \mathrm{c}$.

Giant Yellow-This beautiful yellow Corn is deeply grained and very uniform in size. It is a sure cropper and good yielder. Matures in 90 to 100 days. Lb., 10c.

Native Squaw Corn-A drouth-resisting variety, plantable in the summer months. It has blue and white grains, therefore not so desirable by the market gardener. However, it makes a sweet and very juicy roasting ear. Lb., 10c.

Texas Grown June Corn-The stalks under favorable conditions grow from 7 to 8 feet high, and yields from 30 to 60 bushels to the acre. For best results it should not be planted until June or July, as it stands the hot weather better than any corn. Seed can be procured at any time after May 15th. Lb., 10c.

Champion White Pearl-An extra early pure white variety of dent corn. Matures in 100 days from time of planting, is very productive and the ears are exceedingly heavy. The grains are extra deep and white, and the cob is very small. A great favorite. Lb., 10c.

Yellow Shoepeg-An excellent long thin grained yellow variety, excellent drouth resister. matures in 90 days. An excellent variety for the dry land farmer. Lb., 10c.

Reese Drouth Resister Corn-Our original stock seed came from Reese and besides improving same we have acclimated it, being grown on Rancho Dos Hermanos, Bexar County. It is a white early maturing, deep rooted drouth resisting corn, with medium sized stalk; a corn that is easy to get a stand of, for it is a very hard variety and a fast grower. Reese Drouth Resister is an exceptionally deep rooted corn which roots almost straight down, with an abundant root system, permitting plowing within six inches of stalks and to a depth of six inches without disturbing the root system. It is almost impossible for a man to pull up a stalk of Reese Drouth Resister when in roasting ear. Lb., 15c; pk., \$1.50.

\section{POPCORN}

There is always a good market for Pop Corn, and every corn grower should plant it.

White Rice-This is the best variety of white Pop Corn for popping. 10c lb.

Jap-O-Rice-A newer variety. Cob small, grains long and slender. Used by nearly all commercial poppers. A really wonderful variety. Lb., 15c.

Queen's Golden-Produces ears in great abundance on stalks nearly six feet high. It pops perfectly white. A single kernel will expand to nearly an inch in diameter. Ib. 15c.

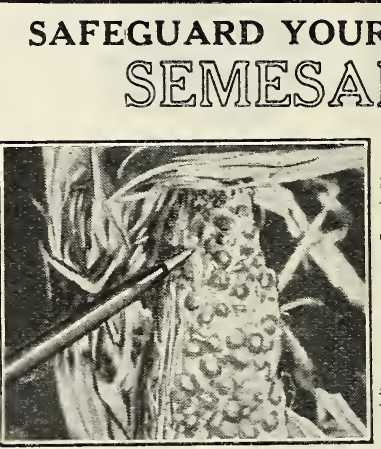

Diseased Ear of Sweet Corn

Fortunately through the disinfection of seed corn with Semesan Jr. these diseases are not only controlled but largely prevented.

A simple dusting of seed corn saves time, money and materials in planting. Three ounces of Semesan Jr. will treat one bushel of seed. A cost of only 4 cents an acre of field corn and 6 or 7 cents per acre of sweet corn. Why take chances when low cost protection is available?

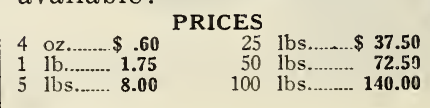

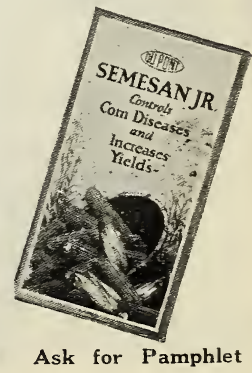




\section{COMMON SENSE vS WORMS}

"COMMON SENSE vs. WORMS" is the name of a 32-page booklet, lrimful of interesting information for poultry-folks whose chickens are backward in growth and development, have pale faces and shanks, and stand around droopy, with eyes closed. If there is a steady and comparatively high mortality in your flock; if some of your birds "go light," then die; or if they are affected with brownish diarrhoea, the cause is likely to be from intestinal worm infestation.

Other effects of worm infestation include: irregularity in egg laying, going lame, or developing "staggers," and particularly a condition of low vitality so they easily catch colds sneeze, have watery eyes, canker, roup and chicken pox.

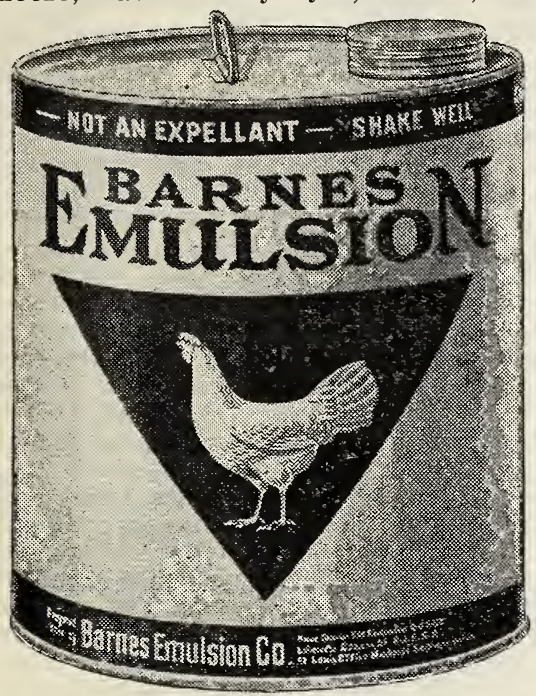

\section{TO CONTROL THE WORM EVIL}

you have your choice of EXPELLING them by dosing your birds with tobacco, nicotine and other vermifuges-OR feeding Barnes Emulsion to your birds in their water or mash. The main objection to EXPELLING the worms is that THOUSANDS of WORM EGGS are also apt to be expelled, to be picked up by the birds, causing a re-infestation more disastrous than ever, WHEREAS THE ACTION OF BARNES EMULSION IS TO AID IN SOOTHING AND HEALING THE INFLAMED INTESTINAL TRACT and build health and vitality in the fowl while at the same time preventing round worm larvae, in the intestinal tract, from developing into worms. TO PROVE THE MERIT AND WONDERFUL EFFECTIVENESS OF EMULSION TO YOUR OWN SATISFACTION, you need only to obtain a can of it and make a comparative test as explained on page 13 of the booklet.

\section{"Common Sense vs. Worms" \\ Prices: Pt. $60 \mathrm{c}$; Qt. $\$ 1.00$; Gal. $\$ 3.00$; 5-gal. Keg. $\$ 12.50$}

Delivered anywhere in the U. S. only.

\section{TFII An Ideal Disinfectant and ILIL Deodorant in Powder Form}

Sterilac is the ideal disinfectant, deodorant and sterilizing agent for dairies, creameries, poultrymen, hotels and restaurants to use. Sterilac is forty-five times stronger than carbolic acid as a germicide, yet it can be used without danger of poisoning. Sterilac is not a cleaning agent and is not to be used as such.

Sterilac is the best available deodorizer and sterilizer for milking machines, milk cans, milk bottles, separators, cooling vats, pans, earthenware and all dairy utensils. In connection with thorough cleansing it keeps the bacteria count down to the lowest point.

Poultry. It is a recognized fact by the leading poultrymen that proper sanitation is one of the most important factors to the poultry raiser. Sterilac is one of the most valuable agents for the pouitryman to use in his sanitation work. Use Sterilac to spray incubators, brooder houses, roosts, etc. Feeding pans should be scrubbed daily and disinfected by using Sterilac. Also add Sterilac to the drinking water.

Hotels and Restaurants. Sterilac is the ideal agent to use for sterilizing dishes, glasses, and eating utensils; also it may be used to dest roy foul odors.

\section{PRICES}

2 oz. bottle $\$ \mathbf{1 . 0 0}$ makes 60 gallons

8 oz. bottle $\mathbf{2 . 7 5}$ makes 240 gallons

16 oz. bottle $\mathbf{5 . 0 0}$ makes 480 gallons

5 lb. can $\mathbf{2 1 . 0 0}$

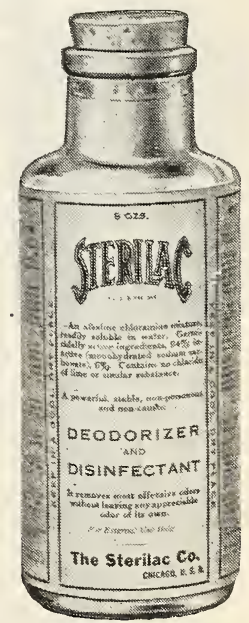




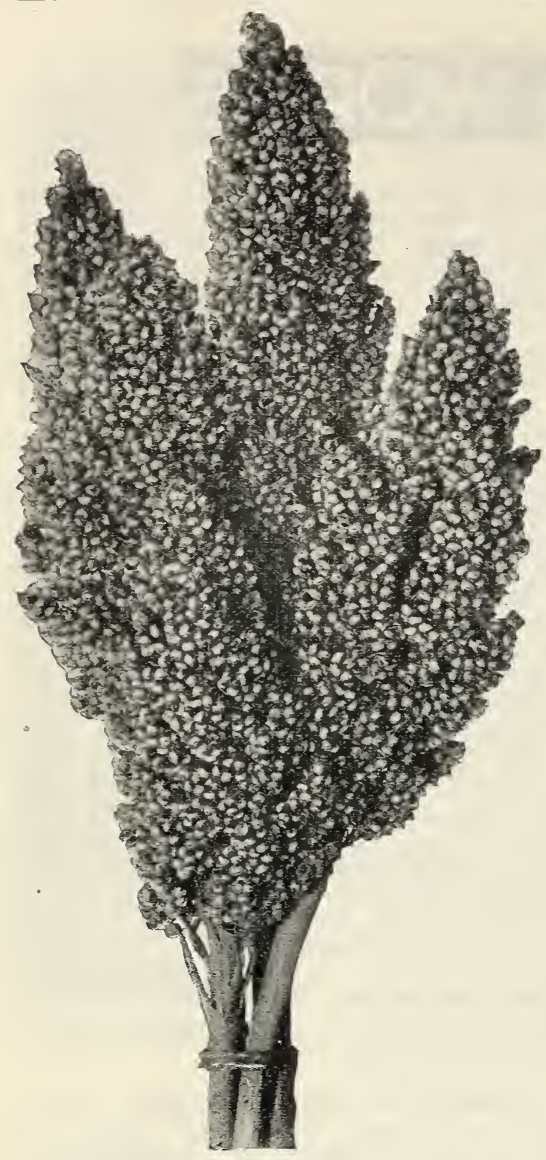

Feterita

\section{NON SACCHARINE SORGHUMS}

Dwarf Straight Neck Yellow Milo Maize-This variety is the most popular Milo Maize and stands the drought well. It is earlier than Kaffir Corn and White Milo Maize, and very prolific. Stock seems to prefer it to corn, and it has a laxative effect on them, keeping them in good condition. 1b., 10c.

Dwarf Black Hull White Kaffir-It makes a straight upright growth and has a strong stem with enormous wide leaves. The stalks keep green and are brittle, making excellent fodder, either green or dried, which is highly relished by cattle and horses. The heads form at the top of each stalk. For the grain sow in rows 3 feet apart, 3 to 5 pounds of seed to the acre. For fodder sow one-half to one bushel, either broadcast or in drills. 1b., 10c.

Feterita-The best drought-resisting nonsaccharine sorghum, and pretty well known in this state. Earlier than Kaffir Corn, and a very heavy yielder. The grain is similar to Milo, but is pure white and also larger and softer. It does not shatter badly and yields as high as So bushels to the acre. lb., 10c.

Shallu or Egyptian Wheat-This grain grows something like Broom Corn. It stools out from the root, making from three to six stalks. It has been planted in almost every section of Texas and has produced splendid crops. It is very productive, making an enormous yield of grain and fodder, and has given great satisfaction to every grower. Shallu or Egyptian Wheat should be sown in drills three feet apart, using from five to ten pounds of seed per acre. Lb., 10c.

Hegari, the New Grain Sorghum-Some years ago when Kaffir Corn, Milo Maize and Feterita were introduced into the dry-land farming crop catalog many people probably imagined that the limit in grain sorghum development had been reached; but that is almost certainly a mistake. We have abundant reason to hope for greater things yet. The new grain Sorghum Hegari, while it is too recent an introduction to justify settled conclusions, certainly promises in some respect, to out-merit ail of its predecessors. Ib., 10c.

Shrock Kaffir Sorghum-This is a comparatively new. grain which was originated in Oklahoma and has been planted in Texas for several years. It is claimed to be one of the finest of the sorghums' for torage and ensilage as it is quite sweet and grows an abundance of broad, long leaves. It is a wonderful grain to stool out, not unusual for one seed to send up six to ten stalks each making a fine head of large, light brown grains, which make an excellent stock and poultry food, one of the best drought resisters, of the sorghum family. Our seeds are acclimated. Drill at the rate of 3 to 5 pounds per acre. Price: 1b., 10c.

True Darso-This wonderful sorghum is neither sacharine nor nonsaccharine. It originated in what is called a "spor" stalk brought in by a farmer in 1912 to the Experiment Station at Stillwater, Oklahoma. After 8 years experimenting Dean Knight stated it was the best silage and feed crop, and the people of Coryell County, Texas, seem to indorse same, as they are rather enthusiastic about it. - Darso does best on heavy loams or black land, but also does well on sandy soil. For feeding purposes, it is probably the best grain-fodder, and silage crop for this section. It will cross with other grain sorghums if planted near them. Six pounds of seeds will plant an acre., Lb. 10c.

\section{SACCHARINE SORGHUMS}

Red Top or Sumac Cane-This is the most popular variety for our state, and the one is most generally planted. Seed is smaller than that of the Orange or Amber. Produces an immense quantity of fodder. Ib., 10c.

Early Orange-This variety has taller and heavier stalks than any variety of cane. It is not quite as early as the Early Amber, but is a better producer, and is better for syrup_making. Lb., 10c.

Early Amber-This is the earliest sort, and makes fine hay, which is relished by all stock. Lb., 10c.

Japanese Honey Drip-Known in some sections as Japanese Seeded Ribbon Cane. It makes an unusually large stalk, sometimes as large in diameter as Ribbon Cane and much taller. Yields as much as four to five hundred gallons of the very best syrup to the acre. Lb., 20c.

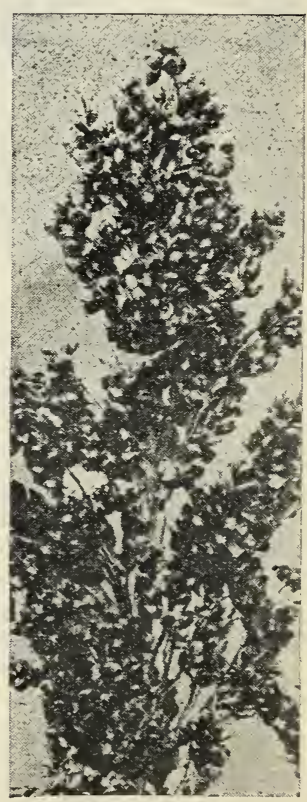

Honey Drip 


\section{POULTRY REMEDIES}

SPECIAL DISCOUNT-On all orders of poultry and stock remedies amounting to $\$ 5.00$ or more we will allow you a $10 \%$ discount. On orders of $\$ 10.00$ or more we will allow you a $15 \%$ discount. Order your present and future requirements at one time and save money.

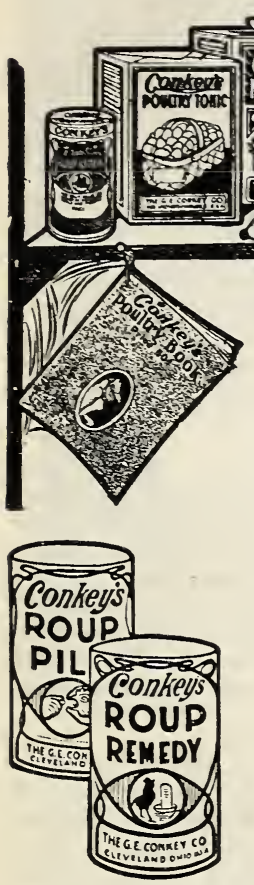

\section{CONKEY'S POULTRY REMEDIES}

Your money cheerfully refunded if any Conkey remedy does not satisfy. Conkey's Poultry Book Free if you call at our store or mailed for $6 \mathrm{c}$ in stamps to cover postage for mailing.

Conkeys Sorehead Remedy

Pkg., 25c-50c.

Conkeys Roup Remedy

Pkg., 25c-50c-\$1.00

Conkeys Roup Pills

Pkg., 25c-50c-\$1.00

Conkeys White Diarrhea Remedy

Pkg., 30c-60c-\$1.20

Conkeys Cholera Remedy

Pkg., 25c-50c-\$1.00

Conkeys Canker and Bronchitis Remedy ............................................... 50c

Conkeys Limberneck Remedy ........................................................... 50c

Conkeys Rheumatic Remedy ..................................................................... 50c

Conkeys Blackhead Remedy

Pkg., 50c

Conkeys Poultry Worm Remedy

Pkg., 25c-50c

Conkeys Poultry Conditioner ................................................................... 25c

Conkeys Poultry Laxative ................................................................. Pkg., 25c

Conkeys Scaly Leg Remedy ............................................................Pkg., 25c

Conkeys Gape Remedy

Pkg., 25c

Conkeys Head Lice Ointment

Pkg., 10c-25c

Conkeys Lice Fix

Conkeys Flea Salve

Pkg., 25c-50c

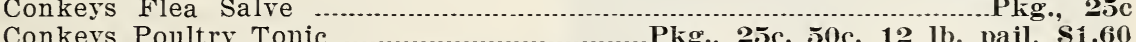

Conkeys Nox-i_cide (Dip and Disinfectant) Pt., 50c; Qt., 80c; 1́2 Gal. \$1.30; Gallon \$2.00.

\section{DR. LeGEAR POULTRY and STOCK REMEDIES}

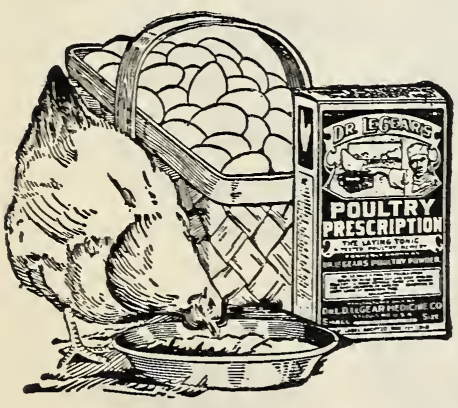

IE GEARS POULTRY PRESCRIPTION

Helps to make hens lay and to keep poultry healthy. A good general Tonic and Remedy for many ailments of poultry. It is especially beneficial during the Molt, in the breeding season and during the winter time.

Put up in 25c, 50c, and \$1.20 packages, $\$ 3.00$ pails.

\section{OR. LeGEAR'S DIP AND DISINFECTANT}

An excellent Antiseptic, Disinfectant, Germicide and Deodorant for both home and stable use. Good for Lice, Fleas, Sheep Scab and many forms of Ticks, Itch and Mange on Horses, Cattle, Hogs, Sheep, Goats, Dogs and Poultry.

Put up in quart, F0c; half gallon, s1.15:

\section{Fa one gallon, $\mathbf{8 1 . 8 0}$.}

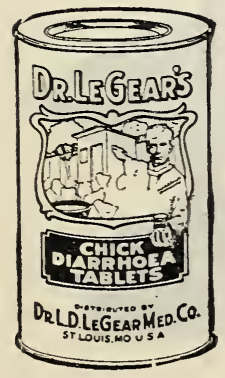

Special-Bring in your empty cans and let us fill it with LeGears Dip and Disinfectant at $\$ 1.25$ per gallon.

Dr. LeGear's Stock Powder ............25c, 50c and $\$ 3.00$ pails.

Dr. LeGear's Hog Prescription. 3 3,4 ib. pkg., 50c; 25 lb. pail, 83.00 .

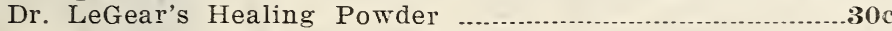

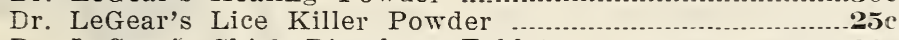

Dr. LeGear's Chick Diarrhoea Tablets

Dr. LeGear's Sorehead Remedy

Dr. LeGear's Poultry Bowel Regulator

Dr. LeGear's Gall Remedy

Dr. LeGear's Worm Powder

Dr. LeGear's Heave Remedy

Dr. LeGear's Poultry Worm Pills
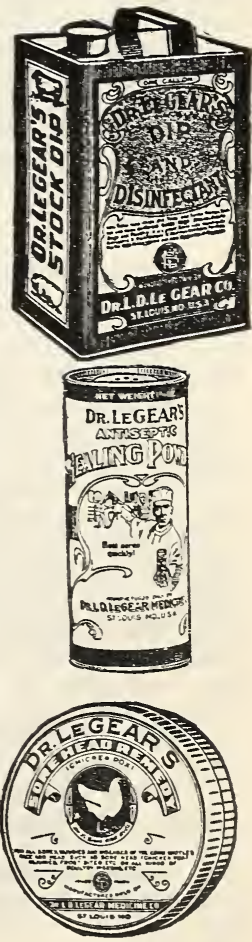


\section{GRASS SEED}

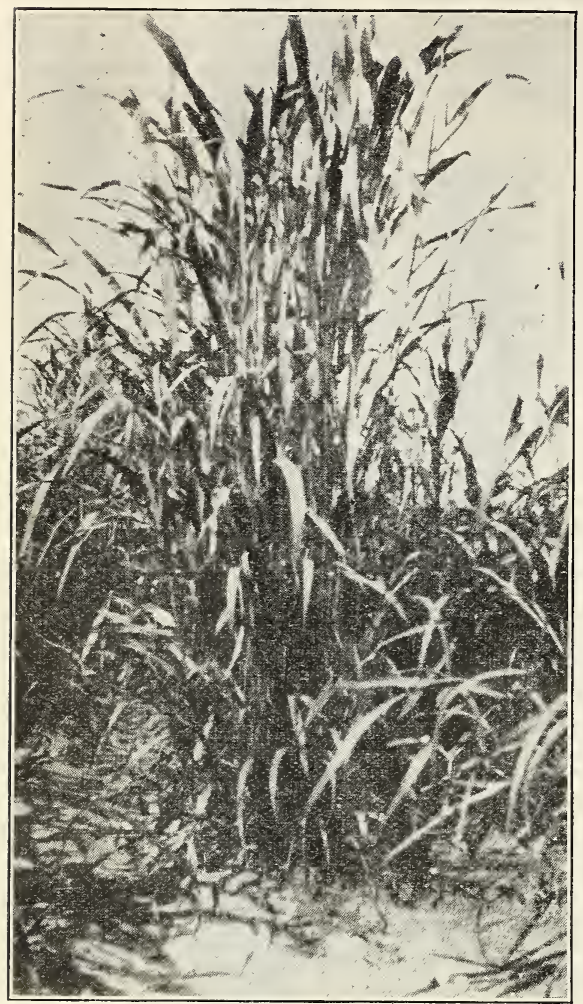

Sudan Grass

Sudan Grass-The great hay and forage crop. This wonderful new grass seerns to be taking the country by storm. This grass has been grown very extensively in Texas the past season and has been tested out in a number of other states and the verdict is unanimous everywhere it has been grown it spells success. It seems to grow successfully on all kinds of land, stands dry weather and does not blight under ample rainfall. Sudan Grass is thought to be the original wild form of the cultivated sorghums. It is an annual, the seed having to be sown every year. It looks very much like Johnson Grass when growing but has a different root growth. Johnson Grass reproduces itself from underground root stalks as well as from the seed. Sudan Grass will not sprout from the roots after frost has killed the plant. Ranges in height from five to ten feet, stems small and somewhat more leafy than Johnson Grass. Like the sorghum crops, it must be planted each spring and dies when the frost comes. Lb., $15 c$.

Rhodes Grass-A substantial grass of African origin and introduced into the United States a short time ago. Has proven since then as one of the best species for pasture or dry soil and is of great agricultural importance. It is a perennial sort which does not spread by underground rootstocks, but produces running branches which root at the joints, thereby producing new plants. It grows from three to four feet high, with a large number of very long, narrow and tender leaves. Lb., $\mathbf{7 5 c}$

Bermuda Grass-Almost everybody living in this section of the country knows this grass. It is planted as a lawn grass, and nothing will stand the sun better, or will make a prettier carpet, when kept short, than this grass. It is also very valuable as a pasture and hay grass, which therefore had to be propagated by the roots. Lb., 60c; 10 lbs., \$5.50.

English Rye Grass-Is largely sown by our landscape gardeners for winter lawns on Bermuda soil. The Bermuda blades being easily affected by frost, become red and rusty looking, while English Rye during winter presents a most beautiful appearance, being of a vivid green, and as the Bermuda during April and May makes its appearance it overgrows the English Rye, causing the latter to decay and act as a fertilizer to the existing grass. It should be sown from September to March at the rate of 3 to 4 bushels of seed per acre. 25 c $1 \%$.

\section{COW PEAS}

Whippoorwills - Has brown, speckled seed, easily gathered on account of the upright, bushy growth of the plants. The most generally planted pea on the market, being one of the earliest and best varieties on the market. Lb., 15c.

Blackeye-Grown extensively, as the dry peas find a ready market during the winter. The vines furnish excellent forage and produce large quantities. Lb., 15c.

Cream Peas-This is the most beautiful table Peas we have ever had the pleasure of offering our customers. It has given best satisfaction of any variety we have ever offered for table use, and very deservedly so, as there are none that can surpass it in splendid flavor. In point of yield they double the well known Blackeye, command a higher price on the market, cook quicker and are in every way superior to it as a table sort. It grows in bunch form. Peas are of a cream color. Lb., 15c.

Pink Beans-Grown extensively as a dry bean and finds a ready market. Lb., 15c.

Pinto Beans-Grown mostly for a dry bean but makes a good snap bean when the pod is young and green. Pods flat and tender. Lb., 15c.

Brown Crowder-An excellent bearer and vines make a splendid forage. Planted extensively as a dried pea. I.b., 15c.

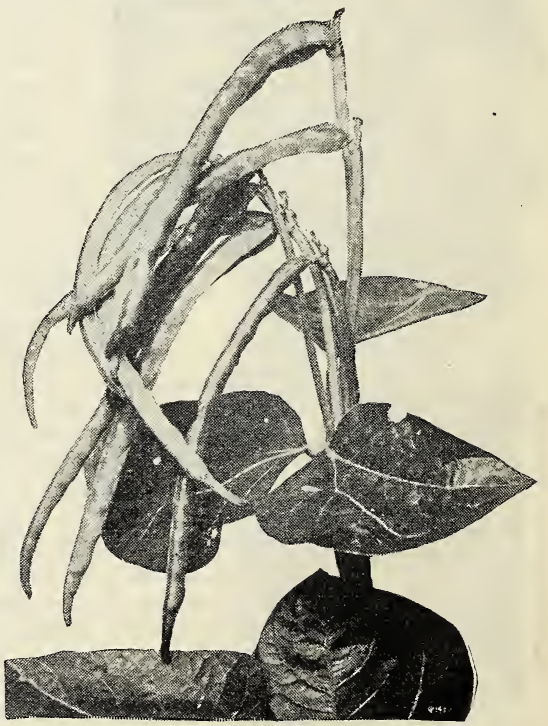

Cuw Peas 

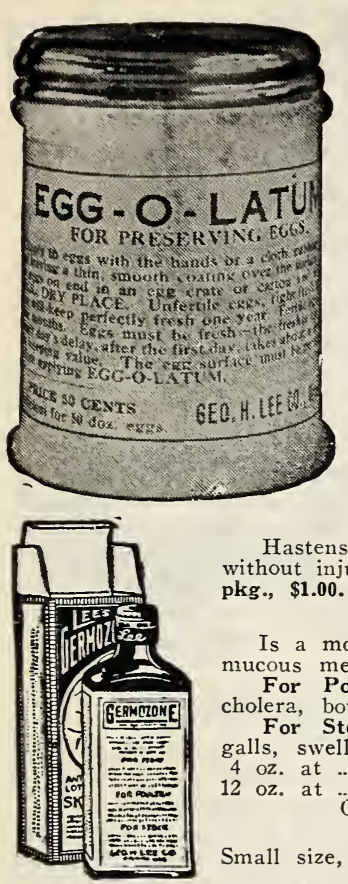

vithoutens the moult, tones up the system, stimulates the egg-producing organs pkg., $\$ 1.00$.

\section{GERMOZONE}

Is a most effective remedy for diseases affecting the skin and semi-exterior nucous membrance of man, fowl or beast.

For Poultry-Roup, colds, canker, chicken-pox, sore head, swelled head, cholera, bowel trouble, etc.

For Stock-Cuts, sores, wounds, sore eyes or mouth, saddle or harness galls, swelling, skin diseases, etc.

$\begin{array}{rrrr}4 & \text { oz. at } & \ldots \\ 12 & \text { oz. } & \text { at }\end{array}$

$$
\text { Gallon }
$$

$$
\text { GERMOZONE }
$$

Small size 20 MOZONE TABLETS (Mailable) LEES HEALING POWDER Splendid for cuts and sores on animals
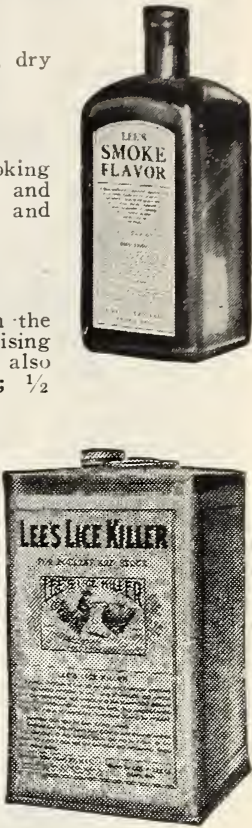

DR. HESS POULTRY AND STOCK

\section{PREPARATIONS}

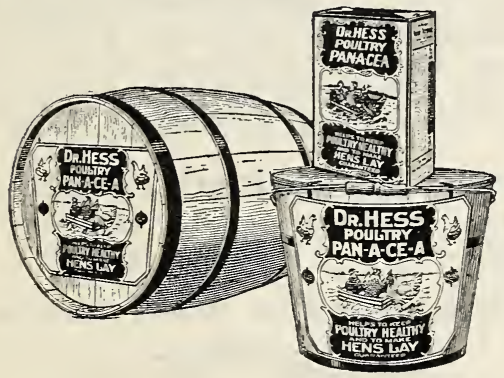

DR. HESS POULTRY PAN-A-CEA

Helps to make poultry healthy and to make hens lay. Not a stimulant, but a tonic that tones up the dormant egg organs, brings back the scratch and cackle, and compels each hen to put her share of eggs in the market basket. $1 \mathrm{x} / 2$ Lb. Pkg. 25c, 5 Lb. Pkg. 75c, 12 Lb. Pkg. \$1.50, 25 Lb. Pail $\$ 3.00$.

DR. HESS STOCK TONIC

By promoting health it makes hog raising, dairying, and stock feeding more profitable. Provides the most efficient, most economical, and least bothersome method of treating hogs for worms.

31/2 Lb. Pkg. 50c, 10 Lb. Pkg. \$1.25, 25 Lb. Pail $\$ 3.00$.

\section{Pratts, poultry regulator}

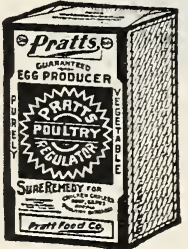

Used by most successful poultrymen all over the world, for over 50 years. It is not a dope or stimulant but furnishes the necessary health and egg making elements that feeds lack. It makes healthier hens, more eggs, shortens the moult, increases growth, aids digestion, regulates the bowels and keeps your fowls toned $u p$ and pro ducing.

$25 \mathrm{c}$ and $50 \mathrm{c}$

\section{Pratts,}

\section{COW TONIC}

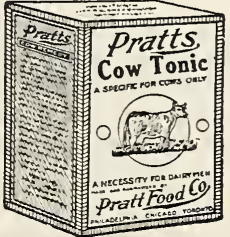

This splendid tonic is made spec ially for cows. It contains no filler and no antimony, arsenic or dang erous minerals. Mixed with the feed it helps the digestion, regulates the bowls, tones up the reproductive system, helps prevent abortion, costs little and pays you big profits. Absolutely guaranteed. Try it. 50c.

\section{PRATTS BAG OINTMENT 50c}

DR. HESS ROUP TABLETS

For Roup, Diptheria, Chicken Pox, Canker and all catarrhal diseases in poultry. Given in the drinking water. It is antiseptic, slightly astringent, non-irritating.

100 Tablets

$56 \mathrm{cts}$ 


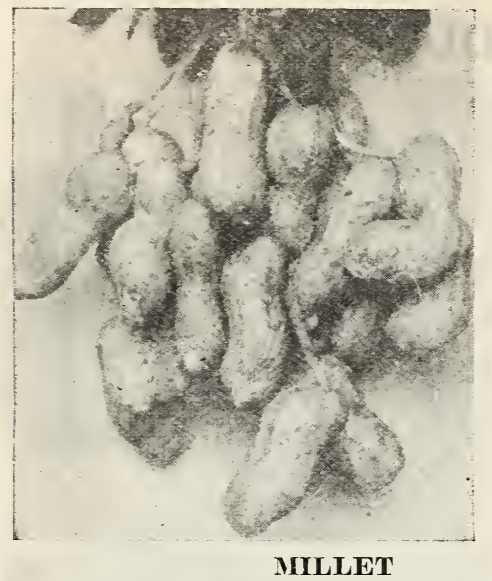

Fancy Big German-The most popular of all the Millet for hay or seed. It matures in six to eight weeks after planting. If wanted for hay, it should be cut while in bloom, as the hay quality decreases as soon as the seed hardens in the head. Our variety of Millet is the best and you will find it superior to any variety. Lb., 15c.

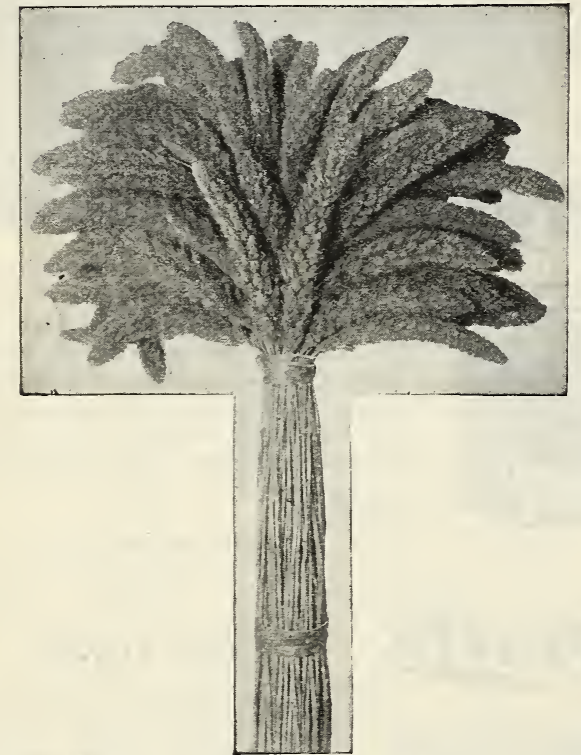

Hog Millet-The seed is large for a Millet and makes a rich food. Good for hogs or chickens. The seed ripens while the stem is yet green, so that if cut promptly you can get a crop of seed and also one of fodder or ensilage. Lb., 15c.

\section{RAPE SEED}

One of the best forage crops on the market, making excellent feed for hogs, sheep, cattle and poultry. Very similar to Collard greens, and may be cooked and eaten like Collards. Sow at the rate of three pounds to the acre.

Dwarf Essex-This is considered the most desirable variety of Rape, and should be planted on every farm and in every garden. Furnishes rich, nutritious pasture and green feed six to seven weeks after planting. Lb., 25c.

\section{PEANUTS}

Spanish-The earliest variety grown, pods are small, but ably well filled and solid, and the yield per acre is ery large. Can be cultivated with the plow. Because of its early habit and easy cultivation it is best variety to grow The nuts proper grow in fine variety worthy of the highest recommendation.

\section{SUNFLOWER}

Mammoth Russian-Produces very l a rg e heads sometimes 15 inches across. The seeds are valued very highly as a feed for poultry. The seed can be planted on a waste piece of ground any time in the early spring and until the middle of July. Should be sown at the rate of about three pounds to the acre. $\mathbf{L b}$., 20c.

\section{PARADICHLOROBENZOL}

(P. D. B.) A friend to the farmer and seedman who has been troubled with weevil. It is taking place of Carbon Bisulphide (High Life) as it lasts longer and no danger of fire. One ounce placed in a barrel of grain will do more good than 25c High Life. Every farmer should have a few pounds of P. D. B. handy when putting away his planting seed for the next season.

This white powder (P. D. B.) is recommended by the Department of Agriculture, Bulletin 1246, to combat borers around the base of trees. Use $1 / 2 \mathrm{oz}$, for one year old, $1 / 2$ to $1 \mathrm{oz}$., for 3 to 5 year old and 1 to $1 \frac{1 / 2}{2}$ ozs., for 6 year old trees. To apply, dig 3 inch trench around tree about 3 inches from the tree. Place (P. D. B.) in trench and cover with soil. This is not poisonous to human, but will kill insects. $1 / 4$ lb., 20c; 1/2 lb., 35c; lb., 60c.

\section{CARBON BISULPHIDE}

Carbon Bisulphide-(High Life)-Used for ants and weevils. Pts. 50c; Qts. 90c; Gallon $\$ 2.25$.

\section{MARTIN SCREW WORM KILLER}

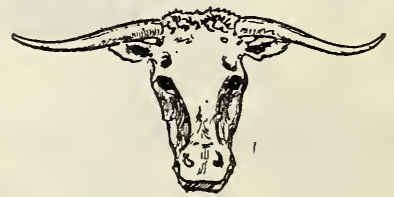

Martin's Screw Worm Killer--Kills the worms quickly without any bad effects on the wound and assists as a fly repellant. $2 \frac{1 / 2}{o z}$. bottle, 25c.

\section{SALT - SALT}

25 Lb. sks Fine Salt, 35c each.

$100 \mathrm{Lbs}$. sks Fine Salt, \$1.10 each, \$20.00 per ton.

100 Lbs. sks Stock Salt, 90c each, \$17.00 per ton.

50 Lb. Blocks Sulphur Salt, 55̄c each, \$20.00 per ton.

50 Lb. Blocks Plain Salt, 45c each, \$16.00 per ton. 


\section{BURRELL-DUGGER REMEDIES}

SOLD UNDER POSITIVE MONEY BACK GUARANTEE IF NOT SATISFIED

\section{FOR CHICKEN LICE}

\section{U. S. Government recommends new chemical. Destroys even young lice as they hatch}

Poultry raisers need guess no longer as to the best method of getting rid of poultry lice. After many tests, the U. S. Department of Agriculture has found Sodium Flouride superior to any other preparation for this pur-

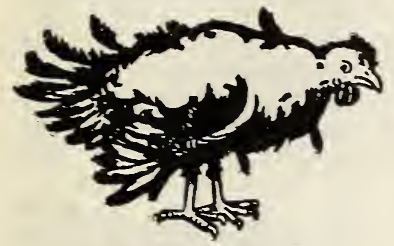

"I Need T. S. F." pose. They say it kill both old and young lice, including unhatched lice present at the time of treatment. Talcrimized Sodium Fluoride (called " $T$. $S$. F.'") is made especially for poultry use." It is less irritating than straight Sodium Fluorid e, penetrates the plumage more thoroughly, and comes packed in a moisture-proof. shaker-top package bearing the U. S. Government's directions for using. It is convenient -never cakes or loses strength-and always does the work. Full directions are on every can of T. S. F. for work. Full directions are on every can of methods. Prices-Small Size (for 50 chickens), $40 \mathrm{c}$; Large Size (twice the $40 \mathrm{c}$ size), 70c; Special Size (5 times $70 \mathrm{c}$ size), $\$ 2.65$. The above prices include packing and postage.

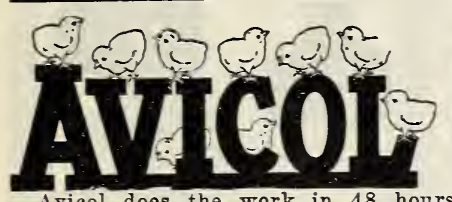

For W h it e Diarrhea in $\mathrm{C}$ h i c ks and Blackheads in Turkeys

Avicol does the work in 48 hours. Almost from the very moment you drop the first Avicol tablet in the drinking water, the sick chicks start to get well. Us. ually, in a short time, the very ones that seemed too weak and sick to live another day, are running around as lively as crickets, full of pep, hungry, healthy, scratching and pushing for a place at the feeding trough. After a few days of Avicol treatment, it will be hard for you to tell just which chicks had been sick and dying. They will sll be as lively and active, the very picture of health.

Don't sit back and say your loss of baby chicks can't be stopped. It CAN BE STOPPED-easily, quickly, and at almost no expense. All jou need do is drop an Avicol tablet in the water occasionally. Avicol is a special bowel antiseptic. It stops disease and prevents its spread by destroying germ life and helping the chick withstand infection. Price, 50c; Special Large Size (almost 3 times 50c size), $\$ 1$.

We can promptly ship you any of these guaranteed remed

\section{JAHNKE'S ROUP REMEDY}

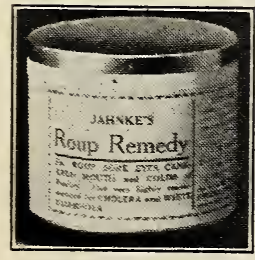

For roup, colds, cholera, white diarrhoea, etc. Placed in the drinking water, it kills the germs without any effort on your part. Does not color the drinking water. An established remedy which does its work quickly and efficiently. Don't let your chickens suffer and die. Separate the sick ones from the other's and treat vigorously. Full directions on box.

Per box

\section{DON SUNG}

CHINESE FOR EGG-IAYING

Makes hens lay in any weather

"Hens won't lay in Fall and Winter,"' used to be accepted as a fact. But any one who has tried Don Sung knows that hens will lay right through the zero spells of winter, and all other cold or wet seasons. Don Sung is not an ordinary stock or poultry powder. It is a concentrated medicine-no needless bulk or filler-ready to add to your mash feed. It has a direct tonic action on the egg-laying organs and doesn't force or hurt the hen in any way. It produces more eggs by first putting the hen in good health, and then helping to maintain that health.

Costs Nothing To Try

Every poultry raiser is invited to try Don Sung-at our risk. Separate 15 hens and give them Don Sung for one month. Then watch results. If Don Sung pass you, keep on with it. If you

don't think it has paid you, tell us and back comes your money. No arguments to it. Don Sung is guaranteedtry it, at our risk. Prices of Don Sung Tablets: Small Size, 50c; Large Size (3 times the 50c size), \$1; Special Size (6 times the $\$ 1$ size), $\$ 5$.

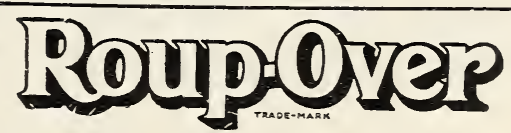

"The Over-Night Roup Remedy"

For Roup, Canker and Colds

Use Roup-Orer st the very first sympton of Roup or Colds in sour flock. It clears the air passages and brings relief with magic quickness. Easily u s ed, both for individual treat. ment and in the drinking water for flock prevention. Leading poultry raisers ererywhere now use RoupOver, the over-night roup remedy. It's so easy! So sure! There's no other remedy like it $-\mathrm{n}$ ot $\mathrm{h}$ in $\mathrm{g}$ "just as good." Have bottle ready to use when you need it. Price, $50 \mathrm{c}$; Large Size (3 times 50c
size), \$1.

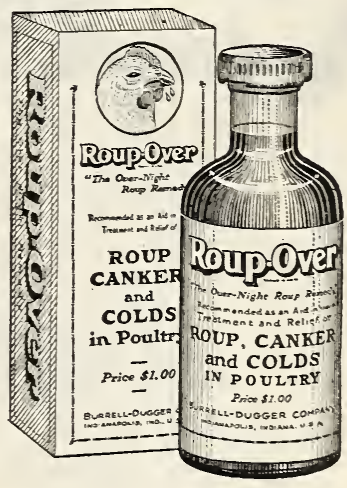

Write us to-day!

\section{KNOX-OUT}

$\mathrm{K}-\mathrm{O}$ is safe, clean and clear-contains no tar refuse, or heavy, dark oils. It has one hundred per cent efficiency and is highly

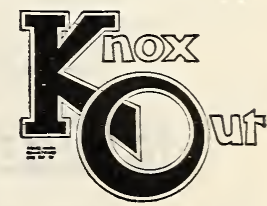

economical. The combination of strangling, repelling and other effects on the flies, enables $\mathrm{K}-\mathrm{O}$ to give the cows solid comfort and help maintain flesh and volume of milk. It gives you contented cows and help you save that $35 \%$ to $60 \%$ milk loss. It makes milking pleasant and comfortable for the herdsmen. Gallon 


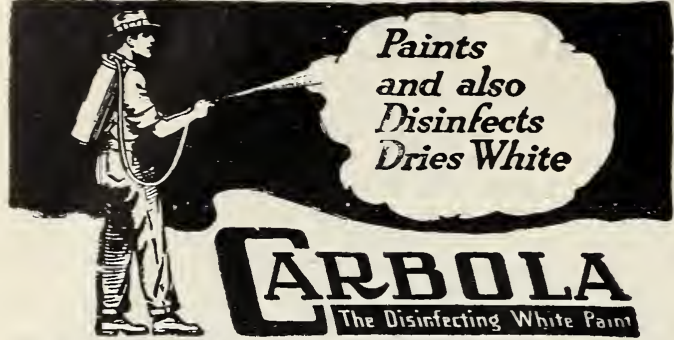

\section{THE POWDER OF MANY USES}

CARBOLA is a white paint and powerful disinfectant combined in powder form. It is ready to use as soon as it is mixed with water. It can be easily and quickly applied to building interiors with brush or spray pump. Disinfects and dries pure white. Does not flake or peel off. One pound covers $100 \mathrm{sq}$. ft.

CARBOLA makes buildings light, clean, sweetsmelling and sanitary. Helps to prevent contagious diseases among live stock and to keep poultry, cattle, horses, etc., free from lice, mites and other parasites. Recommended by leading agricultural colieges, experiment stations and health authorities for use in poultry houses, stables, dairies, hog pens, cellars, garages, dog kennels, rabbit hutches, factories, warehouses, outbuildings. on trees and tree trunks, and in the garden.
5 Lb., Pkg.
$85 \mathrm{c}$
10 Lb., Pkg.
$\$ 1.50$

50 Lb., Bag $\$ 5.50$

\section{2 PARASTIE REMOVER

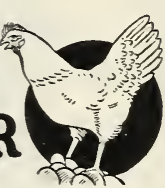

them of all blood sucking lice, mites, fleas. blue bugs, clean them of all intestinal worms and parasites. It is also a wonderful poultry tonic, blood purifier, health builder and egg producer. It contains lots of sulphur, compounded scientifically with other health building ingredients. Known remedies for preventing disease. "Prevention is cheaper than cure." Keep your flock free of insects and intestinal worms and their system in good condition through the winter and you will get good hatchings and strong chicks in the spring. A supply to last through the winter and spring will cost very little. Give it a six days trial at our risk. Money back if not pleased. 50c and $\$ 1.00$ bottle, not postpaid.

\section{(2) 教 FOR BLUE BUGS}

\section{MARTIN'S POULTRY TONE}

Martin's Poultry Tone Is a Tonic to be fed to Poultry that have been exposed to blood sucking insects. Poultry that have been exposed to blood sucking insects show a loss in vitality, and in some cases the vitality of the fowl is reduced to where they become weak and in some instances can not walk. Martin's Poultry Tone is to be mixed in bran or dry mash as per directions on package. 1 Lb. Pkg. 50c; 21/4 Lb. Pkg. \$1.00; 5 Lb. Pkg. \$1.75.

\section{VACCINATION PAYS}

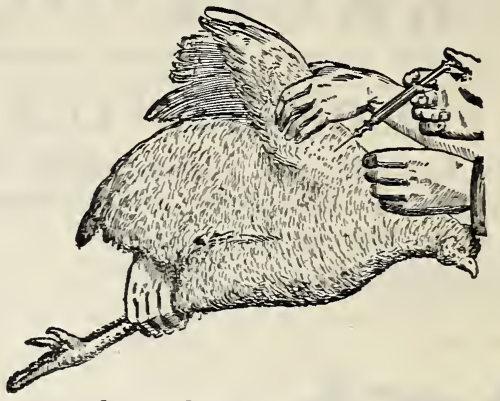

Stops poultry losses. Increases profits. Best preventative and treatment of mixed infections in poultry, including diphtheria, roup, colds, canker, cholera and their complications.

Vaccinate with Avian Mixed Infection Bacterin

60 doses

$\$ 2.00$

250 doses

5.00

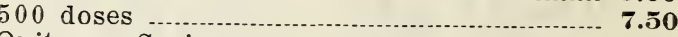

Quitman Syringe ............................................

10-dose Glass Syringe................................ 1.25
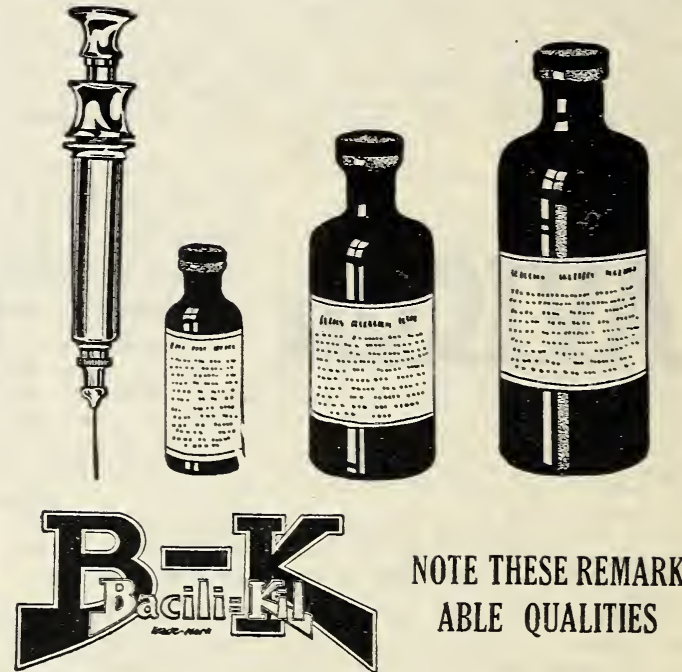

Powerful. By Government Method of test B-K has over ten times greater germ-killing strength than carbolic acid. Much stronger than coal tar disinfectants-much safer.

Safe. B-K is colorless, leaves no stain on floors, walls or utensils. Does not soil animal's hair.

Deodorant. B-K destroys foul odors -leaves no odor of itself.

Cheap to Use. B-K is so strong that much water is used in diluting. One gal. B-K makes 200 to 500 gals, of dilustion ready for use according to the

purpose.

Stops and cures Roup, Canker, Scaly Legs, Bumblefloot, Chicken Pox. Black Head in Turkeys and other contagious poultry diseases. FOR YOUR SHOW BIRDS

B-K removes all stains-keeps plumage, skins and combs clean and bright-destroys nits and eggs of lice. Keeps the flock healthy and snappy.

Greatest Household Purifier, Cleanser, Deodorant, Germ Destroyer.

Non-Poisonous, Colorless, Leaves no Odor.

Circular on request.

Trial size, 60c; quart, $\$ 1.25$; gallon, $\$ 3.00 ; 5$ gallons, $\$ 12.50$. Express only. 


\section{POULTRY AND STOCK FEEDS}
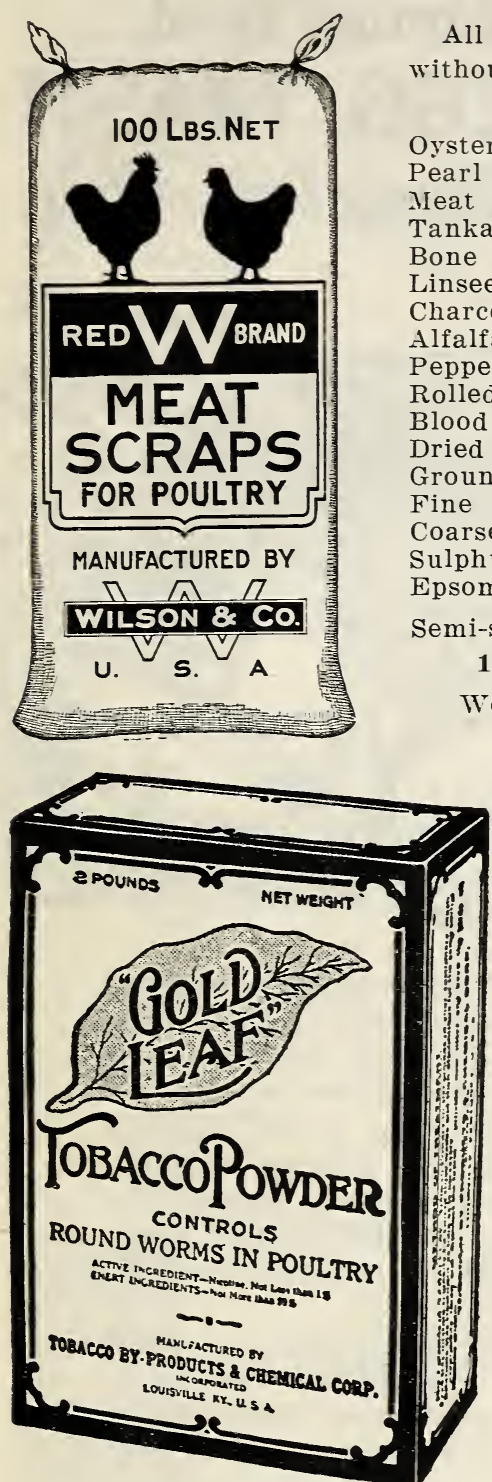

All prices quoted f. o. b. San Antonio, Texas, and subject to change without notice.

\begin{tabular}{|c|c|c|c|}
\hline & $\mathrm{Lb}$ & $25 \mathrm{Lb}$. & \\
\hline Oyster Shell (Reef Brand) fine and coarse ....\$ & $.021 / 2$ & s.50 & \& 1.25 \\
\hline Pearl Grit, fine and coarse & $.021 \%$ & .50 & 1.50 \\
\hline 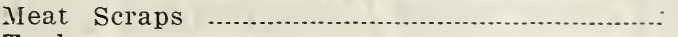 & .06 & 1.25 & 4.75 \\
\hline Tankage ...... & .06 & 1.25 & 4.50 \\
\hline Bone Meal .... & 0.5 & 1.10 & 4.00 \\
\hline Linseed Meal & .05 & 1.10 & 4.00 \\
\hline arcoal, fine and medium ..... & .05 & 1.00 & 3.50 \\
\hline Alfalfa. Meal, Triple XXX Pea Green ............... & .04 & .85 & 2.50 \\
\hline Pepper Seed & .05 & 1.10 & 4.00 \\
\hline Rolled Oatmeal & .06 & 1.25 & 4.50 \\
\hline Blood Neal …...... & .08 & 1.75 & 6.00 \\
\hline Dried Buttermilk & .15 & 3.25 & 12.50 \\
\hline ound Oats Groats ...... & .06 & 1.25 & 4.50 \\
\hline e Ground Oats .... & .04 & .75 & 2.50 \\
\hline rse Ground Oats & .04 & .75 & 2.40 \\
\hline & .10 & 1.75 & 5.00 \\
\hline & .10 & & 5.50 \\
\hline
\end{tabular}

Semi-solid Buttermilk. $1 / 4$ bbl. per lb. $7 \mathrm{c}$; $1 / 2$ bbl. per lb. 61/2c; 1 bbl. per lb. 6c.

We do not ship less than $1 / 4$ barrel of Semi-solid Buttermilk.

STRAIGHT FEEDS

Straight Feeds-For the benefit of our customers who mix their own feeds, we carry a full line of straight feeds. Cotton Seed Meal, Alfalfa Meal, Unbolted Meal, Shorts, Wheat Bran, Corn Bran, Rice Bran, Yellow Corn Chops, Ground Oats, etc. Owing to market changes we cannot quote prices in this catalog, and will be pleased to send prices on request.

G o l d L e a f Tobacco Powder - Controls round worms in poultry. 2 lbs., 30c; 10 lbs., \$1.00; 100 lbs., \$7.50.

Walko - Especially valuable for white diarrhea a $\mathrm{m}$ o $\mathrm{ng}$ incubator chicks. Tends to increase strength and vitality and should be given in drinking water as a preventive from the time chicks are out of the shell. 50c and \$1.00 pkgs.

NUX VOMLA-35c 1 b.

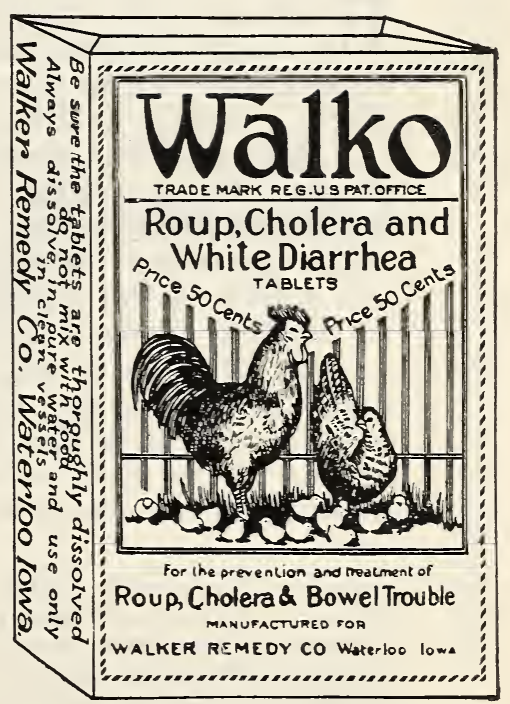

\section{CARBOLINEUM}

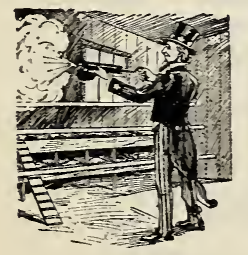

is a pure, unadulterated high boiling anthracene oil-a carbolineum of the highest grade-meeting Uncle Sam's requirements in every respect and it is

\section{SURE DEATH TO MITES AND BLUE BUGS}

Can be applied with a brush, like paint, or sprayed on as preferred One application will do the work. It should not be applied to the chickens. One gallon will go over an ordinary chicken-house, size $8 \times 12$. Comes in quarts, half gallons and gallons. Qts., 65c; 1/2 Gals., 90c; 1 Gallons \$1.50. Bring in Your Empty Cans and Let Us Fill It With Carbolineum at $\mathbf{8 1 . 2 5}$ Gallon. 


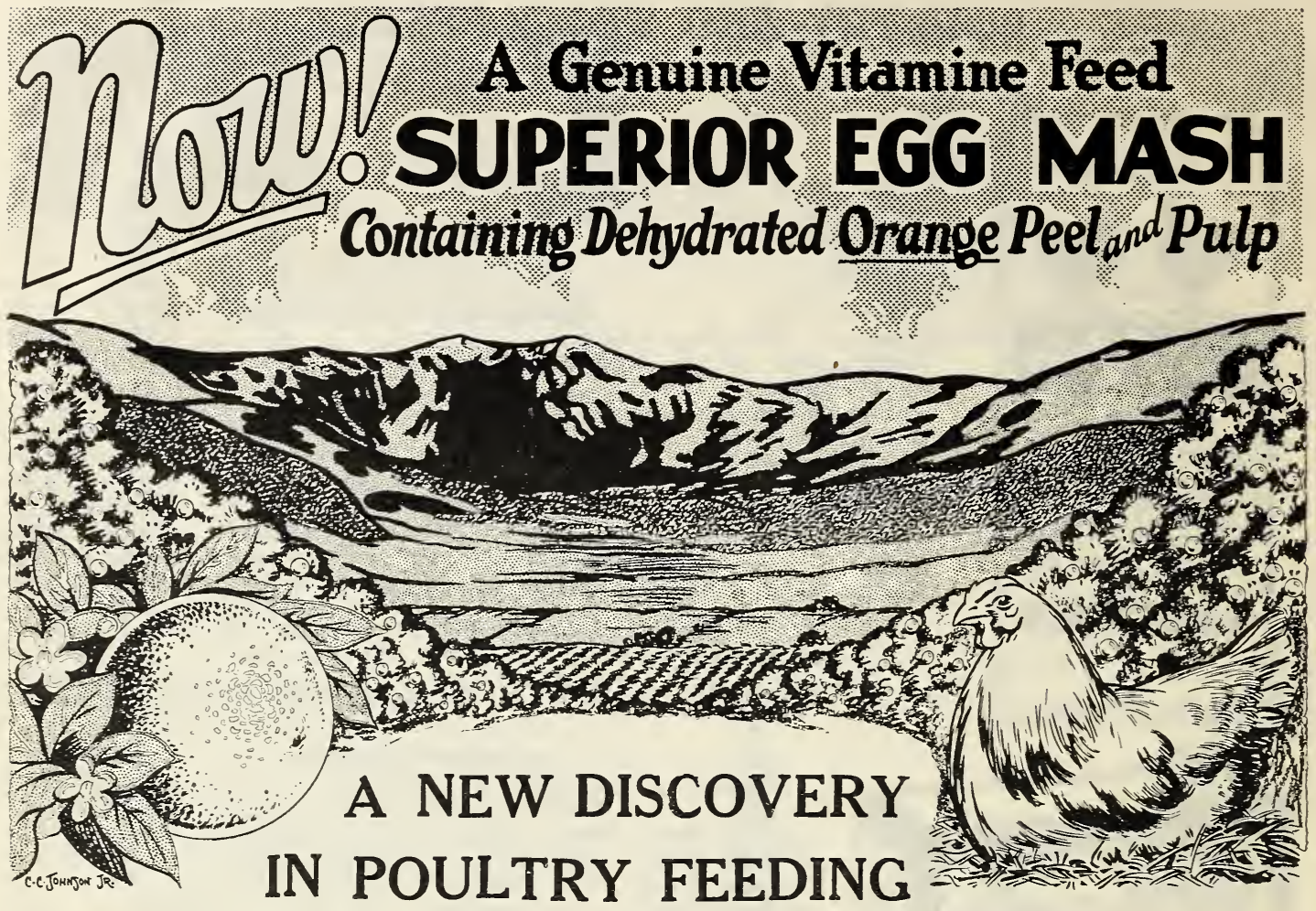

GVER since the discovery of the tremendous importance of vitamines

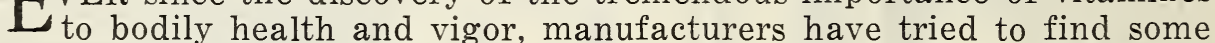
ingredients rich in vitamines which could be mixed with poultry feeds. Many ingredients have been tried, with varying degrees of success.

But now the Dehydrated Orange Peel and Pulp in SUPERIOR Poultry Feeds contains the vitamines necessary for poultry culture! And dehydration does not injure the vitamines or destroy any of the other necessary elements. When the chicken eats SUPERIOR Feed, the saliva in the digestive system quickly brings the orange back to its original freshness, juiciness and succulence.

In addition to vitamines, this new ingredient brings to your flock digestible minerals, acids and other valuable elements. Is it any wonder that it is the most perfect green food substitute, a preventive of coccidiosis and is causing SUPERIOR Feeds to become the most popular in the Southwest?

Superior Buttermilk Chick Starter Superior Buttermilk Growing Mash

Superior Buttermilk Egg Mash...

Superior Chick Scratch

Superior Growing Scratch

Superior Hen Scratch

Superior Chicken Fatner

Superior Superfat

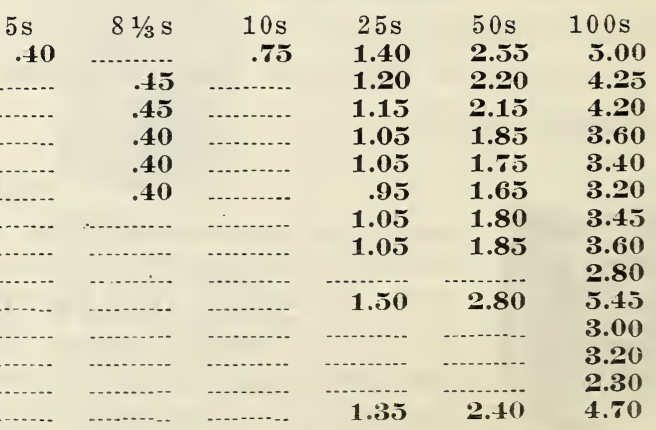

Superior Calf Meal

Superior Alcomo (Horse Feed) ....

Superior Pig Feed

Superior Moful

Superior Pigeon Feed

All Prices Quoted F. O. B. San Antonio, Subject to Market Changes Withour Notice And Stock Unsold. 


\section{CANARY BIRD and PARROT FEED AND SUPPLIES}

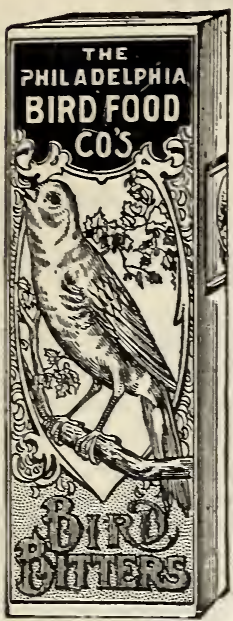

Mixed Canary Seed..S .15 lb. Composed of Hemp, Canary Rape and Millet.

Plain Canary Seed.- $\mathbf{. 1 5} \mathbf{~ l b .}$ Nixed Parrot Feed.. $\mathbf{. 1 5}$ lb.

Mixed Dove Feed.... .15 lb.

Hemp Seed ............ .10 lb.

Rape Seed .............. $\mathbf{. 1 5} \mathbf{~ l b . ~}$

Poppy Seed ............. .30 lb.

Siberian Millet Seed $\mathbf{. 1 0} \mathrm{Ib}$.

Sunflower Seed ...... $\mathbf{. 1 5} \mathbf{l b}$.

Cuttle Fish Bone.... $\mathbf{1 0 ~ o z . ~}$

Canada Peas ......... .10 lb.

Bird Manna ( 2 for $25 \mathrm{c})$........................ Mixed Parakeet Feed $\mathbf{. 1 5}$ lb. Red Gravel, small size .15 Red Gravel, large size .25 Silver Gravel, small size .15 Silver Gravel, large size $\mathbf{. 2 5}$ Mocking Bird Food.........40 Bird Bitters ...................25

Song Restorer

Mite Powder for birds.

Nesting Hair in boxes

.25

Nesting Food, box

Orange color food

Fish Food

\section{HALLERS BIRD REMEDIES}

Scaly Leg Oil ........................

Feather Restorer .....................25

Health Food .............................

Cuttle Bone \& Holder............10c

Song Restorer .....................25c

Bird Cage Wash ...............25c

Bird Bath .................................

Parrot Tonic ..................... 25c

Bird Nesting .........................

Mocking Bird Food ..............35c

Lice Powder ...........................

Bird Pie, 15c 2 for...............25c

Hemp \& Peppers ..................10c
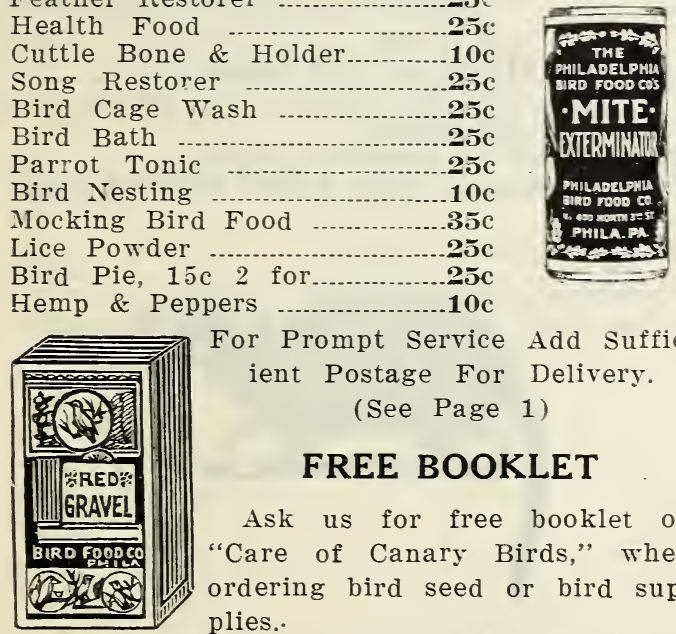

For Prompt Service Add Sufficient Postage For Delivery.

(See Page 1)

\section{FREE BOOKLET}

Ask us for free booklet on "Care of Canary Birds," when ordering bird seed or bird supplies.

\section{FOR THE DAIRYMAN}

Epsom Salts-Well known cathartic. Bowel regulator for stock and poultry. 1 lb., 10; 3 lbs., 25c; 14 lbs., \$1.00; 100 lbs., \$5.50.

Milk Bottle Caps-Will fit any standard milk bottle. 25c lb.; 10 lbs., \$2.25.

Butter Cartons 85c per 100, weight 3 lbs.; \$7.50 per 1,000, weight 30 lbs.

Butter Paper-For wrapping $1 \mathrm{lb}$., moulded butter. 35c 1b.; 3 lbs., $\mathbf{8 1 . 0 0 .}$

Flowered Sulphur-For feeding with salt etc. 1 lb., 10c; 10 lbs., 75c; 100 lbs., \$5.00.

\section{FREE DOG BOOK}

Polk Miller's famous book on the care, feeding and breeding of dogs will be sent free to all dog owners and dog lovers.

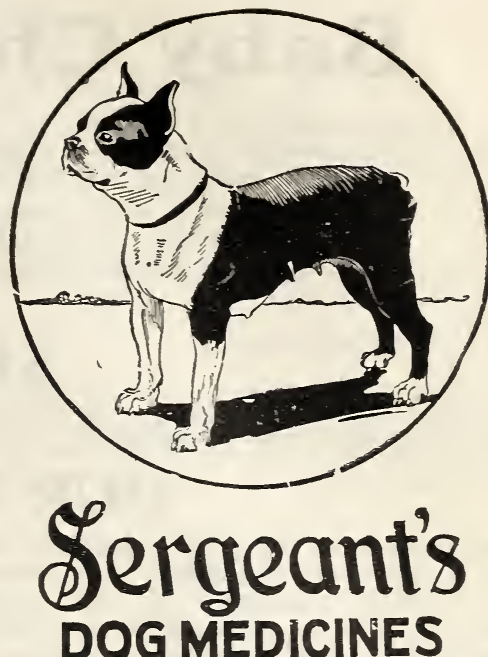

Run-Fit Medicine

Distemper Medicine

\$2.00

1.00

Mange Medicine

60

Condition Pills

Sure Shot Capsules for worms

Sure Shot Liquid, for worms

Tape Worm Medicine

Arsenic and Iron Pills

Canker Wash, for the ear

Well Mouth, for sore mouth

Pepsin Tablets, for indigestion

Diarrhoea Medicine

Cough Medicine, for colds

Rheumatic Pills

Dog Rub, a liniment

Eye Wash

Constipation Capsules

Carbolic Tar Soap

Skip Flea Soap, for fleas and lice

Skip Flea Powder

\section{CLAYTON'S DOG REMEDIES}

Kill Flea Powder

Kill Flea Soap

Ceoline Dog Soap

Condition Pills

Puppy Tonic

Distemperine

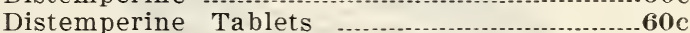

Worm Bullets

Worm Pills

Diarrhoea Tablets

Blood Pills

Vermifuge Capsules

Vermifuge Liquid

Tape Worm Expeller

Mange Medicine

\section{AUSTINS DOG BREAD}

A splendid con-

dit i o $\mathrm{n}$ er and ready prepared

fo od for the

D o g. Contains

ingredients in

such a combina-

tion as to make

a healthful, nou-

rishing dog food. Good for the teeth, for habits. 15c per lb.,; 2 lbs., $25 c$ : 25 lbs., \$2.50.
$60 \mathrm{c}$

35

$25 \mathrm{c}$

$60 \mathrm{c}$

$0 \mathrm{c}$

$0 \mathrm{c}$
$\mathrm{OC}$

$60 \mathrm{c}$

$60 \mathrm{c}$

$60 \mathrm{c}$

$60 \mathrm{c}$

$60 \mathrm{c}$

$60 \mathrm{c}$

$60 \mathrm{c}$

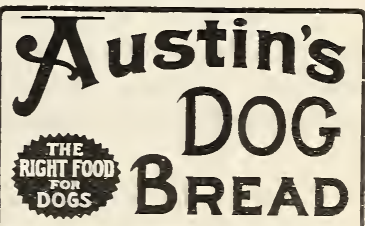

Good for the teeth, for 


\section{Baby Chicks By Mail}

At the solicitation of a number of our customers we have made arrangements to endeavor to supply WELL-BRED, DAY-OLD CHICKS to such of our friends who take a pride in their poultry and desire to build up quality and profit-producing flocks.

We will specialize in Baby Chicks furnished by

LORENZEN HATCHERY-BARBEE HATCHERY, ETC.

All eggs handled in hatchery come from large healthy flocks that are culled each year and are bred for high egg record.

\section{SHIPPING}

We will ship only sturdy healthy chicks in regular chick boxes Parcel Post or Express prepaid. Not less than 25 shipped. 1000 or more can be had on short notice at reduced price.

\section{OUR GUARANTEE}

We guarantee $100 \%$ live delivery within 60 hours travel of San Antonio, Texas.

All boxes must be opened in presence of the Post' Master or delivery clerk, they must certify in a written statement in what condition they found the chicks and how many dead ones.

We will not be responsible for chicks delivered by rural carriers. We will notify you in advance so you can arrange to receive your chicks.

All claims must be made within 24 hours after arrival of chicks.

\section{GRADES OF CHICKS}

\section{RHODE ISLAND REDS}

We grade our chicks of the heavy type at the following prices:

Grade A

$\$ 17.50$ per 100

\section{Grade B}

$\$ 15.00$ per 100
WHITE ROCKS

Grade C

$\$ 12.00$ per 100

Grade A being from pure bred egg producers that have been culled for years by experts.

Grade $B$ being from high grade utility flocks.

Grade $\mathrm{C}$ being from heavy mixed strains for broilers and fryers.

High egg producing White Leghorns and Anconas \$15.00 per 100 chicks

Write us promptly, stating breed, number of birds, and time of delivery desired, and we will take great pleasure in mailing back to you full information.

We will not attempt to meet a competition of mixed or low-grade chicks.

Remember-Your best interests can be served by ordering at least FOUR WEEKS in advance of shipping date.

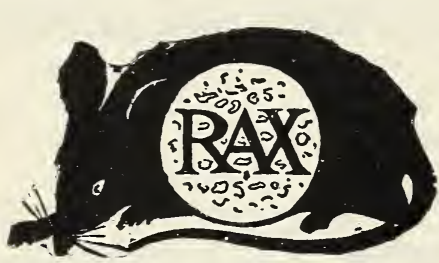

"Rax"-The scientific destroyer of Rats, Mice and all rodents. Harmless to human beings and all animals not rodents. $\mathbf{7 5 c}$ not postpaid.

\section{RAX IS NOT A POISON}

While it is absolutely deadly to rats and mice, it is harmless to human beings, domestic animals, poultry and birds. It may be used everywhere with complete safety.

\section{RAT-TOX}

Rat-Tox-A tasty bait and powerful poison out up in collapsible tube ready for use. 50c yer tube.

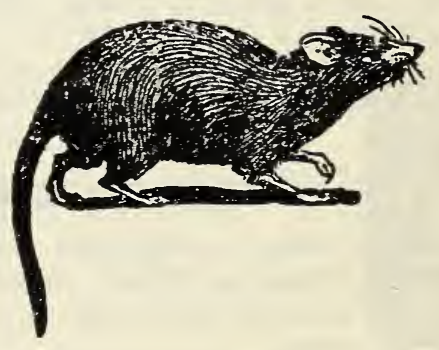

\section{RED SEAL RAT DEATH}

Red Seal Rat Death is not new or an experiment but has been successfully used in all work done by the International Exterminator Company who for 21 years have specialized in ridding institutions and large buildings of these pests. However, this is the first time it has been offered for sale to the home consumer and is filling a long felt want. It not only kills rats and mice but embalms and dries them up, thus leaving no odor. $\mathbf{2} \mathbf{o z}$. can, 50c; 8 oz. can, \$1.50. 


\section{ORDER SHEET \\ FUL ME OUT AND SEND ME IN TODAY TO \\ SATEX SEED COMPANY}

\section{For Better Seeds and Poultry Supplies}

529 S. Flores St.

San Antonio, Texas

Satex Seed Co., give no warranty, express or implied, as to description, quality, productiveness or any other matter of any seeds, bulbs, plants, or trees they send out, and will be in no way responsible for the crop. If the purchaser does not accept seed on these terms, they are at once to be returned.

\begin{tabular}{|c|c|}
\hline Your Name $\quad\left[\begin{array}{l}\text { Mr., Miss } \\
\text { Mrs. }\end{array}\right.$ & $\begin{array}{ll}\text { Date } & 192\end{array}$ \\
\hline $\begin{array}{l}\text { Street Address or } \\
\text { No. Rural Delivery } \\
\end{array}$ & $\begin{array}{c}\text { Amount Enclosed } \\
\text { P. O. Order } \$\end{array}$ \\
\hline Post Office & Postage Stamps \$ \\
\hline County & Draft or Check $\$$ \\
\hline Forward this Order by & Coin \\
\hline
\end{tabular}

\section{Station or Express Office}

(Only if different from P. O.)

Our Order No.

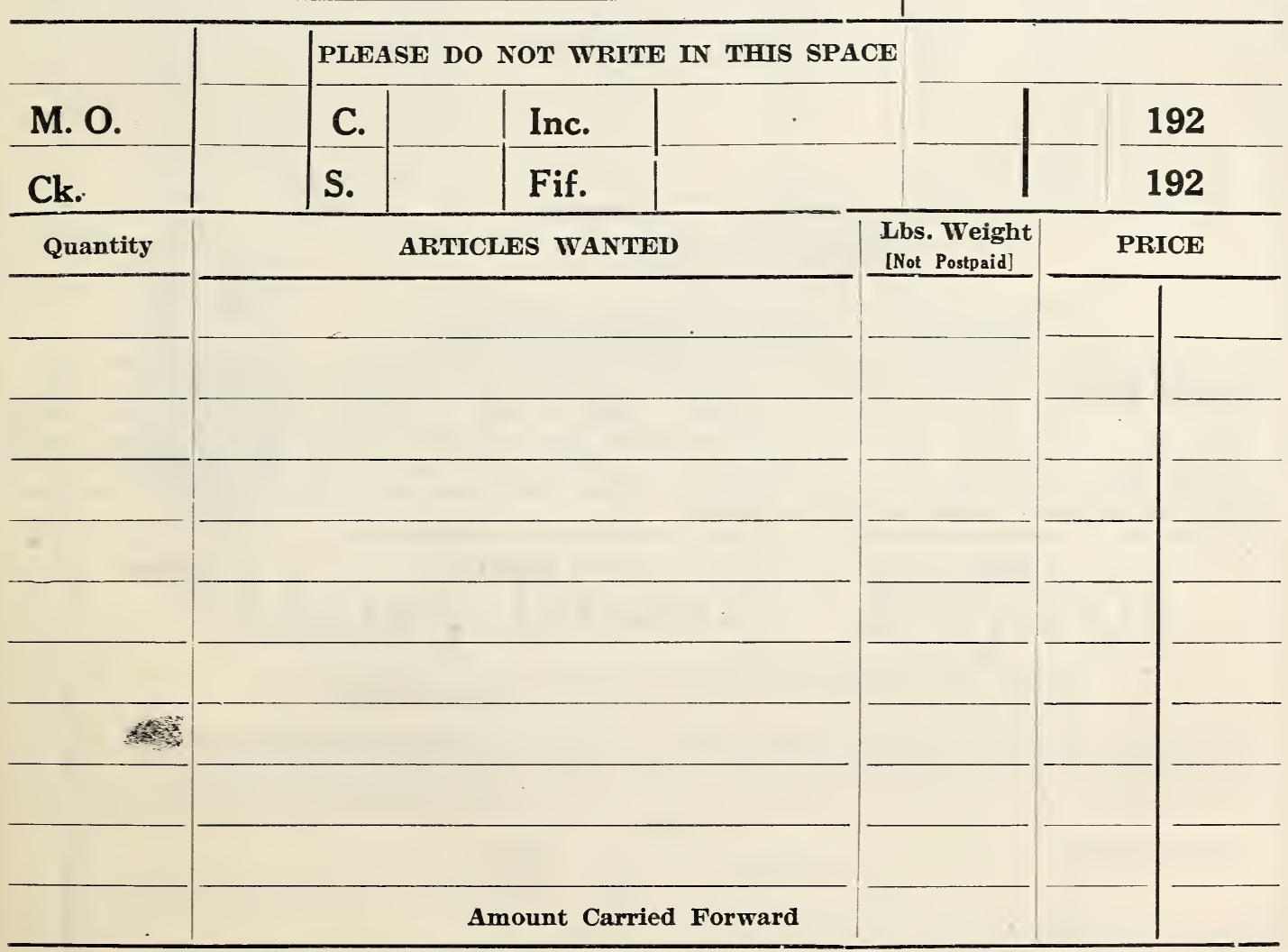




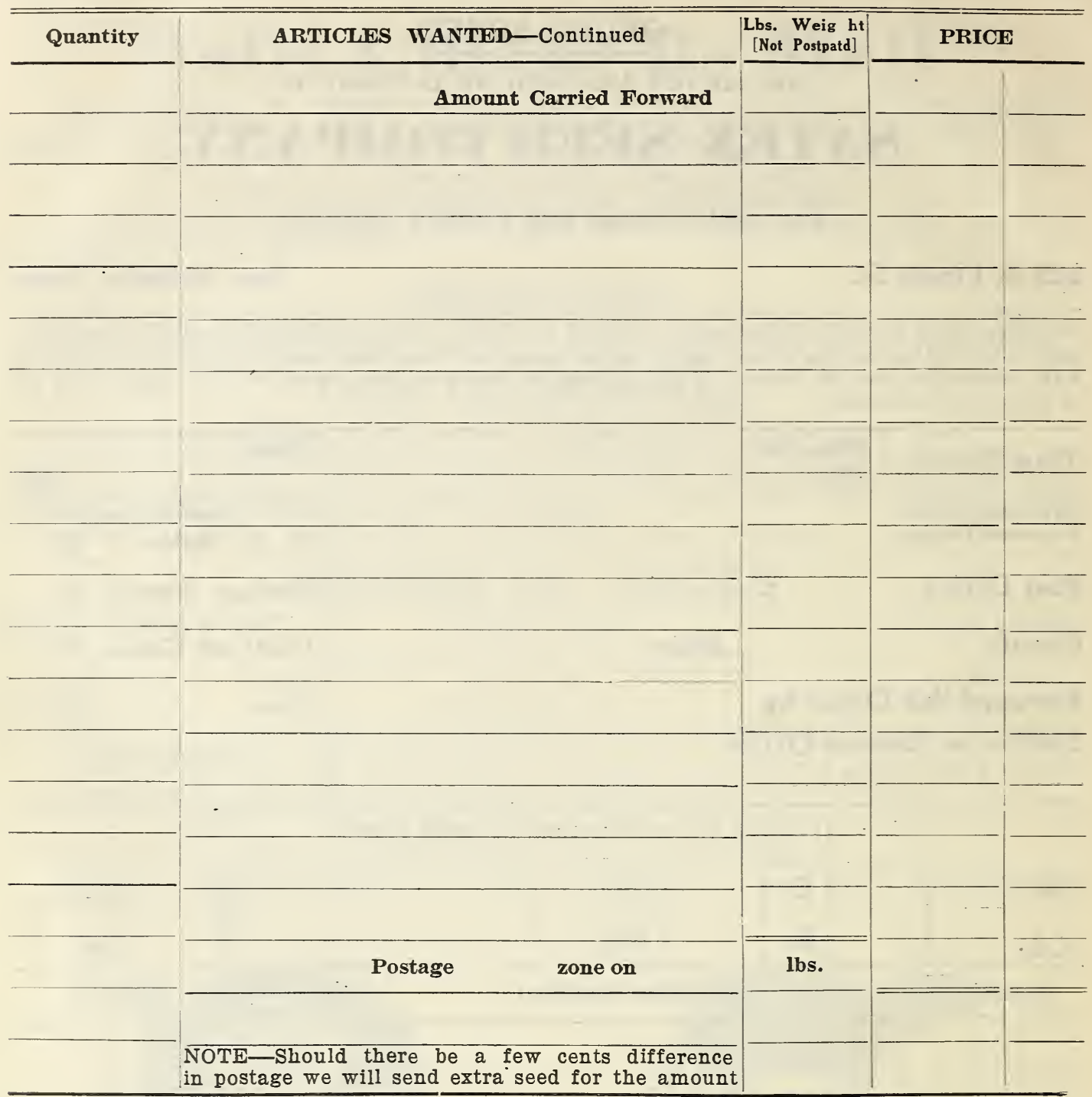

Special Offer Advertising costs a lot of money and we feel that our customers are entici. pecial Offer to it as much as any one. Send us your Order for garden or flower seeds amounting to One Dollar or more, and the name and address of five of your Friends who have gardens or poultry, and we will send you FREE, your own selection, twenty-five cents worth of garden or flower seeds in packages. This offer does not apply to Poultry Supplies, Bulbs, Fields Seeds, Plants or Garden Tools. 


\section{Garden Seeding Table}

\begin{tabular}{|c|c|c|c|c|c|c|}
\hline \multirow{2}{*}{$\begin{array}{l}\text { Name of } \\
\text { Vegetables }\end{array}$} & \multicolumn{2}{|c|}{ Seeds required for } & Distance & Plants & \multirow{2}{*}{\multicolumn{2}{|c|}{$\begin{array}{l}\text { Ready for use from } \\
\text { seed in about }\end{array}$}} \\
\hline & $100 \mathrm{ft}$. Row & One Acre & In Rows & Rows apart & & \\
\hline Artichoke .. & $1 \mathrm{oz}$ & $6 \mathrm{oz}$ & $2^{\circ} \mathrm{ft}$ & 3 to $4 \mathrm{ft}$. & 8 mont & hs \\
\hline Asparagus ... & $21 / 20 z$. & 4 lbs. & 1 to $2 \mathrm{ft}$. & 3 to $4 \mathrm{ft}$. & 3 to $4 \mathrm{y}$ & ears \\
\hline Beans, Bush. & $1 \mathrm{qt}$ & $11 / 4$ bush. & 6 in. & $2 \mathrm{ft}$. & 45 to & \\
\hline Beans, Pole & 1 qt. & 10 to 12 qts. & $3 \mathrm{ft}$. & $4 \mathrm{ft}$ & 65 to & \\
\hline Beet, Table. & $2 \mathrm{oz}$ & 5 lbs. & 4 in. & 1 to $1 \frac{1}{2} \mathrm{ft}$ & 60 to & $\because$ \\
\hline Beet, Mangel & $1 \mathrm{oz}$ & 5 lbs. & 8 in. & 2 to $21 / 2 \mathrm{ft}$. & 150 & “ \\
\hline Broccoli & $1 / 3 \quad$ Oz. & $2 \mathrm{Oz}$ & $2 \mathrm{ft}$ & $21 / 2 \mathrm{ft}$ & 120 & 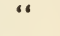 \\
\hline Brussels Spr & $1 / 3$ OZ. & $2 \mathrm{oz}$. & $2 \mathrm{ft}$. & $2 \mathrm{ft}$ & 100 to 120 & \\
\hline Cabbage, early. & $1 / 3$ oz. & $6 \mathrm{oz}$ & 18 in. & $21 / 2 \mathrm{ft}$. & 100 to 120 & $\because$ \\
\hline abbage, late... & $1 / 3$ oz. & $6 \mathrm{oz}$ & $21 / 2 \mathrm{ft}$. & $3 \mathrm{ft}$ & 125 to 180 & “6 \\
\hline Carrot .................. & $1 \mathrm{oz}$ & 3 to 4 lbs. & 4 in. & $11 / 2$ to $2 \mathrm{ft}$. & to 120 & “ \\
\hline Cauliflower & $1 / 3 \quad$ OZ. & $1 / 2 \quad 1 b$ & $2 \mathrm{ft}$ & $21 / 2 \mathrm{ft}$ & 100 to 135 & $\because$ \\
\hline Celery & $1 / 3$ oz. & $2 \mathrm{oz}$ & 6 in. & 3 to 4 ft. & 125 to 150 & 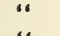 \\
\hline orn, Salad. & 3 oz. & & & 12 to 13 in. & 6 & “ \\
\hline Corn, Sweet & $1 / 2$ pt. 100 hills & 8 qts. & $3 \mathrm{ft}$. & $4 \mathrm{ft}$ & 65 to 100 & $“$ \\
\hline Cress ................ & $1 / 20 z$ & 2 to 3 lbs. & 1 in. & $1 \mathrm{ft}$ & 30 & 06 \\
\hline Cucumber .. & $1 \mathrm{oz}$ & 2 lbs. & $4 \mathrm{ft}$ & $4 \mathrm{ft}$ & 60 to 85 & $\because$ \\
\hline Egg Plant . & $1 / 3 \quad$ oz. & $4 \mathrm{oz}$ & $21 / 2 \mathrm{ft}$. & $3 \mathrm{ft}$. & 150 to 160 & 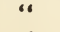 \\
\hline Endive ........ & $1 \mathrm{oz}$ & 4 lbs. & $1 \mathrm{ft}$ & $11 / 2 \mathrm{ft}$. & 50 to 75 & 6 \\
\hline ale & $1 / 3$ oz. & $2 \mathrm{Oz}$ & $2 \mathrm{ft}$. & $21 / 2$ & 100 to 120 & 6 \\
\hline Kohlrabi .. & $1 / 3$ oz. & $4 \mathrm{lbs}$. & 6 in. & $11 / 2$ & 75 & “ \\
\hline Leek ....... & $1 \mathrm{oz}$ & $4 \mathrm{lbs}$. & in. & $11 / 2$ & 120 to 160 & $\because 6$ \\
\hline tuce .... & $1 \mathrm{oz}$ & 3 lbs. & $1 \mathrm{ft}$. & $11 / 2 \mathrm{ft}$. & 65 to 100 & ‘ \\
\hline elons, Musk.. & $1 / 2 \quad$ oz. & 2 to 3 lbs. & $4 \mathrm{ft}$ & $5 \mathrm{ft}$. & 115 to 140 & c \\
\hline Melons, Water. & $1 \mathrm{oz}$ & $4 \mathrm{lbs}$ & $8 \mathrm{ft}$. & $8 \mathrm{ft}$. & 120 to 140 & “ \\
\hline Okra & $2 \mathrm{oz}$. & $10 \mathrm{lbs}$ & $11 / 2 \mathrm{ft}$. & $2 \mathrm{ft}$. & to 125 & “ \\
\hline Onion & $1 \mathrm{oz}$ & 5 to 6 lbs. & 3 in. & $1 \mathrm{ft}$. & 135 to 150 & “ \\
\hline Parsley .... & $1 / 20 z$. & 3 to $5 \mathrm{lbs}$. & 4 in. & $11 / 2$ & 10 & "6 \\
\hline Parsnip ... & $1 / 2$ oz. & 3 to $5 \mathrm{lbs}$. & 6 in. & $11 / 2 \mathrm{ft}$. & 125 to 150 & \\
\hline Peas & 1 to 2 pts. & 2 bush. & 2 in. & 2 to $4 \mathrm{ft}$. & 50 to 75 & $“$ \\
\hline pper .............. & $1 / 8 \quad$ oz. & $1 / 2 \mathrm{lb}$ & $2 \mathrm{ft}$. & $2 \mathrm{ft}$ & 140 to 150 & 6 \\
\hline Potato, cut . & $5 \mathrm{lbs}$. & 7 to 10 bush & $1 \mathrm{ft}$. & $21 / 2 \mathrm{ft}$. & 80 to 140 & $“$ \\
\hline mpkin ..... & 1 pkt. & $4 \mathrm{lbs}$ & $8 \mathrm{ft}$. & $8 \mathrm{ft}$ & 100 to 120 & \\
\hline 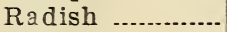 & $1 \mathrm{oz}$ & 8 to $10 \mathrm{lbs}$. & 2 to 4 in. & $11 / 2 \mathrm{ft}$. & 20 to 50 & “ \\
\hline sify .... & $1 \mathrm{oz}$ & $8 \mathrm{lbs}$ & 6 in. & $11 / 2$ & 125 to 150 & \\
\hline Spinach ...... & $1 \mathrm{oz}$ & $10 \mathrm{lbs}$. & 4 in. & $15 \mathrm{in}$. & 30 to & “ \\
\hline Squash, Bush... & $1 / 20 z$. & 4 lbs. & & $4 \mathrm{ft}$ & 60 to 75 & “ \\
\hline Squash, Lato... & $1 / 2$ oz. & 4 lbs. & $7 \mathrm{ft}$. & $8 \mathrm{ft}$. & 00 to 125 & “ \\
\hline nato ................. & $1 / 8$ oz. & 2 to $4 \mathrm{oz}$ & $4 \mathrm{f}$ & & 109 to 125 & \\
\hline Turnip ..... & $1 / 2$ oz. & 2 lbs. & $6 \mathrm{i}$ & $1 \mathrm{ft}$. & 60 to & “ \\
\hline
\end{tabular}

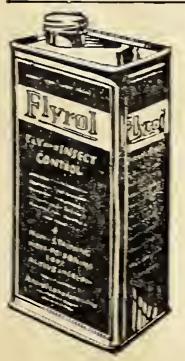

\section{FLYROL}

\section{A RELIABLE HOUSEHOLD INSECTICIDE}

Destroys flies, moths, mosquitoes, roaches, bedbugs, beetles, silverfish, fleas, chicken lice, mites and their eggs. Flyrol, sprayed thoroughly within the house is a sanitary measure insuring against contagion. Flyrol is $100 \%$ active and nonpoisonous. Will not stain the daintiest fabrics. No unpleasant odor. Use Flyrol freely during spring and summer months.

\section{PRICES}

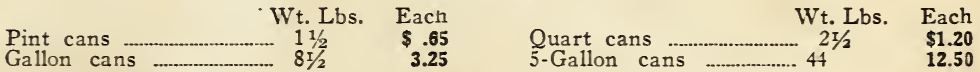

\section{"Dairy Brand" Flyrol}

A SPFCIAL OUTDOOR INSECTICIDE

For controlling flies, mosquitoes, chicken lice and fleas. A spray for dairy cows, horses and all farm stock. Especially effective for dairies, stables, barnyards, chicken houses, rabbit pens, dog kennels, trash piles and in swamps. These are the places that breed disease. Keep them clean by spraying Dairy. Brand Flyrol on them. Kills eggs and larvae.

PRICES

1/2-Gallon cans

Wt. Lbs. Each

5-gallon cans

Wt. Lbs. \$ $\$ .90$

1-Gallon cans

Wt. Lbs. Each

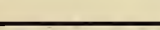




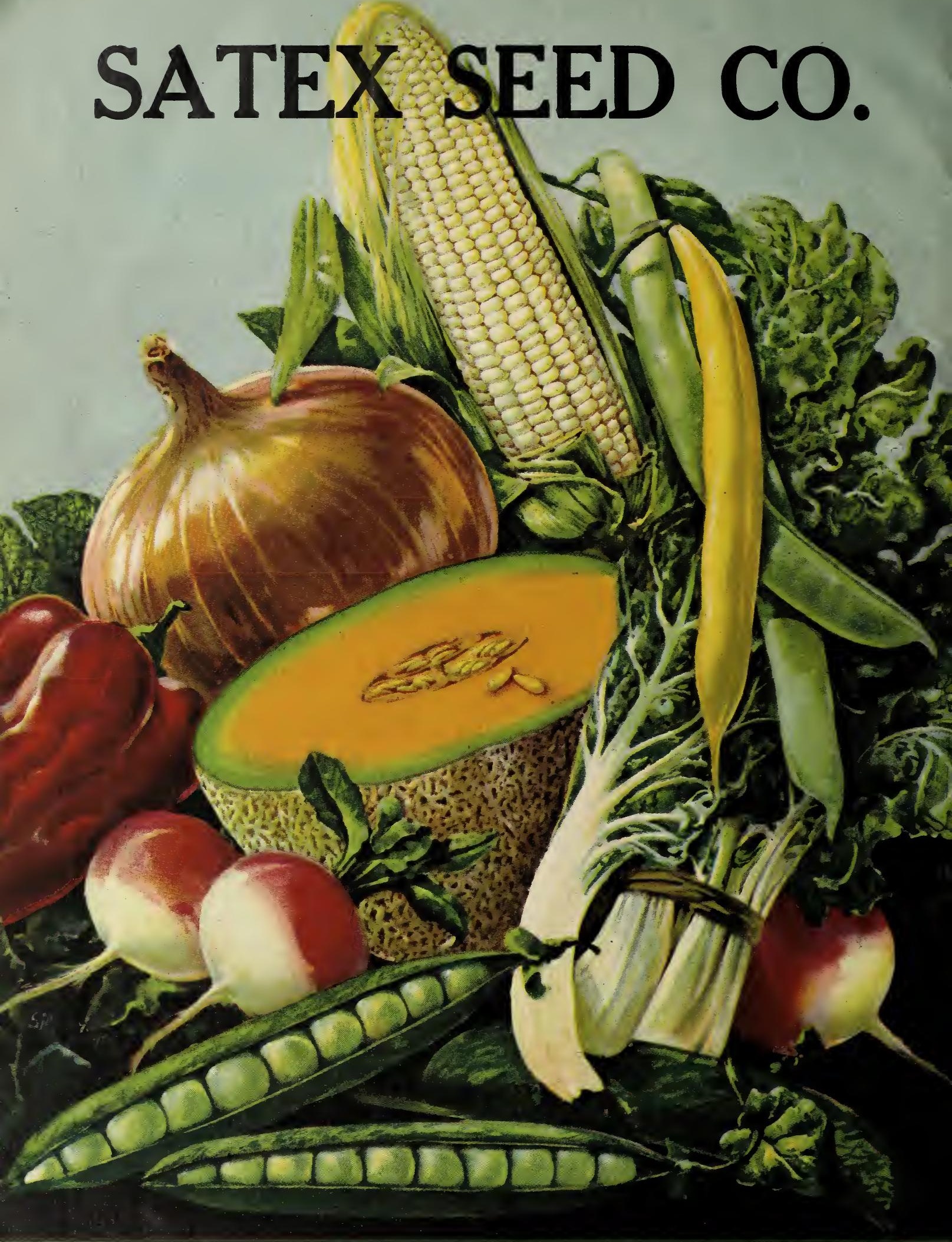

529 SOUTH FLORES STREET

BRANCH STORES

No. 2: 318 Fredericksburg Rd. . No. 3: 344 E. Commerce St.

\section{SAN ANTONIO, TEXAS}

